\title{
De positie van de niet-begeleide minderjarige vreemdeling binnen de hervorming van het Europees
} asielstelsel

\section{Caranina Colpaert LLM}

\section{Inleiding}

\section{Hoofdstuk I. Probleemstelling}

\section{Afdeling I. Onderwerp en stand van zaken}

1. Hervorming - De Europese Commissie lanceerde in 2016 zes voorstellen voor nieuwe wetgeving. ${ }^{\mathbf{1}}$ In het algemeen kunnen deze voorstellen tot hervorming ondergebracht worden in drie categorieën, die elk een eigen probleem behandelen. ${ }^{2}$ Een eerste probleem betreft het gebrek aan harmonisatie binnen de EU. De verschillen in asielprocedures en erkenningspercentages tussen de EU-lidstaten leiden tot fenomenen als 'asielshopping'. ${ }^{\mathbf{3}}$ Dit is een term die gebruikt wordt voor het verschijnsel dat verzoekers om internationale bescherming (hierna: asielzoekers) 4 hun aanvraag bij aankomst in Europa inhouden en verder trekken naar de lidstaat van hun voorkeur, zonder verkrijging van enig statuut. ${ }^{\mathbf{5}}$ Een tweede probleem is de gebrekkige implementatie van de Unieregelgeving door de lidstaten. ${ }^{6}$ Ten slotte bestaat er een fundamenteel probleem voor wat betreft de verdeling van de asielzoekers over de lidstaten. ${ }^{7}$

2. Externe focus - De huidige migratiepolitiek van de EU spitst zich voornamelijk toe op het externe beleid. ${ }^{\mathbf{8}}$ Dit houdt in dat de EU verschillende internationale akkoorden tracht te sluiten in verband met de bescherming van onder andere de Europese buitengrenzen. 9 Door deze wat eenzijdige focus wordt echter uit het oog verloren dat de individuele vreemdeling, wanneer die zich reeds in de EU bevindt, blootgesteld is aan verschillende risico's en nood heeft aan bescherming. ${ }^{10}$ Een specifieke categorie in deze risicozone is die van de NBMV. Net omdat de NBMV zeer kwetsbaar is, menen sommige auteurs dat aan de bescherming van de rechten van de NBMV nog wat gesleuteld moet worden. ${ }^{\mathbf{1 1}}$ De hervorming van het GEAS vormt dan ook een uitgelezen kans om de NBMV de aandacht te geven die hij verdient.

3. Intern gebrek aan focus - Toch lijken de EU-regelgevers deze kans niet te grijpen. Koffeman en Hillary wijzen erop dat verschillende voorstellen voor de nieuwe GEAS-wetgeving vanuit algemeen mensenrechtelijk oogpunt op zijn minst zorgwekkend zijn. ${ }^{12}$ De meest in het oog springende pijnpunten zijn de overdrachten binnen het Dublinsysteem, de vrijheidsbeperking en de vrijheidsontneming. ${ }^{13}$ Een bijzondere reden tot zorg betreft de positie van het kind en meer bepaald de positie van de NBMV. Critici wijzen daarbij voornamelijk op het verbod op foltering (art. 3 EVRM), het recht op vrijheid en veiligheid (art. 5 EVRM) en het belang van het kind. ${ }^{\mathbf{1 4}}$ Binnen de rechtsleer werd er echter, ook omwille van het recente karakter van de hervorming, nog niet bijzonder diep ingegaan op de mensenrechten van de NBMV binnen deze hervorming. Hoewel er verschillende studies rond de hervorming van het GEAS bestaan, ontbreekt een grondige analyse van de problematiek met betrekking tot de NBMV binnen dit systeem. ${ }^{15}$

\section{Afdeling II. Problematiek}

4. Wereldwijde problematiek - Wereldwijd richt de aandacht voor deze problematiek zich vooral op twee geografische centra: het Europese en het Amerikaanse continent. ${ }^{\mathbf{1 6}}$ In de eerste plaats hebben de Verenigde Staten te maken met grote aantallen NBMVs. ${ }^{17}$ Deze zoeken voornamelijk vanuit Zuid-Amerikaanse landen zoals Honduras, El Salvador, Venezuela en Mexico een toegang tot de V.S. ${ }^{\mathbf{1 8}}$ Daarnaast heeft ook de EU te kampen met een toestroom van NBMVs, die vooral vanuit Afghanistan en Eritrea in Europa terechtkomen. ${ }^{19}$ In 2015 betrof $20 \%$ van de toestroom aan asielzoekers in Europa niet-begeleide minderjarigen en in 2016 steeg dit percentage naar $35 \%{ }^{\mathbf{2 0}}$ In 2017 daalde de toestroom van NBMVs terug tot $15 \%{ }^{\mathbf{2 1}}$ Diverse partijen vrezen echter dat de afname het gevolg is van een versterkt optreden van de Libische kustwacht, of van de samenwerking van de EU-lidstaten met milities in Libië, waar asielzoekers in mensonwaardige omstandigheden samengehouden zouden worden. ${ }^{\mathbf{2 2}}$ Daarnaast zorgt het EU-Turkije-akkoord ervoor dat minder mensen de oversteek van de Turkse kust maken. ${ }^{\mathbf{2 3}}$ Doordat er echter weinigen teruggestuurd worden naar Turkije, komen de opvangkampen in Griekenland overvol te zitten, wat op zijn beurt tot nieuwe schendingen van de mensenrechten leidt. ${ }^{\mathbf{2 4}}$ Onderstaande tabel geeft een evolutie weer.

FIGUUR 1: Evolutie van aantal NBMV in Europa (selectie)

\begin{tabular}{|l|l|l|l|l|l|l|}
\hline Locatie / Data & $\mathbf{2 0 1 3}$ & $\mathbf{2 0 1 4}$ & $\mathbf{2 0 1 5}$ & $\mathbf{2 0 1 6}$ & $\mathbf{2 0 1 7}$ & $\mathbf{2 0 1 8}$ \\
\hline EU (28 landen) & 12.725 & 23.150 & 985.205 & 63.245 & 31.395 & 19.750 \\
\hline België & 415 & 470 & 2.545 & 1.020 & 735 & 810 \\
\hline Duitsland & 2.485 & 4.400 & 22.255 & 35.935 & 9.085 & 4.085 \\
\hline Frankrijk & 365 & 270 & 320 & 475 & 590 & 740 \\
\hline Griekenland & 325 & 440 & 420 & 2.350 & 6.020 & 10.005 \\
\hline Italië & 805 & 2.505 & 4.070 & 1.705 & 1.180 & 1.225 \\
\hline Nederland & 310 & 960 & 3.855 & 2.640 \\
\hline
\end{tabular}

Bron: Eurostat $\mathbf{2 5}$

Een belangrijke opmerking hierbij is dat deze aantallen volgens UNICEF slechts 'het topje van de ijsberg' zouden zijn, aangezien alleen met geregistreerde NBMVs rekening wordt gehouden. ${ }^{\mathbf{2 6}}$ 


\section{Hoofdstuk II. Onderzoeksvragen, methodologie en structuur}

5. Centrale onderzoeksvraag en sub-onderzoeksvragen - 'In hoeverre zijn de voorstellen van het GEAS in overeenstemming met de mensenrechten van de NBMV en hoe kunnen deze voorstellen volledig in lijn gebracht worden met deze mensenrechten?', is de vraag waarop een antwoord gezocht wordt. Ter ondersteuning van deze centrale onderzoeksvraag worden ook enkele sub-onderzoeksvragen geformuleerd:

- 'Wie is de NBMV en wat is het GEAS?' Dit is een beschrijvende vraag die de lezer een breder kader biedt zodat hij de achtergrond ten volle kan begrijpen. ${ }^{27}$

- 'Hoe ziet het mensenrechtelijk kader van de NBMV eruit?' Ook dit is een beschrijvende vraag; de bedoeling is dat de lezer nu ook de mensenrechten van de NBMV kent.

- 'Voldoen de voorstellen omtrent de regelgeving van het GEAS aan de mensenrechten van de niet-begeleide minderjarige vreemdeling?' Dit is een evaluatieve vraag waarop een beoordeling volgt aan de hand van internationale en Europese criteria in verband met de mensenrechten. ${ }^{\mathbf{2 8}}$

6. Methodologie - In de eerste plaats werd de interpretatieve methode gehanteerd. ${ }^{29}$ De rechtsfiguren werden geanalyseerd aan de hand van verschillende documenten. Belangrijk waren de verdragsteksten en (mensenrechtelijke) rechtsinstrumenten. Daarnaast werd de relevante rechtsleer onderzocht, die af en toe een nieuw licht op de teksten wierp. Ook werd de toetsingsmethode toegepast. De derde sub-vraag betrof immers een evaluatieve vraag; de beantwoording van een evaluatieve vraag kan gebeuren aan de hand van de aftoetsing van een bestaande situatie aan welbepaalde criteria. ${ }^{\mathbf{0}}$ Zo kon bijvoorbeeld getoetst worden aan 'het belang van het kind'.

7. Wetsvoorstellen - Concreet is ingegaan op meer primaire bronnen, zoals de verslagen van het Parlement, de voorstellen van de Commissie en nota's van de Raad. Ook voorbereidende werken, rapporten en huidige wetgeving werden daarbij nagegaan. Hierbij werd een eerste grens aangebracht; namelijk op de te onderzoeken documenten binnen het GEAS-contentieux. Het onderzoek richtte zich voornamelijk op de voorstellen ten aanzien van de Opvangrichtlijn, het Dublinsysteem en ook deels op de Procedureverordening. De voorstellen rond Eurodac, het Asielagentschap en de Kwalificatieverordening ${ }^{\mathbf{3 1}}$ werden eerder op de achtergrond gehouden. Omwille van het feit dat zij ten aanzien van de NBMV weinig problematisch of veelal eerder organisatorisch en technisch van aard lijken te zijn, werden zij slechts subsidiair behandeld. ${ }^{\mathbf{2}}$

8. Onderzochte rechten - Aangezien de term 'rechten van de NBMV' ruim ingevuld kan worden, vereiste het onderzoek ook hier een grens. De focus ligt voornamelijk op de artikelen 3 en 5 EVRM en het belang van het kind. Dit omdat uit de reeds uitgevoerde studies rond het GEAS bleek dat de meeste pijnpunten in verband met de mensenrechten zich rond deze rechten bevinden. ${ }^{33}$ Het zijn vooral ook deze rechten die terug te vinden zijn in de rechtspraak van het Europees Hof voor de Rechten van de Mens (EHRM) met betrekking tot de NBMV. ${ }^{34}$

9. Geen nationaal recht - Een belangrijke opmerking, ten slotte, is dat er niet is ingegaan op het specifiek nationaal recht. Hier ligt dan ook een derde grens. Er werd alleen een stand van zaken gegeven met betrekking tot het internationale en Europese speelveld. Indien nodig werden referenties en voorbeelden met betrekking tot nationale rechtspraak en wetgeving gegeven, al diende dit louter ter verduidelijking en illustratie.

10. Structuur - Het eerste deel nodigt de lezer uit om de begrippen 'NBMV' en 'GEAS' zo grondig mogelijk te vatten. Vervolgens wordt ingegaan op de mensenrechten van de NBMV, waarna deze mensenrechten en het GEAS verder onder de loep genomen worden. In het besluit worden ten slotte de krachtlijnen uit elk onderdeel naar boven gehaald.

\section{DEEL I: De NBMV en het GEAS}

\section{Hoofdstuk I. Het GEAS}

'If the current refugee crisis has shown one thing, it is that the status quo of our Common European Asylum System is not an option. The time has come for a reformed and more equitable system, based on common rules and a fairer sharing of responsibility. ${ }^{35}$ - Dimitris Avramopoulos

11. Een nieuwe update voor het GEAS - Deze woorden van Dimitris Avramopoulos, oud-EU-Commissaris voor Migratie, geven duidelijk aan dat het asielstelsel van de EU aan een update toe is. Dit is nochtans niet de eerste update; het gemeenschappelijk asielstelsel kent namelijk een hobbelige geschiedenis die teruggaat tot 1999.

12. Historische ontwikkeling - In dat jaar ontstond immers de idee tot het inrichten van het Gemeenschappelijk Europees Asielstelsel (GEAS, Common European Asylum System, CEAS). ${ }^{\mathbf{6}}$ De Europese Raad kwam in Tampere overeen om een asielsysteem in te richten door een wetgevend kader te creëren dat alle aspecten van het asielbeleid bestrijkt. ${ }^{37} \mathrm{Zo}$ waren er bijvoorbeeld richtlijnen rond asielprocedures, de opvang van asielzoekers en tijdelijke bescherming, die op een meer gedetailleerde wijze de contouren van het asielbeleid van de individuele lidstaten moesten vastleggen. ${ }^{\mathbf{3}}$ Doorheen de jaren, en vooral in 2015 en 2016, kreeg de EU echter te kampen met onvoorziene grote aantallen asielzoekers. ${ }^{39}$

Critici duiden deze vluchtelingen-'crisis' vaak als een crisis van de EU zelf.40 Ze zou te wijten zijn aan structurele zwakten van het EU-asielbeleid, zoals een te grote nadruk op dwang, irreële verwachtingen rond grensbewaking en een chaotische interne organisatie. ${ }^{\mathbf{4 1}}$ Het asielstelsel werd daarom gedurende de afgelopen twintig jaar vaak aan aanpassingen onderworpen..$^{\mathbf{2}}$ Uiteindelijk kwam de Europese Commissie in 2016 tot enkele voorstellen voor een nieuwe hervorming van het GEAS. De hervorming sleept reeds lange tijd aan en legde af en toe enkele grondslagen van de EU, zoals de Schengenzone, het vuur aan de schenen. 43

13. Hervormingspakketten - In het algemeen kunnen de voorstellen tot hervorming ondergebracht worden in drie categorieën. ${ }^{44}$ Deze werden in de inleiding reeds kort uiteengezet. Met name het tekort aan harmonisatie binnen de EU, de gebrekkige implementatie van de Unieregelgeving en de verdeling van de asielzoekers over de lidstaten, werden als problematisch bestempeld. ${ }^{45}$ Concreet heeft de Europese Commissie twee pakketten aan voorstellen gelanceerd om deze problemen te verhelpen. ${ }^{\mathbf{4}}$ Het eerste pakket werd voorgesteld op 4 mei 2016 en bevat drie initiatieven:

- Het voorstel voor een verordening ter hervorming van het Dublin-verdeelsysteem. ${ }^{47}$ Het Dublin-verdeelsysteem duidt de lidstaat aan die verantwoordelijk is voor het behandelen van een asielaanvraag (hierover meer in Deel III). ${ }^{\mathbf{8}}$

- Het voorstel voor een verordening ter amendering van Eurodac.49 Eurodac is een informatiesysteem dat digitale 
vingerafdrukken van asielzoekers verzamelt om de toepassing van het Dublin-verdeelsysteem te vergemakkelijken. ${ }^{\mathbf{o}}$

- Het voorstel voor een verordening ter creatie van een Asielagentschap dat het European Asylum Support Office (EASO) moet vervangen.$^{\mathbf{5 1}^{\mathbf{1}}}$ Het EASO stimuleert de samenwerking tussen de lidstaten op vlak van nationaal beleid in verband met asiel..$^{2}$

Het tweede pakket werd in datzelfde jaar op 13 juli aangenomen en bevat:

- Het voorstel voor een nieuwe verordening die de Procedurerichtlijn moet vervangen.53 Deze richtlijn legt enkele procedurele waarborgen vast die gelden tijdens de asielprocedure. ${ }^{\mathbf{4}}$

- Het voorstel voor een nieuwe verordening die de Kwalificatierichtlijn moet vervangen. ${ }^{55}$ De Kwalificatierichtlijn bepaalt wie voor asiel in aanmerking komt. ${ }^{\mathbf{6}}$

- Het voorstel voor aanpassingen aan de Opvangrichtlijn. ${ }^{57}$ Deze bevat de minimumnormen voor opvangvoorzieningen voor asielzoekers en statushouders. ${ }^{\mathbf{8}}$

14. Wachten op een standpunt van de Raad: wachten op Godot? - De hervorming van het GEAS valt onder de gewone wetgevingsprocedure.59 Deze procedure nam een aanvang in 2016, toen de Commissie haar voorstellen bekendmaakte. Vervolgens heeft het Parlement hierop in 2017 gereageerd aan de hand van een reeks amendementen. ${ }^{\mathbf{6 o}}$ Sindsdien is het aan de Raad om een standpunt in te nemen, maar dat proces is tot op heden niet volledig afgerond. ${ }^{\mathbf{6 1}}$ Het vorige mandaat van de Commissie en het Parlement is momenteel echter afgelopen. De onderhandelingen over de asielpakketten zijn daarom de facto verschoven naar het volgende mandaat. ${ }^{\mathbf{6 2}}$ De vraag rest vervolgens waar de voorstellen in de toekomst bijgeschaafd kunnen worden, ook ten aanzien van de NBMV.

\section{Hoofdstuk II. De NBMV}

15. Verschillende definities - Het is bovendien niet eenvoudig om één algemene omschrijving te geven van de NBMV. Er bestaan doorheen de internationale verdragen en wetteksten immers verschillende definities van dit begrip. ${ }^{\mathbf{6 3}}$ Daarnaast stelt nationale wetgeving vaak haar eigen criteria voorop. ${ }^{\mathbf{6 4}}$ Bovendien is de groep NBMV zelf ook nog eens zeer heterogeen; ze omvat jongeren van een verschillende afkomst, leeftijd, gezondheid, enzovoort. ${ }^{65}$

16. Oudste definities - In 1996 poneert de VN Hoge Commissaris voor de Vluchtelingen (UNHCR) een van de oudste definities voor de NBMV. ${ }^{66}$ In de Guideline Working with Unaccompanied Children, A Community Based Approach wordt over de NBMV het volgende genoteerd: 'Unaccompanied Children are those separated from both parents and are not being cared for by an adult who, by law or custom, is responsible to do so.' ${ }^{\mathbf{6} 7}$ Vervolgens stelt de Raad van de Europese Unie in haar Resolutie ${ }^{\mathbf{6 8}}$ van 26 juni 1997 een gelijkaardige definitie voor. ${ }^{69}$ Het gaat met name om:

\footnotetext{
'(...) onderdanen van derde landen jonger dan 18 jaar die zonder begeleiding van een volwassene die krachtens de wet of het gewoonterecht voor hen verantwoordelijk is, op het grondgebied van een lidstaat aankomen voor de duur dat zij niet daadwerkelijk onder de hoede staan van zo'n volwassene. ${ }^{70}$
}

17. Latere EU-regulering - Ten slotte zijn er, sinds de oprichting van het GEAS, ook in de verordeningen en richtlijnen binnen het EU-contentieux nog verschillende definities terug te vinden. ${ }^{\mathbf{1}}$ Zo staat in artikel 2 van het voorstel voor de Dublin IVverordening het volgende:

'[De niet-begeleide minderjarige is] een minderjarige die zonder begeleiding van een krachtens de wet of volgens de praktijk van de betrokken lidstaat voor hem verantwoordelijke volwassene op het grondgebied van een lidstaat aankomt, zolang hij niet daadwerkelijk onder de hoede van een dergelijke volwassene staat; onder dit begrip valt ook een minderjarige die zonder begeleiding wordt achtergelaten nadat hij op het grondgebied van een lidstaat is aangekomen. ${ }^{72}$

18. Constitutieve elementen - Hoewel ze niet volledig gelijk zijn, kunnen uit al deze definities enkele gemeenschappelijke elementen gedestilleerd worden. Met name verdienen de begrippen 'minderjarig', 'niet begeleid' en 'vreemdeling' een uitgebreider onderzoek.

19. Leeftijd - In de eerste plaats is de NBMV minderjarig. ${ }^{73}$ Dit houdt volgens de nationale wetgeving van de verschillende (Europese) landen in dat hij de leeftijd van achttien jaar nog niet bereikt heeft. ${ }^{74}$ Het Kinderrechtenverdrag (1989) stelt verder dat het bij minderjarigheid gaat om iedere persoon die jonger is dan achttien jaar, voor zover hij volgens het recht dat op hem van toepassing is, niet eerder de meerderjarigheid zou bereiken. ${ }^{75}$ Een adolescent kan bijvoorbeeld volgens zijn nationale wetgeving meerderjarig zijn, terwijl hij volgens het land van verblijf nog minderjarig is. Zo ligt de leeftijd voor meerderjarigheid in Libië en Malawi op zestien jaar. ${ }^{\mathbf{6}}$ Een zestienjarige Libische persoon zou dus meerderjarig kunnen zijn volgens zijn nationale wetgeving, terwijl hij volgens de Belgische wetgeving nog minderjarig is. ${ }^{77}$

Om dit onderscheid op te vangen, sluiten bijna alle nationale vreemdelingenwetten in Europa de toepassing van de nationale wet van de vreemdeling uit. ${ }^{\mathbf{8}}$ Ook stelt de Resolutie van 1997 uitdrukkelijk dat het gaat om personen jonger dan achttien jaar. ${ }^{79}$ Dit is tevens opgenomen in de voorstellen rond de hervorming van het GEAS. ${ }^{80}$ De adolescent zal in de EU dus toch als een minderjarige worden beschouwd, ook al is hij volgens zijn nationale wetgeving meerderjarig.

20. Moeilijkheden - Vaak is het echter problematisch om de leeftijd van de vreemdelingen juist in te schatten. ${ }^{\mathbf{8 1}} \mathrm{Ze} \mathrm{beschikken}$ immers zelden over correcte, al dan niet authentieke, identiteitsdocumenten. ${ }^{\mathbf{8 2}}$ Verschillende nationale wetten bepalen meer concreet hoe de leeftijdsschatting moet gebeuren. ${ }^{\mathbf{8 3}}$ Bijgevolg kunnen de methoden doorheen de lidstaten al eens verschillen. ${ }^{\mathbf{8 4}}$ Zo bepaalt de Belgische Programmawet van 24 december 2002 dat in geval van twijfel naar de laagst geschatte leeftijd gekeken moet worden. 85

Nochtans is de leeftijdsbepaling een heikel punt; met de schatting moet voorzichtig worden omgesprongen. ${ }^{\mathbf{8 6}}$ Zo niet loopt de NBMV immers het risico als volwassene beschouwd te worden en zijn rechten als kind te verliezen. ${ }^{\mathbf{8}} \mathbf{7}$ De medischwetenschappelijke wereld lijkt zich hiervan bewust en tracht verschillende technieken te ontwikkelen om de leeftijd van een kind zo precies mogelijk in te schatten. ${ }^{\mathbf{8 8}}$ Medische tests worden echter bekritiseerd omwille van de privacy van de NBMV, ${ }^{\mathbf{8 9}}$ maar ook omwille van de gevolgen op de gezondheid van het kind ${ }^{\mathbf{9 0}}$ en de mogelijke onnauwkeurigheden.91 Bovendien levert deze 
wetenschappelijke benadering geen oplossing voor het gegeven dat de methoden doorheen de lidstaten verschillen. Om dat probleem op te lossen, zou er eerder een ingreep van de EU-regelgevers nodig zijn. ${ }^{\mathbf{2}}$

21. Niet-begeleid: pragmatische tegenover juridische strekking - Het tweede element houdt in dat de betrokkene niet begeleid is bij zijn aankomst in de EU of nadien. ${ }^{\mathbf{9 3}}$ Ook rond dit element bestaat er discussie. ${ }^{\mathbf{9 4}}$ Langs de ene kant stelt een pragmatische strekking dat de minderjarige pas niet-begeleid is wanneer hij door geen enkele volwassene vergezeld wordt.95 Zo is het mogelijk dat de minderjarige zonder ouders, maar met een oudere broer of zus aankomt en bijgevolg als begeleid beschouwd wordt. De tweede, meer juridische, strekking gaat ervan uit dat de minderjarige niet begeleid is wanneer hij niet vergezeld is van zijn wettelijke vertegenwoordiger. ${ }^{\mathbf{6}}$ Dit is tevens de strekking die de EU-regelgevers volgen, wat veiliger is. ${ }^{\mathbf{9 7}}$ De pragmatische strekking houdt namelijk het risico in dat minderjarigen die vergezeld zijn van een volwassene die zich voordoet als begeleider, maar een andere opzet, zoals mensensmokkel, heeft, toch als begeleid worden beschouwd.98

22. Europees burgerschap? - Ten slotte gaat het om een vreemdeling, wat in dit kader veelal inhoudt dat de betrokkene geen onderdaan is van een land dat tot de Europese Economische Ruimte behoort. ${ }^{99}$ Indien het individu toch een Europees burger zou zijn, dan kan hij door verschillende lidstaten als Europese NBMV erkend worden, mits hij aan enkele vereisten voldoet. Deze worden bepaald in de nationale wetgeving van de lidstaten. ${ }^{\mathbf{1 0 0}}$

23. Met kwetsbaarheid als gevolg - Hoewel 'kwetsbaar' niet letterlijk voorkomt in de definities van de NBMV, onderlijnen verschillende auteurs dat de NBMV door de combinatie van deze elementen zeer kwetsbaar is. Dit zien critici dan ook als een vierde eigenschap van de NBMV. ${ }^{\mathbf{1 0 1}}$ De minderjarigen lopen door de kwetsbaarheid een verhoogd risico op een inbreuk op hun rechten. ${ }^{\mathbf{1 0 2}}$ Veelal zijn ze 'onzichtbaar' voor de overheden. ${ }^{\mathbf{1 0 3}}$ Zo berichtte de Dienst Voogdij van de Federale Overheidsdienst Justitie dat er in België in 2018 opnieuw een heel aantal NBMVs onder de radar doken. ${ }^{\mathbf{1 0 4}}$

\section{Hoofdstuk III. Deelbesluit}

24. Schijnbaar eenvoudige kenmerken - Problemen in verband met implementatie, harmonisatie en een correcte verdeelsleutel zetten de EU-regelgevers ertoe aan hun GEAS aan een herevaluatie te onderwerpen. Terwijl de debatten rond de hervorming worden voortgezet, komen nog elke dag een groot aantal asielzoekers aan in Europa. Onder hen bevindt zich de groep NBMV, jongeren die om verschillende redenen zonder ouders Europa binnenkomen.

Deze groep is heterogeen en dekt jongeren van verschillende leeftijden en afkomst. Gemeenschappelijk hebben al deze minderjarigen wel dat ze schijnbaar eenvoudigweg minderjarig, vreemdeling en niet-begeleid zijn. 'Schijnbaar', want deze eigenschappen zijn niet gemakkelijk te bepalen en worden veelal verschillend ingevuld, wat tot een gebrek aan aangepaste bescherming kan leiden. Zeker het bepalen van de leeftijd van de vreemdeling blijft een moeilijke kwestie. Een tussenkomst van de EU-regelgevers lijkt hier wenselijk; zo kunnen de wetenschappelijke technieken en methoden doorheen de lidstaten meer op elkaar afgestemd worden. Het volgende deel gaat na welke mensenrechten van de NBMV er bij dergelijke aanpassingen kunnen meespelen.

\section{Deel II. De NBMV en de mensenrechten}

\section{Hoofdstuk I. Algemeen Mensenrechtelijk kader}

\section{Afdeling I. Internationale beschermingsnormen}

25. UVRM - Voor wat betreft de mensenrechten van de NBMV bestaat er in de eerste plaats het overkoepelende artikel 14 van de Universele Verklaring van de Rechten van de Mens (UVRM) dat stipuleert dat 'eenieder het recht heeft om in andere landen asiel te zoeken en rechten te genieten tegen vervolging'. ${ }^{\mathbf{1 0 5}}$ Ook minderjarigen kunnen zich op de Verklaring beroepen. ${ }^{\mathbf{1 0 6}}$ 26. Vluchtelingenverdrag en Protocol - Het oudste internationale verdrag dat zijn toepassing vindt op de NBMV als vluchteling is het Internationaal Verdrag betreffende de Status van Vluchtelingen (Vluchtelingenverdrag, Verdrag van Genève) ${ }^{{ }^{107}}$ Het Verdrag heeft een algemeen toepassingsgebied en voert criteria in voor wie als vluchteling kan worden erkend. ${ }^{\mathbf{1 0 8}}$ In het Verdrag zelf wordt niet specifiek dieper ingegaan op de NBMV. Ook worden aan de minderjarige vluchtelingen in dit verdrag geen eigen, specifieke rechten toegekend. ${ }^{\mathbf{1 0 9}}$

Als niet-statelijke actor is de EU zelf geen partij bij dit verdrag. Elke EU-lidstaat is dat echter wel.110 Ook wordt er in artikel 18 van het Handvest van de Grondrechten van de Europese Unie naar dit Verdrag en zijn Protocol verwezen. ${ }^{\mathbf{1 1 1}}$ Daarenboven is het zo dat, onder artikel 78.1 van het Verdrag betreffende de werking van de Europese Unie (VWEU), de EU zich ertoe verbindt om de beginselen uit dit Verdrag te respecteren bij de ontwikkeling van het GEAS. ${ }^{\mathbf{1 1 2}}$ Bovendien gaf de Europese Raad in 1999 in Tampere aan een GEAS te willen creëren dat 'stoelt op de volledige en niet-restrictieve toepassing van het Verdrag van Genève'.113 Ten slotte heeft ook het Hof van Justitie van de EU (HvJ) bevestigd dat de EU-instrumenten zo geïnterpreteerd moeten worden dat ze het Vluchtelingenverdrag respecteren. ${ }^{114}$

27. Kinderrechtenverdrag - Vervolgens kwam er het Verdrag inzake de Rechten van het Kind. ${ }^{\mathbf{1 1 5}}$ Dit verdrag vindt in zijn geheel toepassing ${ }^{\mathbf{1 1 6}}$ op de NBMV en bevat een specifiek artikel dat gericht is op de minderjarige vreemdeling.17 Artikel 22 bepaalt namelijk dat staten die partij zijn bij het verdrag 'de passende maatregelen moeten nemen om te waarborgen dat dit kind passende bescherming en humanitaire bijstand krijgt'.118 Belangrijk is hier ook artikel 2;19 het gevolg van dit artikel is dat de NBMV de bepalingen van het Kinderrechtenverdrag kan inroepen, ongeacht of hij reeds een verblijfsvergunning heeft gekregen. ${ }^{\mathbf{1 2 0}}$ Essentieel in dit verdrag is de bepaling rond het belang van het kind; daar gaat hoofdstuk II verder op in. Opnieuw is de EU als zodanig geen partij bij dit verdrag, maar alle EU lidstaten zijn dat wel. ${ }^{\mathbf{1 2 1}}$

28. Het Migratiepact - Op 13 juli 2018 nam de VN het finale ontwerp van het 'Mondiaal Pact voor Veilige, Ordelijke en Reguliere Migratie' oftewel het Migratiepact aan. ${ }^{\mathbf{1 2 2}}$ Dit Pact is niet juridisch bindend en de principes moeten niet worden omgezet in wetgeving. ${ }^{123}$ In december 2018 heeft de Algemene Vergadering van de VN het Pact onderschreven met 152 stemmen voor. ${ }^{\mathbf{1 2 4}}$ Het Pact werd niet door alle EU-lidstaten onderschreven en sommige EU-lidstaten onthielden zich. ${ }^{\mathbf{1 2 5}}$ Samen met de niet-bindende aard van het Pact zorgt dit ervoor dat de draagkracht van het Pact in de EU enigszins beperkt is. In het Pact richten doelstellingen 7, 8 en 12 zich op de NBMV. Zo bepaalt doelstelling 7 dat kwetsbaarheden in migratie moeten aangepakt en verminderd worden door een aangepast beleid en door het stimuleren van samenwerking tussen landen. Er moet de NBMV bijvoorbeeld aangepaste ondersteuning geboden worden gedurende de gehele migratieprocedure. ${ }^{\mathbf{1 2 6}}$ 29. Evaluatie: geen specifieke focus op de NBMV - Uit de bovenstaande uiteenzetting van internationale bronnen blijkt dat er niet bijzonder veel specifieke bepalingen en geen verdragen rond de NBMV bestaan. Andere groepen die door regelgevers als kwetsbaar beschouwd worden, beschikken wel over een eigen verdrag. Zo zijn er bijvoorbeeld het Verdrag inzake de Uitbanning van Rassendiscriminatie en het Verdrag inzake de Rechten van de Personen met een Handicap. De NBMV moet zich voornamelijk beroepen op het Kinderrechtenverdrag en het Vluchtelingenverdrag, maar deze instrumenten verwijzen nauwelijks naar minderjarige vreemdelingen, of naar de NBMV, als specifieke groep kwetsbare personen. Critici stellen dat bijvoorbeeld het Kinderrechtenverdrag daarom niet altijd kan voldoen aan de noden van deze kinderen; zo formuleren Farrugia en Touzenis: 
'It would have been preferable if a specific article had addressed this group of [migrant] children, obviously underlining the need to apply the entire Convention [on the rights of the child] to migrant children, as an especially vulnerable group.' ${ }^{127}$

Wel trachtte het VN-Kinderrechtencomité reeds meer duidelijkheid te scheppen aan de hand van General Comment nr. 6, dat de omgang met NBMVs uiteenzet. ${ }^{\mathbf{2 8}}$ Hoewel General Comments zeker een gezaghebbende interpretatie bieden, hebben ze strikt gezien geen bindende kracht. ${ }^{\mathbf{1 2 9}}$ Gezien de hoedanigheid en kwetsbaarheid van de NBMV, kan men zich dan ook de vraag stellen of de bovenstaande verdragen voldoende bescherming bieden.

30. Rechtstreekse werking - Bovendien is het voor de NBMV niet altijd eenvoudig om zich effectief te beroepen op deze internationale normen. Er bestaat namelijk van oudsher een verschil tussen dualistische en monistische systemen. ${ }^{\mathbf{1 3 0}}$ Wanneer een individu in een monistisch systeem een recht uit een verdrag wil inroepen, kan hij zich rechtstreeks op het verdrag kan beroepen, en niet noodzakelijk op een nationale wet zoals in het dualistisch systeem het geval is. In een monistisch systeem is het wel zo dat de verdragsbepaling slechts inroepbaar is wanneer ze rechtstreekse werking heeft. ${ }^{\mathbf{1 3 1}}$

Het is concreet aan de nationale rechter om te bepalen of een verdragsbepaling uit het internationaal recht al dan geen rechtstreekse werking heeft. ${ }^{\mathbf{1 3 2}}$ Voor wat betreft bijvoorbeeld het Kinderrechtenverdrag is de praktijk bij de Europese rechters zeer uiteenlopend. ${ }^{\mathbf{1 3 3}}$ In België bestaat er bij de Raad van State en het Hof van Cassatie een zekere tendens om aan verschillende bepalingen uit het Kinderrechtenverdrag géén rechtstreekse werking toe te schrijven. ${ }^{\mathbf{1 3 4}}$ In Nederland heerst er enigszins onduidelijkheid over de rechtstreekse werking; sommige rechters kennen de rechtstreekse werking toe, andere niet. ${ }^{\mathbf{1 3 5}}$ In Frankrijk, ten slotte, lijkt de rechtspraak dan weer te bevestigen dat de bepalingen uit het Kinderrechtenverdrag wel rechtstreekse werking hebben. ${ }^{\mathbf{1 3 6}}$ Ook zou het Migratiepact zou als dusdanig geen rechtstreeks werkend karakter hebben. ${ }^{\mathbf{1 3 7}}$

\section{Afdeling II. Europese beschermingsnormen}

31. Weinig coherentie - Op Europees niveau wordt aan de NBMV een weinig coherente bescherming geboden. Er bestaat namelijk geen specifieke wettekst die zich richt op deze groep jongeren, de toepasselijke beschermingsnormen zijn versnipperd terug te vinden in diverse verdrags- en wetteksten. Carlier en Carole wijten dit aan het specifieke karakter van de NBMV en formuleren het als volgt: 'Leur spécificité, liée à leur vulnérabilité, a pour conséquence que diverses dispositions leur sont consacrées dans de nombreux textes de droit dérivé'. ${ }^{138}$

32. Het Handvest - Naast een bundel aan soft law, ${ }^{\mathbf{1 3 9}}$ is er in de eerste plaats het Handvest van de Grondrechten van de Europese Unie (2000). ${ }^{\mathbf{1 4 0}}$ Het Handvest is slechts van toepassing wanneer de lidstaten EU-regelgeving ten uitvoer brengen en is dus van toepassing op de implementatie van het GEAS. ${ }^{\mathbf{1 4 1}}$ Daarnaast kunnen de bepalingen uit het Handvest worden ingeroepen door zowel EU-burgers als niet-EU-burgers. ${ }^{\mathbf{1 4 2}}$ In dit Handvest richt artikel 18 zich op het asielrecht. ${ }^{\mathbf{1 4 3}}$ Hierin wordt verwezen naar het Vluchtelingenverdrag en het bijhorende Protocol. ${ }^{\mathbf{1 4 4}}$ Ook bevat het Handvest enkele bepalingen in verband met de rechten van het kind (zo bijvoorbeeld rond onderwijs, arbeid, enz.).

33. Het EVRM - Daarnaast is er natuurlijk ook het Europees Verdrag voor de Rechten van de Mens (EVRM). Dit verdrag kent een ruimer toepassingsgebied en is van toepassing op de leden van de Raad van Europa. ${ }^{\mathbf{1 4 5}}$ Het is echter niet van toepassing op de EU en de EU-instellingen zelf. ${ }^{\mathbf{1 4 6}}$ Een belangrijke nuance hierbij is dat het EHRM doorheen de jaren bepaalde technieken ontwikkelde om via de EU-lidstaten toch aan EU-regelgeving te toetsen. ${ }^{\mathbf{1 4 7}}$ In het EVRM zijn geen specifieke bepalingen terug te vinden rond de vreemdeling, laat staan de niet-begeleide vreemdeling. ${ }^{\mathbf{1 4 8}}$ Het EVRM is een meer algemeen

mensenrechtenverdrag en het biedt bijgevolg onvoldoende criteria om rekening te houden met de specifieke hoedanigheid van de NBMV. ${ }^{149}$ Daarenboven is ook voor het EVRM de rechtstreekse werking niet vanzelfsprekend; zo kent het Italiaanse Corte Costituzionale aan de bepalingen uit het EVRM geen rechtstreekse werking toe, terwijl het Servische Hof van Cassatie dat wel deed. ${ }^{150}$

34. De GEAS-puzzel - Vervolgens bestaat er een bundel secundaire regelgeving die betrekking heeft op de positie van de NBMV binnen het GEAS. ${ }^{151}$ De voorstellen voor het nieuwe GEAS, alsook de huidige Procedurerichtlijn, de Kwalificatierichtlijn en de Opvangrichtlijn bevatten bijvoorbeeld bepalingen die het statuut van de NBMV regelen. De NBMV moet eerst en vooral de verschillende richtlijnen en verordeningen uit het GEAS kennen en daarna uit deze GEAS-instrumenten de juiste artikelen naar boven halen. Hierbij valt nog op te merken dat zowel de regels van het GEAS als van het EU-verdragsrecht van toepassing zijn op alle EU-lidstaten, en dat ook hier de principes in verband met rechtstreekse werking van toepassing zijn. ${ }^{\mathbf{1 5 2}}$ Belangrijk is dat er qua EU-regelgeving nog een onderscheid gemaakt moet worden tussen verordeningen en richtlijnen. ${ }^{\mathbf{5} 3}$ Voor de NBMV bestaat er dus een verschil naargelang hij zijn rechten uit bijvoorbeeld de Dublinverordening, dan wel de Opvangrichtlijn rechtstreeks wil inroepen. Het volgende hoofdstuk gaat dieper in op enkele specifieke mensen- en kinderrechten.

\section{Hoofdstuk II. Specifieke rechten}

\section{Afdeling l. Het verbod op foltering}

35. Het verbod op foltering - Dit verbod kreeg voor het eerst vorm in 1966, toen het Internationaal Verdrag inzake Burgerrechten en Politieke Rechten (IVBPR) ondertekend werd in New York. In dit verdrag richt artikel 7 zich op het verbod op foltering: niemand mag worden onderworpen aan folteringen, noch aan wrede, onmenselijke of onterende behandeling of bestraffing. Een definitie van het begrip 'foltering' wordt echter pas later gegeven, in het Folterverdrag. ${ }^{154}$ Ook komt het verbod terug in artikel 37 lid a van het Kinderrechtenverdrag.

Daarnaast is het verbod ook terug te vinden in artikel 3 EVRM. Dit artikel stipuleert dat: 'Niemand mag worden onderworpen aan folteringen of aan onmenselijke of vernederende behandelingen of bestraffingen.' De voorziening is absoluut, ze laat geen beperkingen toe en kan niet afgewogen worden tegenover andere factoren. ${ }^{\mathbf{1 5 5}}$ Ten slotte werd het principe verder uitgewerkt in het 'Europees Verdrag ter voorkoming van Foltering en Onmenselijke of Vernederende Behandeling of Bestraffing'. ${ }^{\mathbf{5 6}}$ 36. Non-refoulement in het internationaal recht - Het refoulementverbod bouwt voort op dit verbod. Meer algemeen houdt dit beginsel in dat een vreemdeling niet kan uitgezet of teruggeleid worden naar een land wanneer zijn leven of vrijheid bedreigd zouden worden. ${ }^{157}$ Een eerste vindplaats voor het refoulementverbod is binnen het internationaal recht. In 1951 werd het namelijk opgenomen in artikel 33 van het Vluchtelingenverdrag. ${ }^{\mathbf{1 5}}$ Dit artikel bevat het verbod tot uitzetting of terugleiding en is verder aldus bekend als het refoulementverbod. ${ }^{159}$ De enige uitzondering hierop moet restrictief geïnterpreteerd worden en geldt wanneer de asielzoeker een gevaar oplevert voor de veiligheid of de gemeenschap van het land waar hij zich bevindt. ${ }^{\mathbf{1 6 0}}$ 37. Non-refoulement in Europa: artikel 3 EVRM - Binnen de Europese context is het verbod terug te vinden in artikelen 4 en 19 van het Handvest van de Grondrechten van de Europese Unie. ${ }^{\mathbf{1 6 1}}$ Daarnaast bevat het verbod ook een link met het EVRM. Wanneer een individu wordt overgedragen aan een land waarvan de opvangomstandigheden in strijd zijn met artikel 3 EVRM, wordt uitgegaan van een schending van het refoulementverbod. ${ }^{\mathbf{1 6 2}}$ Gezien het beginsel zowel in het Handvest als in het EVRM op bijna identieke wijze is opgenomen, laat het een controle door twee hoven toe. In de eerste plaats kan het EHRM logischerwijze toetsen aan het EVRM. Daarnaast kan ook het HvJ een controlefunctie uitoefenen doordat het GEAS een toepassing van het EU- 
recht vormt. Hetzelfde geldt voor het volgende recht, het recht op vrijheid en veiligheid.

\section{Afdeling II. Het recht op vrijheid en veiligheid}

38. Europese en internationale verankering - Omgevingen van opsluiting, zoals gevangenissen en detentiecentra, vormen vaak een katalysator voor schendingen van de mensenrechten, waaronder ook de rechten van kinderen. ${ }^{\mathbf{6} 3}$ Vanuit dit besef werden in de jaren 1930 door de VN de Standard Minimum Rules for Prisoners uitgevaardigd. ${ }^{164}$ In 1950 nam Europa als eerste verder initiatief en poneerde via artikel 5 EVRM het fundamentele recht op vrijheid en veiligheid. Bovendien moeten beperkingen op dit fundamentele recht aan bepaalde voorwaarden voldoen. ${ }^{\mathbf{1 6 5}} \mathrm{Om}$ arbitraire detenties te vermijden geeft het artikel niet alleen een lijstje van gevallen waaronder detentie toegelaten is (art. 5 lid 1 onderdeel a-f), maar voorziet het ook in enkele procedurele waarborgen. ${ }^{166}$ Zo bepaalt artikel 5 lid 1 onderdeel d EVRM dat minderjarigen in principe slechts kunnen worden aangehouden 'met het oog op hun opvoeding', of, in geval van rechtmatige detentie, 'met als oogpunt om hem voor een bevoegde instantie te geleiden' ${ }^{167}$ Zo'n halve eeuw later werd het recht op vrijheid en veiligheid tevens vastgelegd in artikel 6 van het Handvest van de Grondrechten van de Europese Unie. ${ }^{\mathbf{1 6 8}}$

Internationaal werd het recht in 1966 verankerd in de artikelen 9 en 10 IVBPR. ${ }^{\mathbf{1 6 9}}$ Dit bindende instrument bepaalt niet enkel dat er een recht op vrijheid en veiligheid moet zijn, maar het stipuleert ook dat elke persoon die reeds van zijn vrijheid beroofd is, met eerbied en respect voor de menselijke waardigheid behandeld moet worden. Dit is vrij uniek, het EVRM maakt van deze laatste bepaling geen gewag. ${ }^{\mathbf{1 7 0}}$

39. Veiligheid en vrijheid van het kind: 3 basisvoorwaarden - Daarnaast bevat ook het Kinderrechtenverdrag een eigen bepaling rond de veiligheid en vrijheid van het kind. Artikel 37 poneert, naast het verbod op foltering (art. 37 lid a), ook drie bijzondere basisvoorwaarden waaraan de detentie van een kind moet voldoen. ${ }^{\mathbf{1 7 1}}$ In de eerste plaats is er artikel 37 lid b dat bepaalt dat geen enkel kind op onwettige of willekeurige wijze van zijn of haar vrijheid kan worden beroofd. ${ }^{\mathbf{1 7 2}}$ Dit houdt in dat de aanhouding of gevangenneming van een kind overeenkomstig een duidelijke, niet-arbitraire, wet moet gebeuren en dat het slechts een uitzonderlijke maatregel kan zijn, voor een zo kort mogelijke periode. ${ }^{\mathbf{1 7 3}}$ Ook verankerde het EHRM dit principe in een aantal zaken tegen Frankrijk: een kind kan enkel in detentie gehouden worden volgens artikel 5 lid 1 onderdeel a-f EVRM wanneer het gaat om een ultimum remedium en er geen minder verstrekkende maatregel ter beschikking is. ${ }^{\mathbf{1 7 4}}$

Vervolgens legt artikel 37 lid c de regels rond de omstandigheden van de detentie vast. Een kind moet met eerbied en menselijkheid behandeld worden, wat inhoudt dat er rekening gehouden wordt met de leeftijd van het kind, dat het kind in principe gescheiden wordt van andere volwassenen en dat het kind in beginsel contact kan onderhouden met familieleden. ${ }^{175}$ Tot slot schrijft artikel 37 lid d voor dat het kind over juridische en andere passende bijstand moet kunnen beschikken. ${ }^{\mathbf{1 7 6}}$ 40. NBMV en detentie - Het EHRM sprak zich reeds meerdere malen uit over artikel 5 en de NBMV. Opvallend is dat het in bijna alle gevallen ging om een schending van het artikel door de Griekse overheid. ${ }^{177}$ Vaak betrof de zaak een onrechtmatige arrestatie of detentie, zoals neergeschreven in artikel 5 lid 1 onderdeel f EVRM. ${ }^{178}$ Zo oordeelt het Hof in de zaak Mohamad bijvoorbeeld:

'Compte tenu du fait que le requérant n'a pas été placé dans une structure d'accueil adaptée aux mineurs, conformément à la législation applicable, (...) la Cour conclut que la détention du requérant n'était pas « régulière » au sens de l'article $5 \S 1 \mathrm{f})$ de la Convention et qu'il y a eu violation de cette disposition. ${ }^{179}$

\section{Afdeling III. Het belang van het kind}

41. Principe - Hierboven werd reeds aangehaald dat een van de essentiële bepalingen uit het Kinderrechtenverdrag het principe van het belang van het kind (art. 3 Kinderrechtenverdrag) is. ${ }^{\mathbf{1 8 0}}$ In essentie houdt deze paraplu-bepaling in dat bij alle maatregelen betreffende kinderen, het belang van het kind een prioritaire overweging is. ${ }^{\mathbf{8 1}}$ Dit betekent dat wanneer een kind betrokken is bij een asielprocedure, bij zowel de beslissingen in verband met toegang tot het land als bij de beslissingen in verband met een weigering, voorrang gegeven moet worden aan het belang van het kind. ${ }^{\mathbf{1 8 2}}$

42. Kritiek en discussie - Het belang van het kind wordt in het Kinderrechtenverdrag nauwelijks gedefinieerd. Het Verdrag geeft enkel aan wanneer en hoe het beginsel moet worden toegepast. ${ }^{\mathbf{1 8}}$ Dit maakt het beginsel tot een complex begrip, dat in de praktijk niet altijd eenvoudig kan worden toegepast. ${ }^{\mathbf{1 8 4}}$ Dit gegeven gaf mee de aanzet tot General Comment nummer 14 van het VN-Kinderrechtencomité (2013). ${ }^{\mathbf{1 8 5}}$ Zo beschrijft de Comment dat de vage definiëring het begrip net ook tot een dynamisch concept maakt, waarvan de inhoud bepaald moet worden aan de hand van concrete omstandigheden. ${ }^{\mathbf{1 8 6}}$ Het begrip is hierdoor zeer flexibel en kinderen kunnen hun visie laten bijdragen bij het bepalen van hun belang. ${ }^{187}$ Zeker in het kader van de NBMV is dit een troef, gezien de heterogeniteit van de groep NBMVs. ${ }^{\mathbf{1 8 8}}$

43. Toepassing op de NBMV - Aangezien het beginsel een open norm is, werden in het verleden reeds enkele voorstellen gedaan voor toetsingscriteria, die de toepassing van het beginsel zouden moeten vergemakkelijken. ${ }^{\mathbf{1 8 9}}$ Zo stelden Heiner en Bartels daartoe in 1989 'twaalf ijkpunten' voor. Deze werden door Kalverboer en Zijlstra verder geactualiseerd en geconcretiseerd tot 'veertien ontwikkelingsvoorwaarden' aan de hand van het Best Interest of Child model (BIC-model). ${ }^{\mathbf{1 9 0}}$ Het BIC-model zou het gemakkelijker maken om het belang van het kind toe te passen op asiel- en migratieprocedures. Bovendien zou het rekening houden met de specifieke kwetsbaarheid van de minderjarige vreemdeling. ${ }^{\mathbf{1 9 1}}$

44. EU-vertaling - Tot slot is het beginsel van het belang van het kind ook terug te vinden in artikel 24 van het Handvest van de Grondrechten van de Europese Unie. ${ }^{\mathbf{1 9 2}}$ Daarnaast bevatten ook enkele EU-richtlijnen en EU-verordeningen verwijzingen naar het begrip. Zo bijvoorbeeld in artikel 22 van het voorstel voor de Opvangrichtlijn en in artikel 21-22 van het voorstel voor de Procedureverordening. ${ }^{193}$ In de huidige regelgeving zijn verwijzingen onder andere terug te vinden in artikel 23 van de Opvangrichtlijn. ${ }^{194}$ Een nuance is dat deze instrumenten slechts zelden een concrete invulling van 'het belang van het kind' geven. Er worden geen verdere regels rond de implementatie van het principe aangereikt en het blijft een vage term. ${ }^{\mathbf{1 9 5}} \mathrm{Dit}$ heeft als gevolg dat de lidstaten zelf bepalen hoe het principe moet worden toegepast en dat er hieromtrent soms onduidelijkheden en verschillen bestaan. Ook hier zou een meer concrete invulling aan de hand van richtsnoeren door de EU-regelgevers nuttig kunnen zijn. Deze kunnen bijvoorbeeld gebaseerd zijn op het BIC-model.

\section{Hoofdstuk III. Deelbesluit}

45. Een mensenrechtelijke puzzel - Wat zijn mensenrechtelijke bescherming betreft, moet de NBMV zich beroepen op een grote puzzel aan verdragen. In het internationaal recht vinden we instrumenten die zich richten op de bescherming van het kind in het algemeen, andere teksten hebben op hun beurt voornamelijk betrekking op het statuut van de vreemdeling-vluchteling. Er zijn echter weinig wetteksten, laat staan een afzonderlijk verdrag, die een specifiek artikel aan de NBMV wijden. Daarnaast is het eigen aan de internationaal rechtsregels dat ze niet altijd eenvoudig in te roepen zijn, gezien het feit dat rechtstreekse werking soms ontbreekt.

46. Het belang van het kind als gids doorheen het GEAS - Op Europees niveau is de puzzel niet minder ingewikkeld. De 
specifieke hoedanigheid van de NBMV zorgt ervoor dat zijn statuut verspreid ligt van de Dublinverordening tot het Handvest. Ook hier moet de NBMV zijn weg doorheen de wetgeving goed weten te vinden. Aangezien het internationaal recht weinig specifiek is en soms rechtstreekse werking ontbeert, zou het aangewezen zijn om minstens deze Europese puzzel te vereenvoudigen en een meer coherent systeem op poten te zetten.

Voor wat betreft het belang van het kind, zouden de EU-regelgevers wat meer duidelijkheid kunnen scheppen door richtsnoeren aan te reiken die aangeven hoe het principe toegepast moet worden binnen de context van asiel en migratie. Desalniettemin is het zo dat wanneer de NBMV zijn weg doorheen de GEAS-jungle even niet meer vindt, dit principe hem altijd als gids kan dienen. Of de Europese regelgevers wel voldoende aandacht schenken aan dit beginsel en aan andere rechten van de NBMV, wordt in het volgende deel nader toegelicht.

\section{Deel III: Evaluatie van het GEAS en de mensenrechten}

47. Een controversieel systeem - Een veel bediscussieerd onderdeel van het GEAS is het Dublinsysteem. In dit hoofdstuk wordt eerst onderzocht wat het Dublinsysteem precies is, waarna vervolgens wordt ingegaan op de pijnpunten van het Dublinsysteem in verband met de mensenrechten van de NBMV.

\section{Afdeling l. Het Dublinsysteem}

48. De hoeksteen van het GEAS - Een van de grondslagen van de EU is de Schengenzone. Binnen deze zone kunnen inwoners, en bijgevolg ook asielzoekers, vrij reizen tussen verschillende landen. Het gevolg is dat het risico bestaat dat geen enkel land de verantwoordelijkheid op zich neemt om een asielaanvraag te onderzoeken en dat de asielzoekers van het ene naar het andere land worden gestuurd. ${ }^{\mathbf{1 9 6}}$

Om dit probleem op te lossen, kwamen enkele Europese landen in 1990 tot een akkoord via het Dublinverdrag (Dublin I). ${ }^{\mathbf{1 9 7}}$ De bedoeling van het Verdrag was om gemeenschappelijke en bindende regels vast te leggen ter bepaling van een 'verantwoordelijke lidstaat', die de asielaanvraag moet verwerken. ${ }^{198}$ In 2003 werd het Verdrag vervangen door een Dublinverordening (Dublin II). ${ }^{199}$ Vervolgens werd in 2013 een nieuwe versie van de verordening goedgekeurd, die vandaag nog steeds geldt (Dublin III). ${ }^{\mathbf{2 0 0}}$ De Commissie lanceerde in 2016 met haar GEAS-pakketten een voorstel voor een nieuwe wijziging, dit voorstel wordt het Dublin IV-voorstel genoemd en is het onderwerp van dit hoofdstuk.

Naast de EU-lidstaten ${ }^{\mathbf{2 0 1}}$ nemen ook Noorwegen, IJsland, Zwitserland en Liechtenstein deel aan het huidige Dublinsysteem. ${ }^{\mathbf{2 0 2}}$ Het systeem werd in het Stockholmprogramma, aangenomen in 2009, nog omschreven als de hoeksteen van het GEAS. ${ }^{\mathbf{2 0 3}}$ Gedurende de laatste jaren hebben verschillende arresten van het HvJ en het EHRM de fundamenten van het systeem echter sterk aangetast. ${ }^{\mathbf{2 0 4}}$

49. Welke lidstaat is verantwoordelijk? - De huidige Dublinverordening (Dublin III) stelt dat de verantwoordelijke lidstaat onder andere die lidstaat is 'waar de asielzoeker op illegale wijze de grens heeft overschreden'. ${ }^{\mathbf{2 0 5}}$ Bijgevolg ligt er een grote druk op landen aan de EU-grenzen, zoals Italië en Griekenland; zij behandelen vaak meer asielverzoeken dan andere lidstaten. ${ }^{\mathbf{2 0 6}} \mathrm{De}$ Commissie zag zich dan ook genoodzaakt om een meer billijke verdeling na te streven en ze stelt voor om de verantwoordelijke lidstaat op een andere manier te bepalen.

Het voorstel doet dit door voor elke lidstaat een 'referentieaantal' vast te stellen. Dit aantal bepaalt concreet hoeveel aanvragen de lidstaat moet behandelen. Het referentieaantal wordt berekend aan de hand van een 'referentiesleutel', die gebaseerd is op de omvang van de bevolking en het totale BBP van de lidstaat. ${ }^{\mathbf{2 0} 7}$ Wanneer de lidstaat $150 \%$ van zijn referentieaantal heeft bereikt, treedt een correctiemechanisme in werking en worden de nieuwe asielzoekers herplaatst naar een andere lidstaat. ${ }^{\mathbf{2 0 8}}$ De lidstaten kunnen afzien van dit mechanisme, maar dan moeten ze wel een solidariteitsbijdrage betalen, die toekomt aan het land dat de aanvraag behandelt. ${ }^{209}$

\section{Afdeling II. Kritiek}

\section{\$1. Dublinoverdrachten en verbod op foltering}

50. Dublinoverdracht en artikel 3 EVRM - Zoals reeds uiteengezet, is de bedoeling van het Dublinsysteem dat er één verantwoordelijke lidstaat wordt aangeduid die de asielaanvraag verwerkt..210 Het is namelijk zo dat het aanduiden van één lidstaat het mogelijk maakt snel te bepalen welke lidstaat verantwoordelijk is en op die manier snel toegang tot de procedure te verlenen. ${ }^{\mathbf{2 1 1}}$ Ook zou dit secundaire bewegingen ontmoedigen. ${ }^{\mathbf{2 1 2}}$ Het is dus mogelijk dat een asielzoeker zich in een lidstaat bevindt die niet de verantwoordelijke lidstaat is en dat hij bijgevolg naar dat land moet worden overgebracht. ${ }^{\mathbf{2 1 3}}$ Deze 'Dublinoverdracht' is nochtans niet altijd zo vanzelfsprekend, want rekening houdend met het non-refoulementbeginsel, mag zo'n overdracht zich niet voordoen wanneer de opvangomstandigheden in de verantwoordelijke lidstaat in strijd zijn met artikel 3 EVRM.

Belangrijk in dat verband is dat het Dublin IV-voorstel, net zoals de huidige Dublin III-verordening, een bepaling bevat die stelt: 'de lidstaten, die alle het beginsel van non-refoulement eerbiedigen, worden in dit verband beschouwd als veilige landen voor onderdanen voor derde landen'. ${ }^{\mathbf{1 1 4}}$ Het feit dat alle lidstaten partij zijn bij het Vluchtelingenverdrag en het EVRM en dat ze als EU-leden verplicht zijn fundamentele rechten te beschermen, zorgt ervoor dat ze als 'veilig' worden beschouwd. ${ }^{\mathbf{2 1 5}}$ Nochtans is deze bepaling niet gespaard van kritiek; ze bepaalt niet hoe absoluut de regel precies is en of er bepaalde omstandigheden zijn waarin de regel aan de kant geschoven kan worden. ${ }^{\mathbf{2 1 6}}$

51. HvJ en EHRM in actie - Bovendien oordeelden het EHRM en het HvJ beide dat een Dublinoverdracht wél in strijd kan zijn met het refoulementverbod. ${ }^{\mathbf{2 1}}$ In het kader van de NBMV stelde het EHRM dat de opvangomstandigheden in bijvoorbeeld Griekenland, Italië, Malta en België van die aard waren dat ze een schending van artikel 3 EVRM inhielden. ${ }^{\mathbf{2 1 8}}$ In 2011 bepaalde het EHRM in de baanbrekende zaak M.S.S. t. Griekenland dat Dublinoverdrachten niet noodzakelijk altijd kunnen onder het EVRM. ${ }^{219}$ Niet veel later bevestigde het HvJ dit principe met het N.S.-arrest door te bepalen dat lidstaten in feite enkel asielzoekers kunnen overdragen indien:

'(...) ze niet onkundig zijn van het feit dat de fundamentele tekortkomingen van de asielprocedure en de opvangvoorzieningen voor asielzoekers in deze lidstaat ernstige, op feiten berustende gronden vormen om aan te nemen dat de asielzoeker een reëel risico zal lopen op onmenselijke of vernederende behandelingen in de zin van artikel 4 van het Handvest. 220

De uitkomst van beide zaken lijkt gelijkaardig, maar het HvJ stelde zich ietwat soepeler op dan het EHRM. Het stelde bijvoorbeeld dat enkel wanneer ernstig moet worden gevreesd dat het systeem van de asielprocedure zal tekortschieten, er zich een effectieve schending van artikel 4 van het Handvest kan voordoen. ${ }^{\mathbf{2 2 1}}$ Het gevolg bleef desalniettemin hetzelfde; de EUwetgever trok zijn conclusies en voegde in de huidige Dublin III-verordening artikel 3.2 lid 2 in: 
'Indien het niet mogelijk is een verzoeker over te dragen aan de lidstaat die in de eerste plaats als verantwoordelijke lidstaat is aangewezen, omdat ernstig moet worden gevreesd dat de asiel procedure en de opvangvoorzieningen voor verzoekers in die lidstaat systeemfouten bevatten die resulteren in onmenselijke of vernederende behandelingen in de zin van artikel 4 van het Handvest van de grondrechten van de Europese Unie, blijft de lidstaat die met het bepalen van de verantwoordelijke lidstaat is belast de criteria van hoofdstuk III onderzoeken teneinde vast te stellen of een andere lidstaat als verantwoordelijke lidstaat kan worden aangewezen. ${ }^{222}$

52. Individuele situatie - Dit artikel hield lange tijd stand en kon veel overdrachten aan bijvoorbeeld Griekenland verhinderen. ${ }^{223}$ In 2014 breidde het EHRM een vervolg aan M.S.S. en velde het een oordeel in de zaak Tarakhel t. Zwitserland. ${ }^{\mathbf{2 2 4}}$ Uit deze zaak bleek duidelijk dat lidstaten altijd de individuele situatio ${ }^{\mathbf{2 2 5}}$ van de betrokkenen moeten onderzoeken en dat de overdracht moet opgeschort worden in geval er een reëel risico in verband met artikel 3 EVRM wordt vastgesteld. ${ }^{\mathbf{2 2 6}}$ Hiermee werd de bescherming van artikel 3 EVRM uitgebreid; wanneer een lidstaat een overdracht overweegt moet deze niet enkel systeemfouten, maar ook 'andere fouten van meer individuele aard' onderzoeken. ${ }^{\mathbf{2 2} 7}$ Het EHRM formuleert tevens dat wanneer een lidstaat de overdracht van een kind overweegt, deze lidstaat de grootste voorzichtigheid aan de dag moet leggen. ${ }^{\mathbf{2 2 8}}$ Alvorens de overdracht plaatsvindt, moet de verantwoordelijke lidstaat bovendien eerst garanderen dat de kinderen een opvang zullen krijgen die onder meer aangepast is aan hun leeftijd. ${ }^{\mathbf{2 2 9}}$

53. Geen spoor in Dublin IV - Van deze rechtspraak is echter geen spoor terug te vinden in artikel 3 van het Dublin IVvoorstel. ${ }^{\mathbf{2 3 0}}$ Het voorstel is identiek aan het huidige artikel (Dublin III) en beperkt zich bijgevolg nog steeds tot systeemfouten. In de zaak C.K. heeft het HvJ ondertussen op zijn beurt ook geoordeeld dat niet enkel systeemfouten onder de bescherming van artikel 3 van de Dublinverordening vallen. ${ }^{\mathbf{2 3 1}}$ De EU-wetgever koos er eerder voor om de M.S.S.- en de N.S.-rechtspraak om te zetten in artikel 3 Dublin III. Het zou dus consistent zijn dat de Tarakhel- en de C.K.-rechtspraak hun weerslag vinden in de toekomstige wetgeving. ${ }^{\mathbf{2 3 2}}$ Het Europees Parlement volgde deze stelling en heeft de verwijzing naar systeemfouten geschrapt. ${ }^{\mathbf{2 3 3}}$ Dit is in het voordeel van de NBMV; op die manier kunnen de rechten van de NBMV beter onderzocht worden als er zich een overdracht mocht voordoen. ${ }^{\mathbf{2 3 4}}$

\section{§2. Dublinoverdrachten en het belang van het kind}

54. Verantwoordelijke lidstaat en de NBMV - Het Dublin IV-voorstel bevat vervolgens enkele artikelen met betrekking tot het bepalen van de verantwoordelijke lidstaat in het geval van de NBMV. Hierbij moet een onderscheid gemaakt worden naargelang de NBMV elders in een EU-lidstaat gezinsleden heeft of niet.

55. Controle vermogen en verwantschap - Wanneer de NBMV elders in de EU wél een gezinslid heeft, legt artikel 10 van het voorstel de verantwoordelijkheid voor de NBMV bij de lidstaat waar dat gezinslid zich wettig ophoudt, voor zover dat in het belang van de NBMV is. ${ }^{235}$ Hierbij is volgens het voorstel een beoordeling van het vermogen van het gezinslid nodig; op basis van een individueel onderzoek moet vaststaan dat het gezinslid voor hem kan zorgen. ${ }^{\mathbf{2 3 6}}$ Daarnaast moet ook de verwantschap bewezen worden. ${ }^{\mathbf{2 3 7}}$ De beoordeling van het vermogen en de verwantschap is vandaag verder geregeld in de

Uitvoeringsverordening bij de Dublinverordening. ${ }^{238}$ Deze Uitvoeringsverordening bepaalt echter geen criteria die kunnen helpen bij het uitvoeren van deze verplichtingen. ${ }^{399}$ Gezien de complexiteit en de gevoeligheid van de materie zou het nochtans beter zijn moest hieromtrent meer duidelijkheid bestaan. ${ }^{\mathbf{2 4 0}}$ Binnen de GEAS-hervormingen is echter nog geen voorstel opgenomen tot aanpassing van de Uitvoeringsverordening of tot het verduidelijken van deze verplichtingen.

56. De 'eerste lidstaat' - Onder de huidige wetgeving is het zo dat wanneer de NBMV géén familie heeft in een andere lidstaat, de lidstaat waarbij de NBMV zijn verzoek om internationale bescherming heeft ingediend de verantwoordelijke lidstaat is (art. 8 lid 4 Dublin III). ${ }^{\mathbf{2 4 1}}$ Het Dublin IV-voorstel wijzigt deze bepaling en stelt dat de verantwoordelijke lidstaat die lidstaat is waarbij de NBMV zijn verzoek om internationale bescherming het eerst heeft ingediend (art. 10 lid 5 Dublin IV). ${ }^{\mathbf{2 4 2}}$ De enige uitzondering hierop geldt wanneer wordt aangetoond dat 'dit niet in het belang van het kind is'. Wanneer een NBMV verschillende asielaanvragen heeft ingediend en zich niet meer in de lidstaat van het eerste verzoek bevindt, zal hij dus in principe worden overgedragen.

57. Ratio en weerlegging - Het doel van deze bepaling zou zijn dat wanneer de NBMV wordt teruggestuurd naar de lidstaat waar hij het eerste verzoek heeft ingediend, dit hem ontmoedigt om irregulier door te reizen naar een andere lidstaat. ${ }^{\mathbf{2 4 3}}$ Nochtans zou dat doel ook bereikt kunnen worden wanneer de NBMV effectief wordt opgevangen in de lidstaat waar hij zich bevindt en deze lidstaat hem een vertegenwoordiger garandeert. ${ }^{\mathbf{2 4 4}}$ De vertegenwoordiger zou hem dan begeleiden doorheen de asielprocedure en hij zou erop kunnen toezien dat de NBMV niet verder doorreist. Verschillende partijen zijn het dan ook niet eens met het Commissievoorstel en stellen dat ook de lidstaat waar de NBMV zich bevindt, verantwoordelijk moet kunnen zijn, om de overdracht te vermijden. ${ }^{\mathbf{2 4 5}}$

Artikel 10 lid 5 staat bovendien wat haaks op de eerdere rechtspraak van het HvJ in de M.A.-zaak. ${ }^{\mathbf{2 4 6}}$ Hierin werd namelijk vooropgesteld dat de verantwoordelijke lidstaat de lidstaat is waar de NBMV zich bevindt nadat hij er een verzoek om internationale bescherming heeft ingediend. Hij moet dus niet teruggestuurd worden naar de lidstaat waar hij zijn eerste verzoek had ingediend. Omwille van de kwetsbaarheid van de NBMV is het belangrijk om de Dublinprocedure niet nodeloos te rekken en dit impliceert dat de NBMV in principe niet aan een andere lidstaat mag worden overgedragen, gezien de lange termijnen waarmee een overdracht gepaard gaat. ${ }^{247}$ Het Hof verwees naar artikel 24.2 van het EU-Handvest en oordeelde hier meer bepaald dat het belang van het kind wel degelijk de eerste overweging is bij de vaststelling van de verantwoordelijke lidstaat onder de Dublinverordening. ${ }^{\mathbf{2 4 8}}$ Het zou in beginsel niet in het belang van de NBMV zijn mocht hij worden overgedragen. ${ }^{\mathbf{2 4 9}}$ 58. Voorstel Europees Parlement - Het Europees Parlement kan zich niet vinden in het voorstel van de Europese Commissie en stelt voor om de bepalingen in verband met het aanduiden van een verantwoordelijke lidstaat aan te passen. ${ }^{\mathbf{2 5 0}}$ Het Parlement kiest in feite voor een radicaal andere benadering. Er wordt niet langer gekeken naar waar de NBMV precies een verzoek heeft ingediend, zoals in de huidige Verordening en in het Commissievoorstel het geval is. Terwijl de NBMV onder het Commissievoorstel nog als een aparte categorie werd behandeld, valt de NBMV voor het Parlement onder het algemeen toewijzingsmechanisme. Voor het Parlement maakt het met andere woorden niet uit waar de NBMV een verzoek heeft ingediend. Als waarborg garandeert het Parlement dat 'elke beslissing over de verantwoordelijke lidstaat moet worden voorafgegaan door een multidisciplinaire beoordeling van het belang van het kind, ook in het geval van toewijzing'.251

Concreet stelt het Parlement voor om op basis van de reeds beschreven referentiesleutel een lijst op te maken van vier lidstaten met het laagste aantal verzoekers in verhouding tot hun referentieaantal. ${ }^{\mathbf{2 5 2}} \mathrm{Er}$ wordt dus gekeken naar welke vier lidstaten het kleinste aantal aanvragen behandelen in functie van hun BBP en aantal inwoners. Uit deze lijst moet de NBMV vervolgens één lidstaat kiezen. Het gevolg hiervan is hoogstwaarschijnlijk dat er zich nog meer overdrachten met NBMVs zullen voordoen. Waar de Europese Commissie M.A. reeds leek te negeren, lijkt het wel alsof deze zaak aan het Europees Parlement volledig voorbijgegaan is. De zaak M.A. stelde immers dat een overdracht in beginsel niet in het belang van het kind is. Een 'multidisciplinaire beoordeling van het belang van het kind' zou volgens de principes uit de rechtspraak dus altijd moeten leiden tot een weigering van overdracht. Dit onder andere doordat men zou kunnen stellen dat de Dublinprocedure op die manier nodeloos wordt gerekt. 
59. Lidstaat waar de NBMV aanwezig moet zijn - Ook is het zo dat, in tegenstelling tot wat geldt onder de huidige Verordening, ${ }^{253}$ enkel de lidstaat waar de NBMV aanwezig moet zijn, de plicht heeft om te garanderen dat de NBMV in alle procedures vergezeld is van zijn vertegenwoordiger. ${ }^{\mathbf{2 5 4}}$ Een vertegenwoordiger begeleidt de NBMV, hij beschikt over de nodige kwalificaties en expertise om ervoor te zorgen dat rekening gehouden wordt met het belang van de NBMV tijdens de Dublinprocedure. ${ }^{255}$

De vertegenwoordiger speelt dus een zeer belangrijke rol bij de bescherming van de rechten van de NBMV. Wanneer een NBMV zich echter volgens het voorstel in een 'verkeerde' lidstaat bevindt, dan loopt hij het risico dat zijn recht op vertegenwoordiging niet gegarandeerd wordt. ${ }^{\mathbf{2 5}}$ Het is aangewezen dat het voorstel hier gewijzigd wordt zodat elke lidstaat deze rechten moet garanderen. ${ }^{257}$ Het Europees Parlement ging hierop in en gaf aan dat elke lidstaat waar de minderjarige aanwezig is (in plaats van 'moet zijn') voor een vertegenwoordiger moet zorgen. ${ }^{258}$

\section{Afdeling III. Suggesties}

6o. Bepalingen in het algemeen strijdig met belang van het kind - Een Dublinoverdracht van een NBMV zonder familieleden in de EU naar een land waar de opvangomstandigheden slecht kunnen zijn, zou zowel een schending van artikel 3 EVRM als van het belang van het kind uitmaken. ${ }^{259}$ Zo zouden het refoulementverbod en het verbod op foltering immers geschonden kunnen worden en zou de NBMV worden overgedragen, wat strijdig lijkt met het belang van het kind. Een overdracht van deze NBMV naar een lidstaat waar de opvangomstandigheden aanvaardbaar zijn, zou in beginsel enkel een schending van het belang van het kind kunnen uitmaken. ${ }^{260}$ Dit zowel onder het voorstel van de Commissie als van het Parlement. De NBMV wordt in beide gevallen namelijk nog steeds onnodig overgedragen.

Concreet stelde het Europees Economisch en Sociaal Comité (EESC) dan ook dat de bepalingen van het Dublinvoorstel in het algemeen in strijd zijn met het belang van de NBMV. Hij zou namelijk geen effectieve toegang hebben tot de procedure voor verzoeken om internationale bescherming. ${ }^{\mathbf{2 6 1}}$ Daarnaast wees het EESC erop dat de bepalingen van het voorstel onvoldoende de beoordeling van de individuele rechten van de NBMV garanderen, zoals vereist werd door de Tarakhel-rechtspraak en de regels in verband met het verbod op foltering. ${ }^{\mathbf{2 6 2}}$

61. Alternatieve oplossing - Willen de EU-regelgevers komaf maken met deze kritiek, dan zouden ze enkele veranderingen kunnen aanbrengen die meer aan de rechten van de NBMV tegemoetkomen. In de eerste plaats zouden de EU-regelgevers, zoals het Parlement voorstelt, de verwijzing naar systeemfouten kunnen schrappen. Zo zouden ze meer kunnen garanderen dat de grondrechten van de NBMV worden onderzocht alvorens deze wordt overgedragen. ${ }^{\mathbf{2 6 3}}$ Ten tweede zou ook de lidstaat waar de NBMV zich bevindt als verantwoordelijke lidstaat aangeduid kunnen worden. ${ }^{\mathbf{2 6 4}}$ Op die manier vermijdt de NBMV een overdracht en wordt de procedure niet nodeloos gerekt. In derde instantie zou de lidstaat waar de NBMV aanwezig is een vertegenwoordiger moeten aanduiden. ${ }^{\mathbf{2 6 5}}$ Enkel op die manier heeft de NBMV de garantie dat hij altijd over een vertegenwoordiger beschikt.

\section{Hoofdstuk II. Vrijheidsontneming}

62. Vrijheid, veiligheid en ... de NBMV? - Ook de vrijheidsontneming vormt een opvallend onderdeel van de hervorming. ${ }^{266}$ Eerst werpt dit hoofdstuk een licht op het recht op vrijheid en veiligheid, waarna vervolgens opnieuw de kritieke punten in verband met de mensenrechten van de NBMV onder de loep worden genomen.

\section{Afdeling I. Kritiek}

\section{§1. Artikel 9 Voorstel Opvangrichtlijn}

63. Juridische en passende bijstand - Een van de basisvoorwaarden uit het Kinderrechtenverdrag is dat het kind in detentie het recht heeft om onverwijld te beschikken over juridische en andere passende bijstand. ${ }^{\mathbf{2 6} 7}$ In artikel 9 van het Commissievoorstel voor de Opvangrichtlijn worden de waarborgen voor asielzoekers in bewaring opgelijst en wordt gestipuleerd dat de rechtmatigheid van de bewaring door de rechter met spoed moet worden getoetst. ${ }^{\mathbf{2 6 8}}$ Er zijn in dit artikel echter geen aangepaste bepalingen voor het kind of de NBMV terug te vinden. Wel is het zo dat in artikel 2 lid 12 van het voorstel verwezen wordt naar het voorstel voor een Procedureverordening. In deze verordening wordt gewaarborgd dat de NBMV een vertegenwoordiger moet worden toegewezen. Deze vertegenwoordiger moet de NBMV ook in de juridische procedures vertegenwoordigen. ${ }^{\mathbf{2 6 9}}$

64. Informatie in een begrijpelijke taal - Daarnaast ontbreekt verdere duidelijkheid rond het recht van het kind in het kader van informatie rond de detentie. ${ }^{270}$ Artikel 5 lid 2 EVRM stipuleert dat wie gearresteerd ${ }^{271}$ is onverwijld, in een taal die hij verstaat, op de hoogte gebracht moet worden van de redenen van zijn arrestatie en van alle beschuldigingen die tegen hem ingebracht zijn. Het EHRM oordeelde dat dit recht inhoudt dat de informatie simpel, niet-technisch en eenvoudig te begrijpen moet zijn. ${ }^{272}$ Bovendien gaf het Hof in Z.H. aan dat op een adequate manier rekening gehouden moet worden met de persoonlijke karakteristieken van de verzoeker, zoals een geestesstoornis. ${ }^{273}$

Deze elementen zijn niet in het voorstel terug te vinden, het voorstel geeft enkel aan dat de informatie schriftelijk en in een begrijpelijke taal moet worden gegeven. ${ }^{274}$ Het stipuleert bijvoorbeeld niet dat de informatie aangepast moet zijn aan de leeftijd van het kind of aan het opleidingsniveau van het kind, zodat op een adequate manier rekening gehouden kan worden met zijn karakteristieken. ${ }^{275}$ Een bijkomende opmerking is dat artikel 9 weergeeft dat de informatie schriftelijk moet worden gegeven, terwijl een kind niet altijd kan lezen. ${ }^{\mathbf{2 7 6}}$ Het EHRM geeft aan dat wanneer een verzoeker niet in staat is om de informatie te ontvangen, deze moet worden meegedeeld aan iemand die hem wettig vertegenwoordigt. ${ }^{277}$ In ieder geval onderlijnt dit gegeven nogmaals het belang van de aanwezigheid van een vertegenwoordiger voor de NBMV, gezien hij zelf niet altijd kan lezen en hij de informatie dus niet noodzakelijk altijd kan ontvangen of begrijpen.

Het Europees Parlement schrapte enkele onderdelen van artikel 9 uit het Commissievoorstel, maar stelde geen wijzigingen voorop die de rechten van de NBMV in deze situatie meer zouden verduidelijken. ${ }^{278}$ Dit mede doordat het Europees Parlement voorstelt om detentie van minderjarigen eenvoudigweg af te schaffen en deze rechten onder zijn visie dan ook niet meer gegarandeerd hoeven te worden. Als de NBMV niet meer in detentie kan gehouden worden, moet hij rond detentie natuurlijk geen informatie meer ontvangen.

\section{§2. Artikel 11 Voorstel Opvangrichtlijn}

65. Bewaring als uitzonderlijke maatregel: duidelijkheid - Daarnaast voorziet het voorstel van de Opvangrichtlijn ook specifiek in een bepaling rond de bewaring van NBMVs. Het huidige artikel 11 lid 3 bepaalt het volgende: 'Niet-begeleide minderjarigen worden alleen in uitzonderlijke omstandigheden in bewaring gehouden. Alles wordt in het werk gesteld om de bewaring van niet-begeleide minderjarigen zo spoedig mogelijk op te heffen.' ${ }^{\mathbf{2 7 9}}$ Deze bepaling, die dateert van 2013, werd 
letterlijk overgenomen in het Commissievoorstel van 2016. Dit is enigszins opmerkelijk, want in het Commissievoorstel van 2008 voor de richtlijn van 2013 werd eerst nog opgenomen dat minderjarigen in 'geen geval in bewaring worden gehouden'. ${ }^{\mathbf{2 8 0}}$ Bovendien verzet het European Council for Refugees and Exiles (ECRE) zich sterk tegen deze bepaling. Meer bepaald spoort ECRE aan tot het amenderen van artikel 11 zodat een uitzondering wordt voorzien voor personen met bijzondere opvangnoden, zoals de NBMV. ${ }^{\mathbf{2 8 1}}$ Dit zou in lijn zijn met de rechtspraak van het EHRM. Het Hof oordeelde eerder namelijk dat de karakteristieken van detentie de kwetsbaarheid van kinderen enkel zouden versterken en dat kinderen in principe niet in detentie gehouden mogen worden, omdat de omgeving waarin ze terechtkomen niet overeenstemt met het belang van het kind. ${ }^{\mathbf{2 8 2}}$ Ook geeft de UNHCR hier duidelijk aan dat 'As a general rule, unaccompanied or separated children should not be detained'. ${ }^{\mathbf{2 8 3}}$ Desalniettemin lijkt artikel 11 lid 3 van het voorstel wél aan de basisvoorwaarde in verband met duidelijkheid uit artikel 37 van het Kinderrechtenverdrag te voldoen. ${ }^{\mathbf{2 8}}$ Deze voorwaarde houdt immers in dat de detentie volgens een duidelijke, nietarbitraire, wet moet gebeuren en dat het slechts een uitzonderlijke maatregel kan zijn, voor een zo kort mogelijke periode. ${ }^{\mathbf{2 8 5}}$ De maatregel uit artikel 11 is duidelijk opgesteld en geeft letterlijk aan dat een detentie slechts in uitzonderlijke omstandigheden kan gebeuren en dat alles in het werk wordt gesteld om de bewaring zo snel mogelijk op te heffen.

66. Omstandigheden van de detentie - Verderop wordt in artikel 11 van het Commissievoorstel (2016) gestipuleerd dat NBMVs nooit in een gevangenis in bewaring mogen worden gehouden; ze moeten worden ondergebracht in opvangcentra met aangepaste faciliteiten, met personeel dat rekening houdt met hun rechten, en afgescheiden van volwassenen. ${ }^{\mathbf{2 8 6}}$ Hoewel dit gegeven reeds in grote mate voldoet aan de basisvoorwaarde in verband met de omstandigheden van detentie, moeten er toch enkele opmerkingen gemaakt worden. ${ }^{\mathbf{2 8} 7}$ Dit artikel geeft alvast duidelijk aan dat er rekening gehouden moet worden met de behoeften en de leeftijd van het kind, maar er wordt niet bepaald waar de NBMV ondergebracht moet worden als er geen dergelijke opvangcentra zijn, of wanneer er in die centra onvoldoende plaats is. ${ }^{\mathbf{2 8 8}}$ Dat er onvoldoende plaats beschikbaar is, is vandaag namelijk in verschillende lidstaten nog steeds een probleem. ${ }^{\mathbf{2 8 9}}$

Bovendien wordt er, zoals vereist is door artikel 37 lid c Kinderrechtenverdrag, voorzien dat een NBMV in bewaring onderwijs moet kunnen genieten. ${ }^{\mathbf{2 9 0}}$ Artikel 11 lid 6 van het Commissievoorstel laat hierop echter uitzonderingen toe in transitzones. Het EHRM heeft daaromtrent in het verleden al bevestigd dat ook het verblijf van een vreemdeling in transitzones of grenshospita onder het bereik van artikel 5 EVRM valt. ${ }^{291}$ Moest de NBMV toch nog in detentie gehouden worden, lijkt volgens critici een aanpassing van artikel 11 lid 6 bijgevolg aangewezen. ${ }^{292}$

67. Visie van het Europees Parlement en praktijk - Het Parlement stelde in zijn amendementen dat er een verbod zou moeten komen op de detentie van kinderen, ook van kinderen die niet begeleid zijn. ${ }^{293}$ Volgens amendement 64 zouden de lidstaten in plaats van detentie 'passende zorgvoorzieningen' moeten garanderen. Bijgevolg wil het Parlement ook artikel 11 lid 6 aanpassen, aangezien het recht op onderwijs in detentie eenvoudigweg niet gegarandeerd moet worden als er geen detentie is. ${ }^{294}$ In de lidstaten is de detentiepraktijk in ieder geval verdeeld. ${ }^{295}$ De onderstaande tabel geeft een overzicht van de detentie van NBMVs in enkele lidstaten weer.

FIGUUR 3: Detentiepraktijk van enkele EU-lidstaten in verband met NBMVs (selectie)

\begin{tabular}{|l|l|l|l|}
\hline Locatie & Worden NBMVs in praktijk vastgehouden? & \multicolumn{2}{l|}{} \\
\hline & Regelmatig & Zelden & Nooit \\
\hline België & & $\mathrm{X}$ & \\
\hline Frankrijk & & $\mathrm{X}$ & \\
\hline Griekenland & $\mathrm{X}$ & & $\mathrm{X}$ \\
\hline Ierland & & & \\
\hline Italië & & $\mathrm{X}$ & \\
\hline Nederland & & $\mathrm{X}$ & $\mathrm{X}$ \\
\hline Polen & & & \\
\hline Portugal & $\mathrm{X}$ & & \\
\hline
\end{tabular}

Bron: Asylum Information Database (AIDA) ${ }^{296}$

\section{Afdeling II. Suggesties}

68. Meer optimale oplossing - Ook hier kunnen de EU-regelgevers een tandje bij steken. In eerste instantie zou er, zoals ook het Europees Parlement voorstelt, een verbod kunnen komen op de detentie van de NBMV en zouden de lidstaten voor de NBMV in alternatieve zorgvoorzieningen kunnen voorzien. ${ }^{\mathbf{2 9 7}}$ Mocht dit verbod er niet komen, zouden de omstandigheden van detentie voor de NBMV verduidelijkt kunnen worden en zou hem altijd onderwijs gegarandeerd moeten worden, ook in transitzones. ${ }^{\mathbf{2 9 8}}$ Ook zouden de regelgevers de juridische bijstand en het recht op informatie rond zijn detentie voor de NBMV dan kunnen verduidelijken. ${ }^{299}$

\section{Hoofdstuk III. Deelbesluit}

69. Overdrachten van de NBMV - Een van de belangrijkste onderdelen van het GEAS is het Dublinsysteem. Na enkele uitspraken van de Europese hoven die dit systeem in vraag stelden, leek het voor de EU-regelgevers tijd om het te herzien. Deze opgave bleek allesbehalve gemakkelijk. In de eerste plaats rijzen er vragen met betrekking tot het verbod op foltering en het refoulementverbod. Zowel het HvJ als het EHRM zijn het erover eens dat ook Europese overdrachten hiervan een schending kunnen uitmaken. Nochtans oordeelde de Europese Commissie hier anders over en hield ze vast aan de beperking tot het onderzoeken van 'systeemfouten'. Het Europees Parlement bleek alerter en opperde om deze beperking af te schaffen. Zo moeten de lidstaten alvorens ze een NBMV overdragen niet enkel systeemfouten onderzoeken, maar ook de individuele bescherming van zijn rechten nagaan.

Vervolgens zijn ook de regels in verband met het bepalen van de verantwoordelijke lidstaat niet gespaard van kritiek. Wanneer een NBMV elders in de EU een gezinslid heeft, wordt hij naar deze lidstaat overgebracht na een controle van vermogen en verwantschap. Rond deze complexe controle wordt echter weinig begeleiding gegeven vanuit de Commissie. Wanneer de NBMV langs de andere kant geen gezinslid heeft in de EU, behandelt volgens de Commissie het land van eerste aanvraag zijn verzoek, wat strijdig lijkt met de principes uit de rechtspraak. Het Parlement oordeelt daarentegen dat de NBMV onder het algemene 
toewijzingsregime moet kunnen vallen, wat de mogelijkheid tot nodeloze overdrachten doet toenemen. Tot slot stelt de Commissie voor dat enkel de lidstaat waar de NBMV aanwezig moet zijn, een vertegenwoordiger moet aanstellen. De vertegenwoordiger speelt voor de NBMV echter een cruciale rol, het Parlement leek dit te beseffen en het paste zijn voorstel hieraan aan.

70. Detentie en de NBMV - In tweede instantie moet er nog wat gesleuteld worden aan de bepalingen met betrekking tot het recht op vrijheid en veiligheid. Artikel 11 lid 3 van dit Voorstel (de bewaring van de NBMV) voldoet wel aan de vereisten van het Kinderrechtenverdrag, maar is, gezien de rechtspraak van de Europese hoven, kritiek. Het Parlement streeft naar een verbod op de detentie van minderjarigen, wat voor de NBMV een hogere graad van bescherming zou kunnen inhouden. Mochten er zich daarentegen toch nog detenties van NBMVs voordoen, zouden de EU-regelgevers een verduidelijking kunnen aanbrengen voor wat betreft de aan de NBMV aangepaste juridische bijstand. Ook zou artikel 11 lid 6 duidelijker kunnen zijn voor wat betreft de omstandigheden van detentie voor de NBMV en zou het recht op onderwijs in alle omstandigheden gegarandeerd moeten worden.

71. Niet op alle vlakken voldaan aan de mensenrechten - De voorstellen omtrent de regelgeving van het GEAS lijken dus niet op alle vlakken aan de mensenrechten van de NBMV tegemoet te komen. Voor wat betreft detentie en Dublinoverdrachten lijkt er nog een zekere weg te gaan.

\section{Besluit}

72. Richtsnoeren en meer coherentie - De groep NBMV is zeer heterogeen. De jongeren komen uit verschillende landen en hebben verschillende leeftijden, wat het niet eenvoudig maakt om één duidelijk statuut aan de NBMV toe te schrijven. Het is bijgevolg ook niet gemakkelijk om hen te omschrijven aan de hand van een definitie, maar de meerderheid is het erover eens dat het gaat om kinderen jonger dan 18 jaar, die zonder hun ouders in de EU toekomen en afkomstig zijn uit een land buiten de EU. Deze criteria lijken eenvoudig, maar blijken dat in praktijk niet te zijn. De NBMV komt namelijk vaak zonder documenten in Europa toe. Vooral de leeftijd van de kinderen kan daardoor moeilijk geschat worden en de EU-lidstaten vullen de leeftijdsbepaling verschillend in. Ook het land van oorsprong van de NBMV is niet altijd eenvoudig vast te stellen. Tot slot is het soms moeilijk om zijn familieleden op te sporen. Duidelijke richtsnoeren van de EU-regelgevers lijken hier welkom.

Daarenboven is het voor de NBMV zelf niet gemakkelijk om zich op zijn internationale rechten te beroepen, aangezien deze niet altijd rechtstreekse werking hebben. Bovendien liggen de rechtsregels verspreid over verschillende instrumenten. De NBMV moet hiertussen zelf zijn weg zoeken. Gezien de specifieke hoedanigheid van de NBMV is het voor de EU-regelgevers niet eenvoudig om één omvattende wettekst of richtsnoeren op te maken met betrekking tot deze groep kinderen, maar inspanningen daartoe zouden de NBMV alleen tot voordeel kunnen strekken. In ieder geval toont deze puzzel aan rechtsregels aan dat het erg belangrijk is dat de NBMV over een vertegenwoordiger beschikt. Toch lijkt het Commissievoorstel voor de Dublinverordening hem deze vertegenwoordiger niet altijd te garanderen.

73. De toekomst van de voorstellen - De Commissievoorstellen schieten ook op andere punten tekort en lijken niet overal te voldoen aan de mensenrechten van de NBMV. Op sommige vlakken lijkt het zelfs alsof zowel de Europese Commissie als het Europees Parlement de principes in verband met de rechten van het kind en de NBMV naast zich neerleggen. In beginsel zou de NBMV zo weinig mogelijk overgedragen mogen worden. De Dublinprocedure mag voor kinderen immers niet nodeloos gerekt worden. Daarom zou voor de NBMV meer soepelheid moeten bestaan betreffende het aanduiden van een verantwoordelijke lidstaat, zodat hij kan verblijven in de staat waar hij zich bevindt als hij elders in Europa geen familie heeft. Los daarvan is het erg belangrijk om een beperking tot het louter onderzoeken van 'systeemfouten' te schrappen. Mochten overdrachten met NBMVs toch noodzakelijk zijn, moet hen minstens een individuele beoordeling van hun rechten gegarandeerd worden en dat lijkt onmogelijk indien alleen 'systeemfouten' onderzocht moeten worden.

Daarnaast is het belangrijk om, wat de bepalingen in verband met vrijheidsontneming betreft, te voldoen aan de basisvoorwaarden uit het Kinderrechtenverdrag. Zo zouden onduidelijke regels rond de vrijheidsontneming beter verduidelijkt of eenvoudigweg geschrapt worden. Vervolgens zou de juridische bijstand beter afgestemd kunnen zijn op de NBMV. Het is aan te raden dat de Opvangrichtlijn hieromtrent meer concrete bepalingen bevat. Ook de omstandigheden van detentie van de NBMV verdienen een betere omschrijving. Detentie in aangepaste centra is vandaag de dag niet altijd te garanderen, de vraag blijft dan ook waar de NBMV wel terecht kan als daar geen plaats blijkt te zijn. Sommige lidstaten kiezen ervoor om de NBMV überhaupt niet op te sluiten. Het Europees Parlement schaarde zich achter deze visie en stelde een algemeen verbod op de detentie van kinderen voor.

Tot slot bleek uit dit onderdeel dat de notie 'het belang van het kind' zeer belangrijk is voor de NBMV. Door de vage formulering ervan is het voor de lidstaten echter niet altijd duidelijk hoe ze dit beginsel precies moeten toepassen op deze jongeren, wat leidt tot verschillende resultaten. Ook hier lijken richtsnoeren van de EU-regelgevers nuttig.

74. Overzicht - Op basis van de analyse van de GEAS-voorstellen met betrekking tot de Dublinprocedure en de Opvangrichtlijn, werd de volgende figuur opgesteld. In de rechterkolom wordt kort aangegeven waarop het eigen voorstel het meest gebaseerd is.

FIGUUR 5: Overzicht

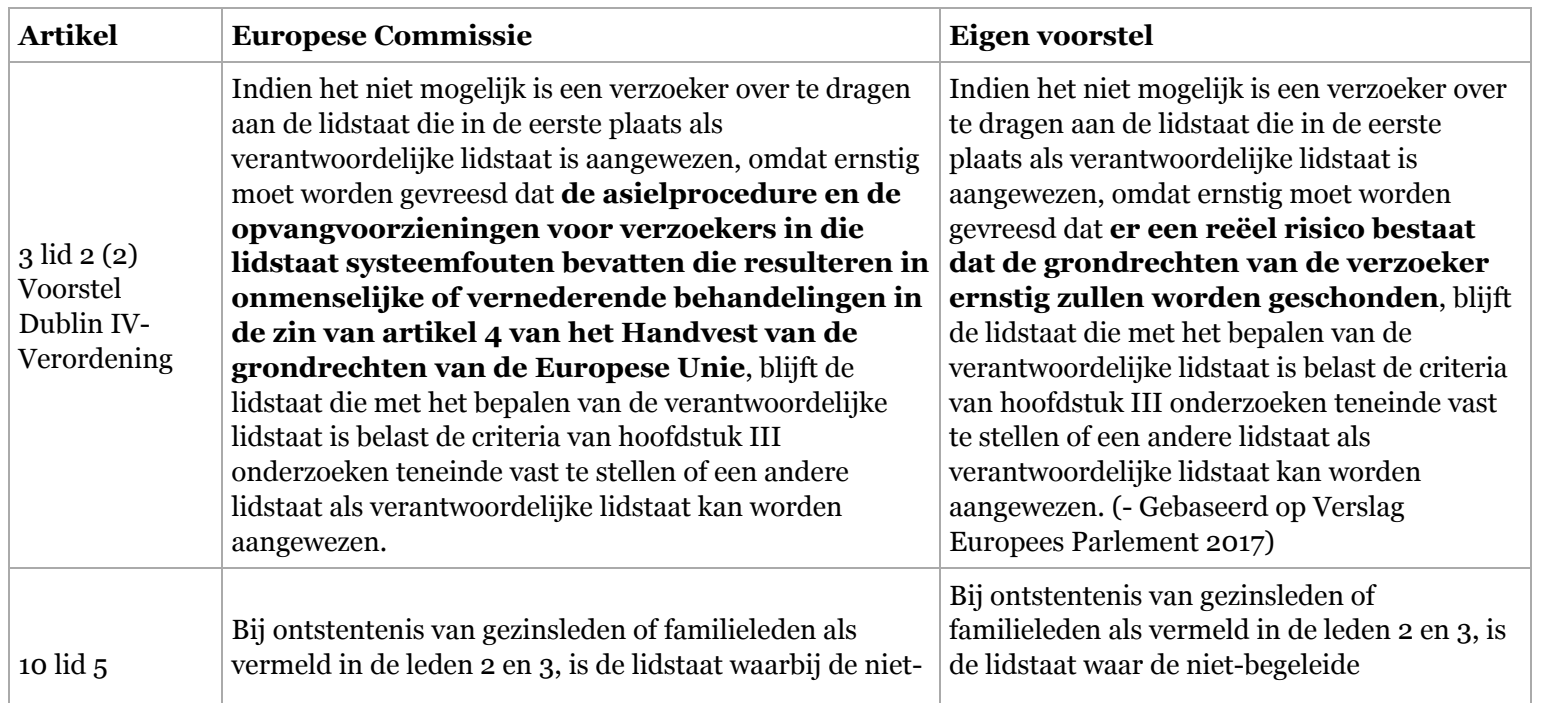




\begin{tabular}{|c|c|c|}
\hline \begin{tabular}{|l} 
Voorstel \\
Dublin IV- \\
Verordening
\end{tabular} & $\begin{array}{l}\text { begeleide minderjarige zijn verzoek om internationale } \\
\text { bescherming het eerst heeft ingediend de } \\
\text { verantwoordelijke lidstaat, tenzij wordt aangetoond dat } \\
\text { dit niet in het belang van de minderjarige is. }\end{array}$ & $\begin{array}{l}\text { minderjarige zich op dat moment bevindt } \\
\text { de verantwoordelijke lidstaat, tenzij wordt } \\
\text { aangetoond dat dit niet in het belang van de } \\
\text { minderjarige is. (- Gebaseerd op Advies CvdR } \\
\text { en Meijers Committee) }\end{array}$ \\
\hline $\begin{array}{l}8 \text { lid } 2 \text { Voorstel } \\
\text { Dublin IV- } \\
\text { Verordening }\end{array}$ & $\begin{array}{l}\text { Elke lidstaat zorgt ervoor dat, wanneer een niet- } \\
\text { begeleide minderjarige aanwezig moet zijn, de niet- } \\
\text { begeleide minderjarige bij de relevante procedures } \\
\text { waarin deze verordening voorziet, wordt } \\
\text { vertegenwoordigd en/of bijgestaan door een } \\
\text { vertegenwoordiger. }\end{array}$ & $\begin{array}{l}\text { Elke lidstaat zorgt ervoor dat, wanneer er een } \\
\text { niet-begeleide minderjarige aanwezig is, de } \\
\text { niet-begeleide minderjarige bij alle } \\
\text { procedures waarin deze verordening voorziet, } \\
\text { wordt vertegenwoordigd en/of bijgestaan door } \\
\text { een vertegenwoordiger. (- Gebaseerd op } \\
\text { Verslag Europees Parlement 2017) }\end{array}$ \\
\hline $\begin{array}{l}11 \text { lid } 3 \\
\text { Voorstel } \\
\text { Opvangrichtlijn }\end{array}$ & $\begin{array}{l}\text { Niet-begeleide minderjarigen worden alleen in } \\
\text { uitzonderlijke omstandigheden in bewaring } \\
\text { gehouden. Alles wordt in het werk gesteld om de } \\
\text { bewaring van niet-begeleide minderjarigen zo } \\
\text { spoedig mogelijk op te heffen. } \\
\text { Niet-begeleide minderjarigen worden nooit in } \\
\text { een gevangenis in bewaring gehouden. } \\
\text { Zij worden zoveel als mogelijk ondergebracht in } \\
\text { instellingen met personeel dat rekening houdt } \\
\text { met de rechten en noden van personen van hun } \\
\text { leeftijd en faciliteiten die zijn aangepast aan } \\
\text { niet-begeleide minderjarigen. } \\
\text { Ingeval niet-begeleide minderjarigen toch in } \\
\text { bewaring worden gehouden, zorgen de lidstaten } \\
\text { ervoor dat zij afgescheiden van volwassenen } \\
\text { worden gehuisvest. }\end{array}$ & $\begin{array}{l}\text { Niet-begeleide minderjarigen worden } \\
\text { in geen geval in bewaring gehouden. De } \\
\text { lidstaten zorgen in plaats daarvan voor } \\
\text { passende zorgvoorzieningen. (- } \\
\text { Gebaseerd op Voorstel Europese Commissie } \\
\text { Opvangrichtlijn 2008 en Verslag Europees } \\
\text { Parlement 2017) }\end{array}$ \\
\hline
\end{tabular}

\section{Bibliografie}

\section{Afdeling I. Wetgeving, voorbereidende werken, fact sheets en soft law}

\section{§1. Internationaal}

Algemene Vergadering van de Verenigde Naties, United Nations Rules for the Protection of Juveniles Deprived of their Liberty, Resolutie 45/113, 14 december 1990, https://www.ohchr.org/Documents/ProfessionalInterest/res45_113.pdf.

Internationaal Verdrag betreffende de Status van Vluchtelingen van 28 juli 1951.

Internationaal Verdrag inzake de Burgerrechten en Politieke Rechten van 16 december 1966.

Mondiaal Pact voor Veilige, Ordelijke en Reguliere Migratie van 11 juli 2018 (Migratiepact).

Protocol van New York betreffende de Status van Vluchtelingen van 31 januari 1967.

Status of the Convention on the Rights of the Child, https://treaties.un.org/pages/ViewDetails.aspx? src=TREATY\&mtdsg_no=IV-11\&chapter=4\&lang=en.

UN Committee on the Rights of the Child, General Comment No. 6 (2005): Treatment of Unaccompanied and Separated Children Outside Their Country of Origin, CRC/GC/2005/6, 27 p.

UN Committee on the Rights of the Child, General Comment No. 14 (2013): The Right of the Child to have his or her Best Interest Taken as a Primary Consideration, $\mathrm{CRC} / \mathrm{C} / \mathrm{GC} / 14,21 \mathrm{p}$.

UN High Commissioner for Refugees (UNHCR), Children on the Run, Unaccompanied Children leaving Central America and Mexico and the Need for International Protection, 2001, http://www.unhcr.org/about-us/background/56fc266f4/children-onthe-run-full-report.html.

UN High Commissioner for Refugees (UNHCR), Guidelines on Policies and Procedures in Dealing with Unaccompanied Children Seeking Asylum, februari 1997, 21 p., http://www.unhcr.org/publications/legal/3d4f91cf4/guidelines-policiesprocedures-dealing-unaccompanied-children-seeking-asylum.html.

UN High Commissioner for Refugees (UNHCR), Guidelines on the Applicable Criteria and Standards relating to the Detention of Asylum Seekers and Alternatives to Detention, 2012, https://www.unhcr.org/publications/legal/505b10eeg/unhcr-detentionguidelines.html.

UN High Commissioner for Refugees (UNHCR), Handbook and Guidelines on Procedures and Criteria for Determining Refugee Status (reissued), december 2011, https://www.unhcr.org/3d58e13b4.html. 
januari 2004, 71 p, http://www.unhcr.org/protection/children/4098b3172/inter-agency-guiding-principles-unaccompaniedseparated-children.html.

UN High Commissioner for Refugees (UNHCR), Note on Non-Refoulement (Submitted by the High Commissioner), 23 augustus 1997, http://www.unhcr.org/excom/scip/3ae68ccd1o/note-non-refoulement-submitted-high-commissioner.html.

UN High Commissioner for Refugees (UNHCR), States Parties to the Convention relating to the Status of Refugees and the 1967 Protocol, 5 p., http://www.unhcr.org/protection/basic/3b73bod63/states-parties-1951-convention-its-1967-protocol.html.

UN High Commissioner for Refugees (UNHCR), Vluchteling of migrant: terminologie, https://www.unhcr.org/be/wpcontent/uploads/sites/46/2018/o1/UNHCR-Terminologie-NL.pdf.

UN High Commissioner for Refugees (UNHCR), Working with Unaccompanied Children, A Community Based Approach, mei 1996, 97 p., http://www.refworld.org/docid/4a54bc24d.html.

UN Human Rights Council, Progress Report: Global Issue of Unaccompanied Migrant Children and Adolescents and Human Rights, 16 augustus 2016, $21 \mathrm{p}$.

UN Human Rights Council, Resolution on Unaccompanied Migrant Children and Adolescents, 1 juli 2015, 3 p., http://www.ohchr.org/EN/HRBodies/HRC/AdvisoryCommittee/Pages/UnaccompaniedMigrantChildren.aspx.

Universele Verklaring van de Rechten van de Mens van 10 december 1948.

Verdrag inzake de Rechten van het Kind van 20 november 1989 (Kinderrechtenverdrag).

Verdrag tegen foltering en andere wrede, onmenselijke en onterende behandeling of bestraffing van 10 december 1984 (Folterverdrag).

\section{§2. Europees}

Besluit 2001/258/EG van de Raad van 15 maart 2001 inzake de sluiting van een overeenkomst tussen de Europese Gemeenschap, de Republiek IJsland en het Koninkrijk Noorwegen betreffende de criteria en mechanismen voor de vaststelling van de staat die verantwoordelijk is voor de behandeling van een asielverzoek dat in een lidstaat, in IJsland of in Noorwegen wordt ingediend.

Besluit 2006/18/EG van de Raad van 21 februari 2006 betreffende de sluiting van de Overeenkomst tussen de Europese Gemeenschap en het Koninkrijk Denemarken houdende uitbreiding tot Denemarken van de bepalingen van Verordening (EG) nr. 343/2003 van de Raad tot vaststelling van de criteria en instrumenten om te bepalen welke lidstaat verantwoordelijk is voor de behandeling van een asielverzoek dat door een onderdaan van een derde land bij een van de lidstaten wordt ingediend en van Verordening (EG) nr. 2725/2000 van de Raad betreffende de instelling van 'Eurodac' voor de vergelijking van vingerafdrukken ten behoeve van een doeltreffende toepassing van de Overeenkomst van Dublin.

Besluit 2008/147/EG van de Raad van 28 januari 2008 betreffende de sluiting namens de Europese Gemeenschap van de Overeenkomst tussen de Europese Gemeenschap en de Zwitserse Bondsstaat inzake de criteria en mechanismen voor de vaststelling van de staat die verantwoordelijk is voor de behandeling van een asielverzoek dat in een lidstaat of in Zwitserland wordt ingediend.

Besluit 2011/351/EU van de Raad van 7 maart 2011 betreffende de sluiting van een Protocol tussen de Europese Gemeenschap, de Zwitserse Bondsstaat en het Vorstendom Liechtenstein betreffende de toetreding van het Vorstendom Liechtenstein tot de Overeenkomst tussen de Europese Gemeenschap en de Zwitserse Bondsstaat inzake de criteria en mechanismen voor de vaststelling van de staat die verantwoordelijk is voor de behandeling van een asielverzoek dat in een lidstaat of in Zwitserland wordt ingediend.

Chart of Signatures and Ratifications of Treaty o05 (Convention for the Protection of Human Rights and Fundamental Freedoms), https://www.coe.int/en/web/conventions/full-list/-/conventions/treaty/oo5/signatures?p_auth=h42ZKciw.

Europees Comité van de Regio's (CvdR), Advies rond de hervorming van het gemeenschappelijk Europees asielstelsel, 7-8 december 2016, CIVEX-VI/o13.

Europees Economisch en Sociaal Comité (EESC), Advies over het voorstel voor een richtlijn van het Europees Parlement en de Raad tot vaststelling van normen voor de opvang van verzoekers om internationale bescherming (herschikking), 10 maart 2017, C 75/97.

Europees Economisch en Sociaal Comité (EESC), Advies over het voorstel voor een verordening van het Europees Parlement en de Raad tot vaststelling van de criteria en instrumenten om te bepalen welke lidstaat verantwoordelijk is voor de behandeling van een verzoek om internationale bescherming dat door een onderdaan van een derde land of een staatloze bij een van de lidstaten wordt ingediend (herschikking), 2 februari 2017, C 34/144.

Europees Parlement, Ontwerpverslag over het voorstel voor een verordening van het Europees Parlement en de Raad tot vaststelling van de criteria en instrumenten om te bepalen welke lidstaat verantwoordelijk is voor de behandeling van een verzoek om internationale bescherming dat door een onderdaan van een derde land of een staatloze bij een van de lidstaten wordt ingediend (herschikking), 24 februari 2017.

Europees Parlement, Verslag over het voorstel voor een richtlijn van het Europees Parlement en de Raad tot vaststelling van normen voor de opvang van verzoekers om internationale bescherming (herschikking), 10 mei 2017, A8-0186/2017.

Europees Parlement, Verslag over het voorstel voor een verordening van het Europees Parlement en de Raad tot vaststelling van de criteria en instrumenten om te bepalen welke lidstaat verantwoordelijk is voor de behandeling van een verzoek om internationale bescherming dat door een onderdaan van een derde land of een staatloze bij een van de lidstaten wordt 
ingediend (herschikking), 6 november 2017, A8-0345/2017.

Europees Verdrag ter voorkoming van Foltering en Onmenselijke of Vernederende Behandeling of Bestraffing van 26 november 1987.

Europees Verdrag voor de Rechten van de Mens van 3 september 1953.

Europese Commissie, Aanbeveling gericht tot de Helleense Republiek over de door Griekenland te nemen specifieke dringende maatregelen met het oog op de hervatting van overdrachten uit hoofde van Verordening (EU) nr. 604/2013 van het Europees Parlement en de Raad, 28 september 2016, L 286/75.

Europese Commissie, Actieplan EU niet-begeleide minderjarigen (2010-2014), 17 p.,

https://www.rijksoverheid.nl/documenten/richtlijnen/2011/o7/o7/actieplan-eu-niet-begeleide-minderjarigen-2010-2014.

Europese Commissie, Communicatie naar het Europees Parlement en de Raad, Towards a Reform of The Common European Asylum System and Enhancing Legal Avenues to Europe, 6 april 2016, COM(2016) 197 final.

Europese Commissie, Voorstel voor een richtlijn van het Europees Parlement en de Raad, tot vaststelling van minimumnormen voor de opvang van asielzoekers in de lidstaten (herschikking), 3 december 2008, COM(2008) 815 final.

Europese Commissie, Voorstel voor een richtlijn van het Europees Parlement en de Raad, tot vaststelling van normen voor de opvang van verzoekers om internationale bescherming (herschikking), 13 juli 2016, COM(2016) 465 final (Voorstel Opvangrichtlijn).

Europese Commissie, Voorstel voor een verordening van het Europees Parlement en de Raad, betreffende de instelling van 'Eurodac' voor de vergelijking van vingerafdrukken ten behoeve van een doeltreffende toepassing van [Verordening (EU) nr. $604 / 2013$ tot vaststelling van de criteria en instrumenten om te bepalen welke lidstaat verantwoordelijk is voor de behandeling van een verzoek om internationale bescherming dat door een onderdaan van een derde land of een staatloze bij een van de lidstaten wordt ingediend], voor de identificatie van een illegaal verblijvende onderdaan van een derde land of staatloze en betreffende verzoeken van rechtshandhavingsinstanties van de lidstaten en Europol om vergelijkingen van Eurodac-gegevens ten behoeve van rechtshandhaving (herschikking), 4 mei 2016, COM(2016) 272 final (Eurodac).

Europese Commissie, Voorstel voor een verordening van het Europees Parlement en de Raad, inzake het Asielagentschap van de Europese Unie en tot intrekking van Verordening (EU) nr. 439/2010, 4 mei 2016, COM(2016) 271 final.

Europese Commissie, Voorstel voor een verordening van het Europees Parlement en de Raad, inzake normen voor de erkenning van onderdanen van derde landen of staatlozen als personen die internationale bescherming genieten, voor een uniforme status voor vluchtelingen of voor personen die in aanmerking komen voor subsidiaire bescherming, en voor de inhoud van de verleende bescherming, alsook tot wijziging van Richtlijn 2003/109/EG van de Raad van 25 november 2003 betreffende de status van langdurig ingezeten onderdanen van derde landen, 13 juli 2016, COM(2016) 466 final (Voorstel Kwalificatieverordening).

Europese Commissie, Voorstel voor een verordening van het Europees Parlement en de Raad, tot vaststelling van de criteria en instrumenten om te bepalen welke lidstaat verantwoordelijk is voor de behandeling van een verzoek om internationale bescherming dat door een onderdaan van een derde land of een staatloze bij een van de lidstaten wordt ingediend (herschikking), 4 mei 2016, COM(2016) 270 final (Dublin IV).

Europese Commissie, Voorstel voor een verordening van het Europees Parlement en de Raad tot vaststelling van een gemeenschappelijke procedure voor internationale bescherming in de Unie en tot intrekking van Richtlijn 2013/32/EU, 13 juli 2016, $\operatorname{COM(2016)~} 467$ final (Voorstel Procedureverordening).

Europese Commissie, Questions \& Answers: Reforming the Common European Asylum System, 4 mei 2016, MEMO/16/1621.

Europese Raad, Conclusie, 28 juni 2018, EUCO 9/18.

Europese Raad, Conclusies van het voorzitterschap van de Europese Raad van Tampere, 15 en 16 oktober 1999.

Europese Raad, Het Programma van Stockholm - Een open en veilig Europa ten dienste en ter bescherming van de burger, 4 mei 2010, 2010/C 115/01.

Handvest van de Grondrechten van de Europese Unie, 18 december 2000, 2000/C 364/01.

Meijers Committee, Note on the proposed reforms of the Dublin Regulation (COM(2016) 197), the Eurodac recast proposal (COM(2016) 272 final) and the proposal for an EU Asylum Agency (COM(2016) 271 final), 2016.

Onderzoeksdienst van het Europees Parlement (EPRS), Reform of the Dublin System, 1 maart 2019, PE 586.639.

Raad van de Europese Unie, Nota, 2 juni 2017, 9781/17.

Raad van de Europese Unie, Nota, 6 oktober 2017, 12802/17.

Raad van de Europese Unie, Nota, 30 mei 2018, 9520/18.

Raad van de Europese Unie, Nota, 27 november 2018, 14597/18.

Raad van de Europese Unie, Nota, 26 februari 2019, 660o/19.

Resolutie van de Raad nr. C 274/13 van 20 juni 1995 over minimumwaarborgen voor asielprocedures. 
Resolutie van de Raad nr. 97/C 221/o3 van 26 juni 1997 inzake niet-begeleide minderjarige onderdanen van derde landen.

Richtlijn 2001/55/EG van de Raad van 20 juli 2001, betreffende minimumnormen voor het verlenen van tijdelijke bescherming in geval van massale toestroom van ontheemden en maatregelen ter bevordering van een evenwicht tussen de inspanning van de lidstaten voor de opvang en het dragen van de consequenties van de opvang van deze personen.

Richtlijn 2003/9/EG van de Raad van 27 januari 2003, tot vaststelling van minimumnormen voor de opvang van asielzoekers in de lidstaten.

Richtlijn 2003/86/EG van de Raad van 22 september 2003 inzake het recht op gezinshereniging.

Richtlijn 2004/81/EG van de Raad van 29 april 2004, betreffende de verblijfstitel die in ruil voor samenwerking met de bevoegde autoriteiten wordt afgegeven aan onderdanen van derde landen die het slachtoffer zijn van mensenhandel of hulp hebben gekregen bij illegale immigratie.

Richtlijn 2011/36/EU van de Raad van 5 april 2011, inzake de voorkoming en bestrijding van mensenhandel en de bescherming van slachtoffers daarvan, en ter vervanging van Kaderbesluit 2002/629/JBZ van de Raad.

Richtlijn 2011/95/EU van de Raad van 13 december 2011, inzake normen voor de erkenning van onderdanen van derde landen of staatlozen als personen die internationale bescherming genieten, voor een uniforme status voor vluchtelingen of voor personen die in aanmerking komen voor subsidiaire bescherming, en voor de inhoud van de verleende bescherming.

Richtlijn 2013/32/EU van de Raad van 26 juni 2013, betreffende gemeenschappelijke procedures voor de toekenning en intrekking van de internationale bescherming (herschikking).

Richtlijn 2013/33/EU van de Raad van 26 juni 2013, tot vaststelling van normen voor de opvang van verzoekers om internationale bescherming (herschikking).

Toelichtingen bij het Handvest van de Grondrechten, 14 december 2007, 2007/C 303/o2.

Uitvoeringsverordening, nr. 118/2014 van de Commissie van 30 januari 2014 tot wijziging van Verordening (EG) nr. 1560/2003 houdende uitvoeringsbepalingen van Verordening (EG) nr. 343/2003 van de Raad tot vaststelling van de criteria en instrumenten om te bepalen welke lidstaat verantwoordelijk is voor de behandeling van een asielverzoek dat door een onderdaan van een derde land bij een van de lidstaten wordt ingediend.

Verdrag betreffende de werking van de Europese Unie (VWEU) van 26 oktober 2012.

Verdrag van de Raad van Europa inzake de bestrijding van Mensenhandel van 16 mei 2005.

Verordening (EU), nr. 604/2013 van de Raad van 26 juni 2013 tot vaststelling van de criteria en instrumenten om te bepalen welke lidstaat verantwoordelijk is voor de behandeling van een asielverzoek dat door een onderdaan van een derde land bij een van de lidstaten wordt ingediend (Dublin III).

\section{§3. Andere}

Programmawet (I) 24 december 2002 Titel XIII Hoofdstuk VI: Voogdij over niet-begeleide minderjarige vreemdelingen, B.S. 31 december 2002.

\section{Afdeling II. Rechtspraak}

\section{§1. Europees Hof voor de Rechten van de Mens}

EHRM 21 februari 1975, nr. 4451/70, Golder/Verenigd Koninkrijk.

EHRM 25 april 1978, nr. 5856/72, Tyrer/Verenigd Koninkrijk.

EHRM 18 december 1986, nr. 9990/82, Bozano/Frankrijk.

EHRM 7 juli 1989, nr. 14038/88, Soering/Verenigd Koninkrijk.

EHRM 21 februari 1990, nr. 11509/85, Van Der Leer/Nederland.

EHRM 30 augustus 1990, nrs. 12244/86, 12245/86, 12383/86, Fox, Campbell en Hartley/Verenigd Koninkrijk.

EHRM 20 maart 1991, nr. 15576/89, Cruz Varas e.a./Zweden.

EHRM 30 oktober 1991, nrs. 13163/87, 13164/87, 13165/87, 13447/87, 13448/87, Vilvarajah e.a./Verenigd Koninkrijk.

EHRM 25 juni 1996, nr. 19776/92, Amuur/Frankrijk.

EHRM 11 november 1996, nr. 17862/91, Cantoni/Frankrijk.

EHRM 15 november 1996, nr. 22414/93, Chahal/Verenigd Koninkrijk.

EHRM 17 december 1996, nr. 25964, Ahmed/Oostenrijk.

EHRM 29 april 1997, nr. 24573/94, H.L.R./Frankrijk. 
EHRM 2 mei 1997, nr. 146/1996/767/964, D./Verenigd Koninkrijk.

EHRM 25 mei 1998, nr. 15/1997/799/1002, Kurt/Turkije.

EHRM 18 februari 1999, nr. 24833/94, Matthews/Verenigd Koninkrijk.

EHRM 11 juli 2000, nr. 40035/98, Jabari/Turkije.

EHRM 16 mei 2002, nr. 39474/98, D.G./Ierland.

EHRM 18 juni 2002, nr. 25656/94, Orhan/Turkije.

EHRM 30 juni 2005, nr. 45036/98, Bosphorus Hava Yollari Turizm Ve Ticaret Anonim Sirketi (Bosphorus Airways)/Ierland.

EHRM 12 oktober 2006, nr. 13178/o3, Mubilanzila Mayeka en Kaniki Mitunga/België.

EHRM 11 oktober 2007, nr. 656/o6, Nasrulloyev/Rusland.

EHRM 24 januari 2008, nrs. 29787/03 en 29810/03, Riad en Idiab/België.

EHRM 28 februari 2008, nr. 37201/o6, Saadi/Italië.

EHRM 23 juni 2008, nr. 1638/o3, Maslov/Oostenrijk.

EHRM 22 september 2009, nr. 30471/o8, Abdolkhani en Karimnia/Turkije.

EHRM 19 januari 2010, nr. 41442/o7, Muskhadzhiyeva en anderen /België.

EHRM 1 juni 2010, nr. 22978/o5, Gäfgen/Duitsland.

EHRM 28 oktober 2010, nr. 41533/o8, Bubullima/Griekenland.

EHRM 21 januari 2011, nr. 30696/o9, M.S.S./België en Griekenland.

EHRM 5 april 2011, nr. 8687/o8, Rahimi/Griekenland.

EHRM 19 april 2012, nr. 39472/o7, Popov/Frankrijk.

EHRM 8 november 2012, nr. 28973/11, Z.H./Hongarije.

EHRM 23 juli 2013, nr. 41872/10, M.A./Cyprus.

EHRM 24 oktober 2013, nr. 71825/11, Housein/Griekenland.

EHRM 4 november 2014, nr. 29217/12, Tarakhel/Zwitserland.

EHRM 11 december 2014, nr. 70586/11, Mohamad/Griekenland.

EHRM 2 april 2015, nr. 39766/o9, Aarabi/Griekenland.

EHRM 24 maart 2016, nr. 14165/16, Sh.D. en anderen/Griekenland.

EHRM 24 maart 2016, nr. 28026/o5, Sharma/Letland.

EHRM 12 juli 2016, nr. 11593/12, A.B. e.a. /Frankrijk.

EHRM 12 juli 2016, nr. 33201/11, R.M. e.a. /Frankrijk.

EHRM 12 juli 2016, nr. 68264/14, R.K. e.a./Frankrijk.

EHRM 12 juli 2016, nr. 76491/14, R.C. en V.C./Frankrijk.

EHRM 22 november 2016, nrs. 25794/13 en 28151/13, Abdullahi Elmi en Aweys Abubakar/Malta.

EHRM 15 december 2016, nr. 16483/12, Khlaifia e.a./Italië.

EHRM 5 juli 2017, nr. 9912/15, O.M./Hongarije.

\section{§2. Hof van Justitie van de Europese Unie}

HvJ 5 februari 1963, C-26/62, ECLI:EU:C:1963:1, Van Gend \& Loos.

HvJ 17 mei 1972, C-93/71, ECLI:EU:C:1972:39, Leonesio.

HvJ 5 april 1979, C-148/78, ECLI:EU:C:1979:110, Ratti.

HvJ 2 maart 2010, C-175/o8, C-176/o8, C-178/o8 en C-179/o8, ECLI:EU:C:2010:105, Abdulla, Hasan, Adem, Rashi en Jama/Duitsland. 
HvJ 21 december 2011, C-411/10, ECLI:EU:C:2011:865, N.S./Secretary of State for the Home Department e.a.

HvJ 26 februari 2013, C-617/10, ECLI:EU:C:2013:105, Aklagaren/Hans Åkerberg Fransson.

HvJ 6 juni 2013, C-648/11, ECLI:EU:C:2013:367, M.A. e.a./Secretary of State for the Home Department.

HvJ 10 juli 2014, C-198/13, ECLI:EU:C:2014:2055, Julian Hernandez en anderen.

HvJ 18 december 2014, Advies 2/13, ECLI:EU:C:2014:2454, Advies krachtens artikel 218 lid 11 VWEU (Toetreding EU tot het EVRM).

HvJ 16 februari 2017, C-578/16, ECLI:EU:C:2017:127, C.K. e.a./Republika Slovenija.

HvJ 28 februari 2017, T-192/16, ECLI:EU:T:2017:128, N.F./Europese Raad.

HvJ 9 maart 2017, C-406/15, ECLI:EU:C:2017:198, Milkova.

\section{§3. Andere}

Belgisch Hof van Cassatie 4 november 1999, C.99.0111.N, Van Hauwermeiren/Van Damme e.a.

Belgisch Hof van Cassatie 26 mei 2008, S.06.0105.F, D.D., A.S/H.D.P. Caisse de Compensation pour allocations familiales.

Belgisch Hof van Cassatie 11 juni 2010, C.09.0236.F, W.N./D. M.-J.

Belgische Raad van State 30 maart 2005, 142.729.

Belgische Raad van State 29 mei 2013, 223.630.

Franse Cour de Cassation 1 oktober 2005, 1810, X/Y.

Italiaans Grondwettelijk Hof 24 oktober 2007, 348.

Nederlandse Centrale Raad van Beroep 24 januari 2006, 05/3621.

Nederlandse Raad van State 22 februari 2006, 200507814/1.

\section{Afdeling III. Rechtsleer}

\section{§1. Boeken}

Alston, P. en Goodman, R., International Human Rights, Oxford: Oxford University Press 2013, 1580.

Boeles, P., Den Heijer, M., Lodder, G. en Wouters, K., European Migration Law, Antwerpen: Intersentia 2014 , 455.

Buck, T., International Child Law, Londen: Routledge 2014, 478.

Cardol, G., Ontheemd, vreemd en minderjarig - Het recht op ontwikkeling van de alleenstaande minderjarige vreemdeling in (inter)nationale wet- en regelgeving, Nijmegen: Wolf Legal Publishers 2005, 497.

Carlier, J.Y. en Sarolea, S., Droit des étrangers, Brussel: Larcier 2016, 831.

Cherubini, F., Asylum Law in the European Union, Londen: Routledge 2015, 290.

Clayton, R. en Tomlinson, H., The Law of Human Rights, Oxford: Oxford University Press 2009, 2193.

Costello, C., The Human Rights of Migrants and Refugees in European Law, Oxford: Oxford University Press $2016,356$.

Denys, L., Overzicht van het vreemdelingenrecht, Heule: Inni Publishers 2019, 1153.

Hailbronner, K. en Thym, D., EU Immigration and asylum law- a commentary, München: C.H. Beck $2016,1638$.

Harris, D., O’Boyle, M., Bates, E. en Buckley, C., Law of the European Convention on Human Rights, Oxford: Oxford University Press 2014, 1006.

Leboeuf, L., Le droit européen de l'asile - Au défi de la confiance mutuelle, Limal: Anthemis $2016,470$.

Liefaard, T., Deprivation of Liberty of Children in Light of International Human Rights Law and Standards, Antwerpen: Intersentia 2008, 696.

Mole, N. en Meredith, C., Asylum and the European Convention on Human Rights, Straatsburg, Council of Europe Publishing, $2010,283$.

Peers, S., Moreno-Lax, V., Garlick, M. en Guild, E., EU Immigration and Asylum Law (Text and Commentary): Second Revised Edition, Leiden: Brill Nijhoff 2015, 673 .

Put, J., Handboek Jeugdbeschermingsrecht, Brugge: Die Keure 2015, 589. 
Rainey, B., Wicks, E. en Ovey, C., The European Convention on Human Rights, Oxford: Oxford University Press $2017,692$.

Sarolea, S., Droits de l'homme et migrations: de la protection au migrant aux droits de la personne migrante, Brussel: Bruylant 2006, 718 .

Schabas, W.A., The European Convention on Human Rights, Oxford: Oxford University Press 2015, 1308.

Velluti, S., Reforming the Common European Asylum System- legislative developments and judicial activism of the European courts, Londen: Springer Heidelberg 2014, 109.

Wouters, J., Ryngaert, C., Ruys, T. en De Baere, G., International Law - A European Perspective, Oxford: Hart $2019,1038$.

\section{§2. Verzamelwerken}

Ando, N., 'General Comments/Recommendations', in encyclopedie, Oxford Public International Law, Oxford: Oxford University Press 2008.

Bauloz, C., Ineli-Ciger, M., Singer, S. en Stoyanova, V., 'Introducing the Second Phase of the Common European Asylum System', in Bauloz, C., Ineli-Ciger, M., Singer, S. en Stoyanova, V. (red.), Seeking Asylum in the European Union, Leiden: Brill Nijhoff 2015, 297.

Biondi, P., 'Compliance with Fundamental Rights Demands Shared Responsibility', in V. Stoyanova en E. Karageorgiou (red.), The New Asylum and Transit Countries in Europe during and in the Aftermath of the 2015/2016 Crisis, Leiden: Brill Nijhoff 2019, 307.

Blaak, M., Bruning, M., Eijgenraam, M., Kaandorp, M. en Meuwese, S., 'De Rechten van het Kind', in M. Blaak, M. Bruning, M. Eijgenraam, M. Kaandorp en S. Meuwese (red.), Handboek Internationaal Jeugdrecht, Leiden: Defence for Children $2012,166$.

Bleichrodt, E., 'Right to Liberty and Security', in P. van Dijk, F. van Hoof, A. van Rijn en L. Zwaak (red.), Theory and Practice of the European Convention on Human Rights, Antwerpen: Intersentia 2018, 1230.

Bossuyt, M., 'De inroepbaarheid van verdragsbepalingen of wat is er rechtstreeks aan de rechtstreekse werking?', in J. Wouters en D. Van Eeckhoutte (red.), Doorwerking van internationaal recht in de Belgische rechtsorde, Antwerpen: Intersentia $2006,652$.

Bossuyt, M., 'Is the European Court of Human Rights on a slippery slope?', in S. Flogaitis, T. Zwart en J. Fraser (red.), The European Court of Human Rights and its discontents: turning criticism into strength, Cheltenham, Edward Elgar, $2013,240$.

Brandl, U. en Czech, P., 'General and Specific Vulnerability of Protection-Seekers in the EU: Is there an Adequate Response to their Needs?', in F. IPPOLITO en S. IGLESIAS (red.), Protecting Vulnerable Groups: The European Human Rights Framework, Oxford: Hart Publishing 2015, 494.

Cambien, N. en Van Nieuwenborgh, M., 'De EU-rechtsorde: de beginselen van voorrang en rechtstreekse werking', in J. Nowak en N. Cariat (red.), Le droit de l'Union européenne et le juge belge / Het recht van de Europese Unie en de Belgische rechter, Brussel: Larcier 2015, 504.

Chomsky, A., 'A central American drama in four facts', in M. Lopez-Stafford Levy (red.), Children from the other America, Rotterdam: Sense Publishers 2016, 116.

Farrugia, R. en Touzenis, K. 'The international protection of unaccompanied and separated migrant and asylum-seeking children in Europe', in J. Kanics, D.S. Hernandez en K. Touzenis (red.), Migrating alone- Unaccompanied and separated children's migration to Europe, Unesco Publishing, 2010, 187.

Fournier, K., 'De voogdijwet voor niet-begeleide minderjarige vreemdelingen: terug- en vooruitblik', in D. Vanheule (red.), Migratie en migrantenrecht - ontwikkelingen inzake arbeidsdiscriminatie, detachering van werknemers, kinderontvoering en de Dublinverordening, Brugge: Die Keure 2017, 207.

Limbeek, M. en Bruning, M., 'The Netherlands - Two Decades of the CRC in Dutch Case Law', in T. Liefaard en J.E. Doek (red.), Litigating the Rights of the Child, Dordrecht, Springer, 2014, 265.

Maes, A., 'Asielrecht in de kering: de nieuwe Dublinverordening en de nieuwe kwalificatierichtlijn', in D. Vanheule (red.), Migratie en migrantenrecht - ontwikkelingen inzake arbeidsdiscriminatie, detachering van werknemers, kinderontvoering en de Dublinverordening, Brugge: Die Keure 2017, 207.

Matera, C., 'The Influence of International Organisations on the EU's Area of Freedom, Security and Justice: A First Inquiry', in R.A. Wessel en S. Blockmans (red.), Between Autonomy and Dependence, Den Haag: Springer 2014, 340.

Pollet, K., ‘Grondrechtenbescherming in de Dublin III-verordening: de doodsteek voor het Dublinsysteem?’, in D. Vanheule (red.), Migratie en migrantenrecht - ontwikkelingen inzake arbeidsdiscriminatie, detachering van werknemers, kinderontvoering en de Dublinverordening, Brugge: Die Keure 2017, 207.

Vandenhole, W., 'Belgium - The Convention of the Rights of the Child in Belgian Case Law', in T. Liefaard en J.E. Doek (red.), Litigating the Rights of the Child, Dordrecht, Springer, 2014, 265.

Vandenhole, W., 'Children's rights from a legal perspective: Children’s rights law', in W. Vandenhole, E. Desmet, D. Reynaert en S. Lembrechts (red.), Routledge International Handbook of Children's Rights Studies, Londen: Routledge 2015, 436.

Vermeulen, B. en Battjes, H., 'Prohibition of Torture and Other Inhuman or Degrading Treatment or Punishment', in P. van Dijk, F. van Hoof, A. van Rijn en L. Zwaak (red.), Theory and Practice of the European Convention on Human Rights, Antwerpen: 
Intersentia 2018, 1230.

Woltjer, A., 'The European Court of Human Rights and the Court of Justice of the European Union: an Imperfect Match? Interaction Between both Courts in the Field of Immigration Law', in M. van Roosmalen, B. Vermeulen, F. van Hoof en M. Oosting (red.), Fundamental Rights and Principles: Liber Amicorum Pieter van Dijk, Antwerpen: Intersentia $2013,584$.

\section{§3. Tijdschriften}

Allsopp, J. en Chase, E., 'Best Interests, Durable Solutions and Belonging: Policy Discourses Shaping the Futures of Unaccompanied Migrant and Refugee Minors Coming of Age in Europe', Journal of Ethnic and Migration Studies 45(2), 2019, 293-311.

Androff, D., 'The Human Rights of Unaccompanied Minors in the USA from Central America', Journal of Human Rights and Social Work 1(2), 2016, 71-77.

Ataiants, J., Cohen, C., Henderson Riley, A., Tellez Lieberman, J., Reidy, M.C. en Chilton, M., 'Unaccompanied Children at the United States Border, a Human Rights Crisis that can be Addressed with Policy Change', Journal Immigrant Minority Health 20(4), 2018, 1000-1010.

Battjes, H., Dembour, M.-B., 't Hart, B. en Farahat, A., 'Introduction: the European Court of Human Rights and immigration: limits and possibilities', European Journal of Migration and Law 11, 2009, 199-204.

Beduschi, A., 'Vulnerability on Trial: Protection of Migrant Children's Rights in the Jurisprudence of International Human Rights Courts', Boston University International Law Journal 36(1), 2018, 55-85.

Bhabha, J., 'Arendt's children: do today's migrant children have a right to have rights?', Human Rights Quarterly 31, 2009, 410451.

Bossuyt, M., 'The European Union Confronted with an Asylum Crisis in the Mediterranean: Reflections on Refugees and Human Rights Issues', European Journal of Human Rights 5, 2015, 581-605.

Brekke, J.-P., 'Stuck in transit: secondary migration of asylum seekers in Europe, national differences and the Dublin Regulation', Journal of Refugee Studies 28(2), 2014, 145-162.

Bruin, R., Kok, S.G. en Terlouw, A., 'Dublin: blind interstatelijk vertrouwen is een fictie: over inwilligingspercentages en overdrachten', Justitiële Verkenningen 41(3), 2015, 71-89.

Byrne, K., 'Migrant, Refugee or Minor? It Matters for Children in Europe', FMReview, 2017, 94-96.

Casarico, A., Facchini, G. en Testa, C., 'Asylum policy and illegal immigration: perspectives and challenges', DICE report 14(4), 2016, 14-20.

Comte, F., 'A New Agency is Born in the European Union: the European Asylum Support Office', European Journal of Migration and Law 1(4), 2010, 373-405.

Cornelisse, G., 'Mensenrechten begrensd: detentie in het vreemdelingenrecht', Justitiële Verkeningen 38(6), 2012, 52-66.

De Graeve, K., 'Classed Landscapes of Care and Belonging: Guardianships of Unaccompanied Minors', Journal of Refugee Studies 30(1), 2015, 71-88.

Den Heijer, M., Rijpma, J. en Spijkerboer, T., 'Coercion, Prohibiton and Great Expectations: The Continuing Failure of the Common European Asylum System', Common Market Law Review 52, 2016, 607-642.

Devi, S. ‘Unaccompanied Migrant Children at Risk across Europe’, World Report 387, 2016, 2590.

Etinski, R. en Dajic, S., 'Direct Effect of the European Convention on Human Rights', Belgrade Law review LXIII(3), 2015, 91111.

Fleuren, J., 'De historische ontwikkeling van de verhouding tussen internationaal recht en nationaal recht', Ars Aequi 61, 2012, 510-519.

Gimeno-Monterde, C. en Guttierez-Sanchez, J.D., 'Fostering Unaccompanied Migrating Minors: A Cross-border Comparison', Children and Youth Services Review 99, 2019, 36-42.

Gjipali, D., 'The External Dimension of EU Migration Policy', Academicus: International Scientific Journal MMXVII(15), 2017, 158-165.

Greenman, K., 'A Castle Built on Sand? Article 3 ECHR and the Source of Risk in Non-Refoulement Obligations in International Law', International Journal of Refugee Law 27(2), 2015, 264-296.

Hernandez, D.S., 'Analyse d'une catégorie juridique récente: le mineur étranger non accompagné, séparé ou isolé', Revue européenne des migrations 30, 2014, 17-34.

Kalverboer, M., Beltman, D., Van Os, C. en Zijlstra, E., 'The Best Interests of the Child in Cases of Migration: Assessing and Determining the Best Interests of the Child in Migration', International Journal of Children's Rights 25, 2017, 114-139.

Kenny, M.A. en Loughry, A., 'Addressing the limitations of age determination for unaccompanied minors: A way forward', Children and Youth Services Review 92, 2018, 15-21. 
Koffeman, N.R. en Hillary, L., 'Mensenrechtelijke zorgen bij de planning voor herziening van het gemeenschappelijk Europees asielsysteem', NTM 43(1), 2018, 113-132.

Kok, S., 'Hoe functioneert het Dublinsysteem? Over de weerbarstige praktijk', A\&MR 6(7), 2016, 291-297.

Lavrysen, L., 'Positive Obligations in the Jurisprudence of the Inter-American Court of Human Rights', Inter-American and European Human Rights Journal 1(2), 2014, 94-115.

Lenart, J., 'Fortress Europe': compliance of the Dublin II regulation with the European Convention for the Protection of Human Rights and Fundamental Freedoms', Utrecht Journal of International and European Law 28(75), 2012, 4-19.

Menjivar, C. en Perreira, K.M., 'Undocumented and Unaccompanied: Children of Migration in the European Union and the United States', Journal of Ethnic and Migration Studies, 2017, 1-21.

Moreno-Lax, V., 'Dismantling the Dublin System: M.S.S. v. Belgium and Greece', European Journal of Migration and Law 14, 2012, 1-31.

Nguema, N.E. 'La protection des mineurs migrants non-accompagnés en Europe', Revue du Centre de recherches et d'études sur les droits fondamentaux 7, 2015, 1-21.

Nicolosi, S.F., 'Going unnoticed? Diagnosing the right to asylum in the Charter of Fundamental Rights of the European Union', European Law Journal 23 (1-2), 2017, 94-117.

O’Donnell, R. en Kanics, J., 'Separated and Unaccompanied Children in the EU’, Forced Migration Review 51, 2016, 73-75.

Parusel, B., 'Unaccompanied Minors in the European Union - Definitions, Trends and Policy Overview', Social Work and Society International Online Journal 15, 2017, 1-15.

Peers, S., 'The Second Phase of the Common European Asylum System: A Brave New World - or Lipstick on a Pig?', Statewatch Analysis, 2013, 1-17.

Reneman, M., 'Het Kinderrechtenverdrag krijgt tanden', A\&MR 8, 2011, 349-362.

Reneman, M., 'Implementatie van de herziene Asielprocedurerichtlijn: een nieuwe beslissystematiek en meer waarborgen voor asielzoekers', Nederlands Tijdschrift voor Europees Recht 2015(8), 2015, 250-256.

Roots, L., 'The New EURODAC Regulation: Fingerprints as a Source of Informal Discrimination', Baltic Journal of European Studies 5(2), 2015, 108-129.

Ruet, C., 'La vulnérabilité dans la jurisprudence de la Cour européenne des droits de l'homme', Revue trimestrielle des droits de l'homme 102, 2015, 317-339.

Smyth, C., 'Is the right of the child to liberty safeguarded in the Common European Asylum System?', European Journal of Migration and Law 15, 2013, 111-136.

Strik, T. 'De externe dimensie van het EU migratiebeleid: uit het oog of uit het recht?', NTM 43(1), 2018, 64-86.

Valtolina, G.G. en D’Odorico, M., 'Crossing Alone the Mediterranean Sea, Some Critical Issues About Unaccompanied Minors in Europe', Revista Interdisciplinar da Mobilidade Humana 25, 2017, 77-94.

Van Os, C., 'De relevantie van het Kinderrechtenverdrag voor minderjarige vreemdelingen', Justitiële Verkenningen 38(6), 2012, 67-82.

Vandenhole, W., 'Editoriaal - Kinderrechten op het scherpst van de snede’, TJK (1), 2016, 3-5.

Vanheule, D., 'Het Global Compact for Safe, Orderly and Regular Migration', $R W$ 82(25), 2019, 962.

Verhaegen, B., 'De Wettelijke Vertegenwoordiging van Niet-begeleide Minderjarige Vreemdelingen', Jura Falconis 40(4), 2004, 873-906.

\section{Afdeling IV. Media}

Achilli, L., 'Why are we not reforming the Dublin Regulation yet?', Euractiv, 25 oktober 2018,

https://www.euractiv.com/section/justice-home-affairs/opinion/why-are-we-not-reforming-the-dublin-regulation-yet/.

Agentschap Integratie en Inburgering, 'RvV bevestigt mogelijkheid tot Dublinoverdracht naar Griekenland onder bepaalde voorwaarden', Agentschap Integratie en Inburgering, 4 juli 2018, http://www.agii.be/nieuws/rvv-bevestigt-mogelijkheid-totdublinoverdracht-naar-griekenland-onder-bepaalde-voorwaarden.

Amnesty International, 'Waarom een humaan asielbeleid wel mogelijk is', Amnesty International, 28 juni 2018, https://www.amnesty-international.be/nieuws/waarom-een-humaan-asielbeleid-wel-mogelijk-is.

Baert, D., '9-Jarig Palestijns jongetje dood gevonden in asielcentrum van Broechem, vijf verdachten opgepakt', VRT NWS, 24 april 2019, https://www.vrt.be/vrtnws/nl/2019/04/24/jongetje-dood-gevonden-in-asielcentrum-in-broechem-vijf-asielz/.

Balliauw, J., 'Migratie doet de EU op haar grondvesten daveren', VRT NWS, 9 december 2018,

https://www.vrt.be/vrtnws/nl/2018/12/o7/migratie-doet-de-eu-op-zijn-grondvesten-daveren/. 
Brzozowski, A., 'No agreement on asylum possible before EU elections, EU member states admit', Euractiv, 8 maart 2019, https://www.euractiv.com/section/justice-home-affairs/news/no-agreement-on-asylum-possible-before-eu-elections-eumember-states-admit/.

Collins, L., 'Europe's Child Refugee Crisis', The New Yorker, 27 februari 2017,

https://www.newyorker.com/magazine/2017/02/27/europes-child-refugee-crisis.

De Telegraaf, 'Vluchtelingenwerk: Opvangcentra raken vol', De Telegraaf, 2 november 2018,

https://www.telegraaf.nl/nieuws/2752905/vluchtelingen-werk-opvangcentra-raken-vol.

De Vroey, B., 'Twee jaar EU-Turkije-akkoord: een bedenkelijk succes', VRT NWS, 16 maart 2018, https://www.vrt.be/vrtnws/nl/2018/03/16/bedenkelijk-succes-/.

Europees Parlement persmededeling, 'Reception conditions for asylum-seekers agreed between MEPs and Council', europa.eu, 14 juni 2018, http://www.europarl.europa.eu/news/en/press-room/20180614IPR05803/reception-conditions-for-asylum-seekersagreed-between-meps-and-council.

Europese Commissie persmededeling, 'Towards a Sustainable and Fair Common European Asylum System', europa.eu, 4 mei 2016, http://europa.eu/rapid/press-release_IP-16-1620_en.htm.

Europese Raad persmededeling, ‘European Council Conclusions, 28 june 2018', consilium.europa.eu, 29 juni 2018, https://www.consilium.europa.eu/en/press/press-releases/2018/o6/29/20180628-euco-conclusions-final/pdf.

Europese Raad persmededeling, 'Verklaring EU-Turkije', consilium.europa.eu, 18 maart 2016, https://www.consilium.europa.eu/nl/press/press-releases/2016/03/18/eu-turkey-statement/.

Eurostat news release, '63.300 Unaccompanied Minors Among Asylum Seekers Registered in the EU in 2016: over Half are Afghans or Syrians', europeanmigrationlaw.eu, 11 mei 2017,

http://www.europeanmigrationlaw.eu/documents/Asylum\%20applicants\%20considered\%20to\%2obe\%20unaccompanied\%2ominors.pdf.

eurostat news release, 'Over 31.0oo Unaccompanied Minors Among Asylum Seekers Registered in the EU in 2017', ec.europa.eu, 16 mei 2018, https://ec.europa.eu/eurostat/documents/2995521/8895109/3-16052018-BP-EN.pdf/ec4cc3d7-c177-4944-964fd85401e55ad9.

Eurostat news release, 'Almost 20.00o Unaccompanied Minors Among Asylum Seekers Registered in the EU in 2018', ec.europa.eu, 26 april 2019, https://ec.europa.eu/eurostat/documents/2995521/9751525/3-26042019-BP-EN.pdf/291c8e8745b5-4108-920d-7d702c1d6990.

Gladstone, R., '300,00o Child Refugees and Migrants Traveled Alone in '15 and '16, U.N. Says', The New York Times, 17 mei 2017, https://www.nytimes.com/2017/05/17/world/americas/united-nations-children-refugees-migrants-trafficking.html.

Gotev, G., 'Nine EU members stay away from UN Migration Pact', Euractiv, 20 december 2018,

https://www.euractiv.com/section/global-europe/news/nine-eu-members-stay-away-from-un-migration-pact/.

Knack, 'Plannen opsluiten migrantengezinnen: Francken verdedigt zich tegen Raad van Europa', Knack, 14 juni 2018, https://www.knack.be/nieuws/belgie/plannen-opsluiten-migrantengezinnen-francken-verdedigt-zich-tegen-raad-vaneuropa/article-normal-1160871.html.

Laessing, U. en Rinke, A., 'More than 160 countries sign UN migration pact; U.S. and others opt out', The Globe and Mail, 10 december 2018, https://www.theglobeandmail.com/world/article-more-than-16o-countries-sign-un-migration-pact-us-andothers-reject/.

Liga voor de Mensenrechten, 'The Stockholm Program', Liga voor de Mensenrechten, 29 oktober 2009, https://mensenrechten.be/nieuwsberichten/the_stockholm_program.

Oxfam, 'You aren't human any more', Migrants expose the harrowing situation in Libya and the impact of European policies', Oxfam media briefing, 9 augustus 2017, https://www.oxfam.org/en/research/you-arent-human-any-more-migrants-exposeharrowing-situation-libya-and-impact-eu.

Pollet, K., 'All in vain? The fate of EP positions on asylum reform after the European elections', EU Immigration and Asylum Law and Policy Blog, 23 mei 2019, http://eumigrationlawblog.eu/all-in-vain-the-faith-of-ep-positions-on-asylum-reform-afterthe-european-elections/.

Struys, B., 'Opvangcentra zitten overvol door grotere instroom: tenten voor azielzoekers weer in beeld', De Morgen, 16 november 2018, https://www.demorgen.be/nieuws/opvangcentra-zitten-overvol-door-grotere-instroom-tenten-voor-asielzoekers-weer-inbeeld-b14afd39/.

Vanrenterghem, A., 'Aantal niet-begeleide minderjarige vreemdelingen dat verdween lag nog nooit zo hoog', VRT NWS, 30 april 2019, https://www.vrt.be/vrtnws/nl/2019/04/30/nooit-verdwenen-meer-niet-begeleide-minderjarige-vreemdelingen-i/.

Van Stichel, W., 'Vermiste dieren krijgen meer aandacht dan minderjarige vluchtelingen', De Standaard, 23 april 2018, http://www.standaard.be/cnt/dmf20180423_03478488.

Vercruysse, S., 'Wat staat er in het migratiepact en waarom keurt de regering het nog niet goed?', VRT NWS, 17 november 2018, https://www.vrt.be/vrtnws/nl/2018/11/17/n-va-blijft-belgische-steun-aan-vn-migratiepact-tegenhouden/.

Vidal, E., 'Details of EU Agreement on Migration', Reuters, 29 juni 2018, https://www.reuters.com/article/us-eu-summitconclusions-migration/details-of-eu-agreement-on-migration-idUSKBN1JPoDS. 


\section{Afdeling V. Miscellania}

AIDA Country Report Belgium: 2018 update, maart 2019.

AIDA Country Report France: 2018 update, maart 2019.

AIDA Country Report Greece: 2018 update, maart 2019.

AIDA Country Report Ireland: 2018 update, februari 2019.

AIDA Country Report Italy: 2017 update, maart 2018.

AIDA Country Report Netherlands: 2018 update, maart 2019.

AIDA Country Report Poland: 2018 update, maart 2019.

AIDA Country Report Portugal: 2017 update, maart 2018.

ECRE, Comments on the Commission Proposal for a Dublin IV Regulation (Com(2016) 270), oktober 2016.

ECRE, Comments on the Commission Proposal to recast the Reception Conditions Directive (Com (2016) 465), oktober 2016.

Europees Parlement, Briefing: Reform of the Dublin System, 1 maart 2019,

http://www.europarl.europa.eu/RegData/etudes/BRIE/2016/586639/EPRS_BRI\%282016\%29586639_EN.pdf.

FRA, Opinion of the European Union Agency for Fundamental Rights on the impact of the proposal for a revised Dublin Regulation (COM(2016)270 final; 2016/o133 COD), 23 november 2016.

Kestemont, L., 'Methods for traditional legal research', Reader 'Methods of Legal Research', Research Master in Law, KU Leuven

- University of Tilburg, 2014-2015.

Kestemont, L. en Schoukens, P., Rechtswetenschappelijk schrijven, Leuven: Acco 2012, 135.

MYRIA, Europa in (asiel)crisis, Myriadocs, juni 2016, https://www.myria.be/files/Myriadocs-1-NL-Europaincrisis.pdf.

MYRIA, Migratie in cijfers en in rechten 2015, Myriadocs, 3 september 2015, https://www.myria.be/nl/publicaties/migratie-incijfers-en-in-rechten-2015.

Position Paper of Cyprus, Greece, Italy, Malta and Spain on the Proposal recasting the Dublin Regulation, 4 mei 2018, https://g8fip1kplyr33r3krz5b97d1-wpengine.netdna-ssl.com/wp-content/uploads/2018/o4/Position-paper-Dublin.pdf.

The African Child Policy Forum, Definition of the Child: The International/regional Legal Framework, 2013, http://www.youthpolicy.org/wp-content/uploads/library/2013_Africa_Child_Law_Comparison_Eng.pdf.

Tijssen, H., De juridische dissertatie onder de loep, Den Haag: Boom juridische uitgevers 2009, 233.

Vluchtelingenwerk Vlaanderen, Wat is Dublin?, 19 oktober 2013, https://www.vluchtelingenwerk.be/sites/default/files/wat-isdublin_v04-201602-distribution.pdf.

Written Submissions on Behalf of the AIRE, the ECRE and the ICJ to the case Sh.D. and others/Greece and others, 12 augustus 2016, 10 p.,

http://www.asylumlawdatabase.eu/sites/www.asylumlawdatabase.eu/files/aldfiles/Sh.\%20D.\%20and\%20others\%20v.\%20Greece\%20and\%20 \%20TPI.pdf.

Bijlage: Overzicht van wetgeving en voorstellen (in volgorde van voorkomen in het werk)

\begin{tabular}{|c|c|c|}
\hline Huidige wetgeving & Voorstel Commissie & Voorstel Parlement \\
\hline $\begin{array}{l}\text { Artikel } 3 \text { lid } 2 \text { (2) Dublin III } \\
\text { Indien het niet mogelijk is een verzoeker over te } \\
\text { dragen aan de lidstaat die in de eerste plaats als } \\
\text { verantwoordelijke lidstaat is aangewezen, omdat } \\
\text { ernstig moet worden gevreesd dat de } \\
\text { asielprocedure en de opvangvoorzieningen voor } \\
\text { verzoekers in die lidstaat systeemfouten bevatten } \\
\text { die resulteren in onmenselijke of vernederende } \\
\text { behandelingen in de zin van artikel } 4 \text { van het } \\
\text { Handvest van de grondrechten van de Europese } \\
\text { Unie, blijft de lidstaat die met het bepalen van de } \\
\text { verantwoordelijke lidstaat is belast de criteria van } \\
\text { hoofdstuk III onderzoeken teneinde vast te stellen } \\
\text { of een andere lidstaat als verantwoordelijke } \\
\text { lidstaat kan worden aangewezen. }\end{array}$ & $\begin{array}{l}\text { Artikel } 3 \text { lid } 2 \text { (2) } \\
\text { Dublin IV } \\
\text { Idem huidige wetgeving. }\end{array}$ & $\begin{array}{l}\text { Artikel } 3 \text { lid } 2 \text { (2) Dublin IV } \\
\text { Indien het niet mogelijk is een verzoeker } \\
\text { over te dragen aan de lidstaat die in de } \\
\text { eerste plaats als verantwoordelijke } \\
\text { lidstaat is aangewezen, omdat ernstig } \\
\text { moet worden gevreesd dat er een reëel } \\
\text { risico bestaat dat de grondrechten van de } \\
\text { verzoeker zwaar zullen worden } \\
\text { geschonden, blijft de lidstaat die met het } \\
\text { bepalen van de verantwoordelijke lidstaat } \\
\text { is belast de criteria van hoofdstuk III } \\
\text { onderzoeken teneinde vast te stellen of } \\
\text { een andere lidstaat als verantwoordelijke } \\
\text { lidstaat kan worden aangewezen. }\end{array}$ \\
\hline
\end{tabular}




\section{Artikel 8 lid 4 Dublin III}

Bij ontstentenis van gezinsleden, broers of zussen of familieleden als vermeld in de leden 1 en 2 is de lidstaat waarbij de niet-begeleide minderjarige zijn verzoek om internationale bescherming heeft ingediend de verantwoordelijke lidstaat, mits dit in het belang is van de minderjarige.

\section{Artikel 10 lid 5}

Dublin IV

Bij ontstentenis van gezinsleden of familieleden als vermeld in de leden 2 en 3 , is de lidstaat waarbij de nietbegeleide minderjarige zijn verzoek om internationale bescherming het eerst heeft ingediend de verantwoordelijke lidstaat, tenzij wordt aangetoond dat dit niet in het belang van de minderjarige is.

\section{Artikel 10 lid 5 Dublin IV}

Bij ontstentenis van gezinsleden of familieleden als vermeld in de leden 2 en 3 , en indien er geen andere criteria als bedoeld in de hoofdstukken III en IV, met name in artikel 19, van toepassing zijn, wordt de verantwoordelijke lidstaat bepaald aan de hand van het in hoofdstuk VII bedoelde toewijzingsmechanisme, op voorwaarde dat de minderjarige altijd de keuze krijgt tussen de lidstaten van toewijzing overeenkomstig artikel 36 lid 1 quater. Elke beslissing over de verantwoordelijke lidstaat moet worden voorafgegaan door een multidisciplinaire beoordeling van het belang van de minderjarige, ook in het geval van toewijzing.

\section{Artikel 6 lid 2 (eerste zin) Dublin III}

De lidstaten zorgen ervoor dat de niet-begeleide minderjarige bij alle procedures waarin deze verordening voorziet, wordt vertegenwoordigd en/of bijgestaan door een vertegen woordiger.

\section{Artikel 8 lid 2 (eerste zin) Dublin IV}

Elke lidstaat zorgt ervoor dat, wanneer een nietbegeleide minderjarige aanwezig moet zijn, de niet-begeleide minderjarige bij de relevante procedures waarin deze verordening voorziet, wordt vertegenwoordigd en/of bijgestaan door een vertegenwoordiger.

\section{Artikel 9 lid 3 en 4 Opvangrichtlijn}

3. Wanneer de bewaring wordt bevolen door een administratieve instantie, zorgen de lidstaten er ambtshalve of op verzoek van de verzoeker voor dat de rechtmatigheid van de bewaring door de rechter met spoed wordt getoetst. Indien de rechtmatigheid van de bewaring ambtshalve wordt getoetst, wordt het besluit daartoe zo spoedig mogelijk bij aanvang van de bewaring genomen. Indien de verzoeker om toetsing verzoekt, wordt het besluit tot toetsing van de rechtmatigheid zo spoedig mogelijk na de aanvang van de betrokken procedures genomen. Te dien einde stellen de lidstaten in hun nationale recht een termijn vast binnen welke de rechterlijke toetsing ambtshalve en/of de rechterlijke toetsing op verzoek van de verzoeker moet worden uitgevoerd.

Indien de toetsing ertoe leidt dat de bewaring als niet rechtmatig beoordeeld wordt, wordt de betrokken verzoeker onmiddellijk vrijgelaten.

4. Verzoekers die in bewaring worden gehouden, worden onmiddellijk schriftelijk, in een taal die zij verstaan of waarvan redelijkerwijs kan worden aangenomen dat zij deze verstaan, op de hoogte gebracht van de redenen van bewaring en van de in het nationale recht vastgestelde procedures om het bevel tot bewaring aan te vechten, alsook van de mogelijkheid om gratis rechtsbijstand en vertegenwoordiging aan te vragen.

\section{Artikel 8 lid 2 (eerste zin) Dublin IV}

Elke lidstaat zorgt ervoor dat, wanneer er een niet-begeleide minderjarige aanwezig is, de niet-begeleide minderjarige bij alle procedures waarin deze verordening voorziet, wordt vertegenwoordigd en/of bijgestaan door een voogd.

\section{Artikel 9 lid 3 en 4} Opvangrichtlijn

3. Idem huidige wetgeving.

4. Idem huidige wetgeving.

\section{Artikel 9 lid 3 en 4 Opvangrichtlijn} 3. Schrappen.

4. Idem huidige wetgeving. 


\section{Artikel 11 lid 3 Opvangrichtlijn}

Niet-begeleide minderjarigen worden alleen in uitzonderlijke omstandigheden in bewaring gehouden. Alles wordt in het werk gesteld om de bewaring van niet-begeleide minderjarigen zo spoedig mogelijk op te heffen.

Niet-begeleide minderjarigen worden nooit in een gevangenis in bewaring gehouden. instellingen met personeel en faciliteiten die zijn afgestemd op de noden van personen van hun leeftijd.

Ingeval niet-begeleide minderjarigen toch in bewaring worden gehouden, zorgen de lidstaten ervoor dat zij afgescheiden van volwassenen worden gehuisvest.
Zij worden zoveel als mogelijk ondergebracht in

Niet-begeleide minderjarigen worden alleen in uitzonderlijke omstandigheden in bewaring gehouden. Alles wordt in het werk gesteld om de bewaring van niet-begeleide minderjarigen zo spoedig mogelijk op te heffen.

Niet-begeleide minderjarigen worden nooit in een gevangenis in bewaring gehouden.

Zij worden zoveel als mogelijk ondergebracht in instellingen met personeel dat rekening houdt met de rechten en noden van personen van hun leeftijd en faciliteiten die zijn aangepast aan nietbegeleide minderjarigen.

Ingeval niet-begeleide minderjarigen toch in bewaring worden gehouden, zorgen de lidstaten ervoor dat zij afgescheiden van volwassenen worden gehuisvest.

\section{Artikel 11 lid 2 (3)} Opvangrichtlijn

\section{Artikel 11 lid 2 (3) Opvangrichtlijn}

In bewaring gehouden minderjarigen moeten kunnen deelnemen aan vrijetijdsactiviteiten, met inbegrip van spel- en recreatieve activiteiten die passen bij hun leeftijd.

\section{Artikel 11 lid 6 Opvangrichtlijn}

In naar behoren gemotiveerde gevallen mogen de lidstaten voor een zo kort mogelijke, redelijke termijn afwijken van de derde alinea van lid 2 lid 4 en de eerste alinea van lid 5 , wanneer de verzoeker in bewaring wordt gehouden aan een grenspost of in een transitzone, tenzij het gaat om de in artikel 43 van Richtlijn 2013/32/EU bedoelde gevallen.
Het recht van in bewaring gehouden minderjarigen op onderwijs moet worden gewaarborgd en zij moeten kunnen deelnemen aan vrijetijdsactiviteiten, met inbegrip van spel- en recreatieactiviteiten die passen bij hun leeftijd.

\section{Artikel 11 lid 6 Opvangrichtlijn}

In naar behoren gemotiveerde gevallen mogen de lidstaten voor een zo kort mogelijke, redelijke termijn afwijken van de derde alinea van lid 2 lid 4 en de eerste alinea van lid 5 , wanneer de verzoeker in bewaring wordt gehouden aan een grenspost of in een
Artikel 11 lid 3 Opvangrichtlijn

Schrappen
Artikel 11 lid 2 (3) Opvangrichtlijn

Schrappen transitzone, tenzij het gaat om de in artikel 41 van Verordening (EU) $\mathrm{XXX} / \mathrm{XXX}$ [verordening asielprocedures] bedoelde gevallen.

\section{Artikel 11 lid 6 Opvangrichtlijn}

In naar behoren gemotiveerde gevallen mogen de lidstaten voor een zo kort mogelijke, redelijke termijn afwijken van de eerste alinea van lid 5 , wanneer de verzoeker in bewaring wordt gehouden aan een grenspost of in een transitzone. 


\section{Noten}

1 Europese Commissie persmededeling, 'Towards a Sustainable and Fair Common European Asylum System', europa.eu, 4 mei 2016, http://europa.eu/rapid/press-release_IP-16-1620_en.htm.

2 Europese Commissie, Questions \& Answers: Reforming the Common European Asylum System, 4 mei 2016, MEMO/16/1621.

3 A. Casarico, G. Facchini en C. Testa, 'Asylum policy and illegal immigration: perspectives and challenges', DICE report 14(4), 2016, 15; Europese Commissie, Communicatie naar het Europees Parlement en de Raad, Towards a Reform of The Common European Asylum System and Enhancing Legal Avenues to Europe, 6 april 2016, COM(2016) 197 final, 4.

4 De EU gebruikt veelal de noemer 'verzoeker om internationale bescherming' eerder dan 'asielzoeker'. Hierna wordt gekozen voor 'asielzoeker', ter bevordering van een vlotte leesbaarheid. Asielzoekers zijn zij die een vluchtelingenstatus aanvragen opdat ze officieel in een land kunnen verblijven. Een vluchteling is kort gesteld iemand die een internationale grens oversteekt om veiligheid te zoeken in een ander land. Een migrant, daarentegen, kiest ervoor om te verhuizen. Niet zozeer vanwege een directe dreiging, maar voornamelijk om zijn of haar leven te verbeteren, bijvoorbeeld door werk te vinden. Zie: UN High Commissioner for Refugees (UNHCR), Vluchteling of migrant: terminologie, https://www.unhcr.org/be/wpcontent/uploads/sites/46/2018/o1/UNHCR-Terminologie-NL.pdf.

5 Sommige auteurs verkiezen de term 'secundaire migratie' of 'secondary movement'. Zie: J.-P. Brekke, 'Stuck in transit: secondary migration of asylum seekers in Europe, national differences and the Dublin Regulation', Journal of Refugee Studies 28(2), 2014, 146; R. Bruin, S.G. Kok en A. Terlouw, 'Dublin: blind interstatelijk vertrouwen is een fictie: over inwilligingspercentages en overdrachten', Justitiële Verkenningen 41(3), 2015, 74, vn. 9.

6 Europese Commissie, Communicatie naar het Europees Parlement en de Raad, Towards a Reform of The Common European Asylum System and Enhancing Legal Avenues to Europe, 6 april 2016, COM(2016) 197 final, 2.

7 Ibidem, 8.

8 N.E. Nguema, 'La protection des mineurs migrants non-accompagnés en Europe', Revue du Centre de recherches et d'études sur les droits fondamentaux 7, 2015, 2; T. Strik, 'De externe dimensie van het EU migratiebeleid: uit het oog of uit het recht?', NTM 43(1), 2018, 64.

9 D. Gjipali, 'The External Dimension of EU Migration Policy', Academicus: International Scientific Journal MMXVII(15), 2017, 158.

10 Oxfam, 'You aren't human any more', Migrants expose the harrowing situation in Libya and the impact of European policies', Oxfam media briefing, 9 augustus 2017, https://www.oxfam.org/en/research/you-arent-human-any-more-migrants-exposeharrowing-situation-libya-and-impact-eu.

11 B. Parusel, 'Unaccompanied Minors in the European Union - Definitions, Trends and Policy Overview', Social Work and Society International Online Journal 15, 2017, 1-15; G.G. Valtolina en M. D'Odorico, 'Crossing Alone the Mediterranean Sea, Some Critical Issues About Unaccompanied Minors in Europe', Revista Interdisciplinar da Mobilidade Humana 25, $2017,79$.

12 N. Koffeman en L. Hillary, 'Mensenrechtelijke zorgen bij de plannen voor herziening van het Gemeenschappelijk Europees Asielsysteem', NTM 43(1), 2018, 113.

13 S. Kok, 'Hoe functioneert het Dublinsysteem? Over de weerbarstige praktijk', A\&MR 6(7), 2016, 291-297.

14 ECRE, Comments on the Commission Proposal for a Dublin IV Regulation (Com(2016) 270), oktober 2016, 2; N. Koffeman en L. Hillary, 'Mensenrechtelijke zorgen bij de plannen voor herziening van het Gemeenschappelijk Europees Asielsysteem', NTM 43(1), 2018, 131 .

15 R. O’Donnell en J. Kanics, 'Separated and Unaccompanied Children in the EU’, Forced Migration Review 51, $2016,75$.

16 Nochtans is de problematiek van de niet-begeleide minderjarige vreemdeling niet nieuw, ook tijdens de twee wereldoorlogen en tijdens Europese burgeroorlogen, zoals de Spaanse burgeroorlog, kwam deze voor. Zie: J. Balliauw, 'Migratie doet de EU op haar grondvesten daveren', VRT NWS, 9 december 2018, https://www.vrt.be/vrtnws/nl/2018/12/o7/migratie-doet-de-eu-opzijn-grondvesten-daveren/; C. Menjivar en K.M. Perreira, 'Undocumented and Unaccompanied: Children of Migration in the European Union and the United States', Journal of Ethnic and Migration Studies, 2017, 7.

17 A. Chomsky, 'A central American drama in four facts', in M. Lopez-Stafford Levy (red.), Children from the other America, Rotterdam: Sense Publishers 2016, 23-24; UN High Commissioner for Refugees (UNHCR), Children on the Run, Unaccompanied Children leaving Central America and Mexico and the Need for International Protection, 2001-, http://www.unhcr.org/about-us/background/56fc266f4/children-on-the-run-full-report.html, 114 p.

18 UN High Commissioner for Refugees (UNHCR), Children on the Run, Unaccompanied Children leaving Central America and Mexico and the Need for International Protection, 2001-, http://www.unhcr.org/about-us/background/56fc266f4/children-onthe-run-full-report.html.

19 J. Balliauw, 'Migratie doet de EU op haar grondvesten daveren', VRT NWS, 9 december 2018, https://www.vrt.be/vrtnws/nl/2018/12/o7/migratie-doet-de-eu-op-zijn-grondvesten-daveren/; L. Collins, 'Europe's Child Refugee Crisis', The New Yorker, 27 februari 2017, https://www.newyorker.com/magazine/2017/02/27/europes-child-refugeecrisis; Eurostat news release, 'Almost 20.00o Unaccompanied Minors Among Asylum Seekers Registered in the EU in 2018', ec.europa.eu, 26 april 2019, https://ec.europa.eu/eurostat/documents/2995521/9751525/3-26042019-BP-EN.pdf/291c8e8745b5-4108-920d-7d702c1d6990.

20 K. Byrne, 'Migrant, Refugee or Minor? It Matters for Children in Europe', FMReview, 2017, 94; L. Collins, 'Europe's Child 
Refugee Crisis', The New Yorker, 27 februari 2017, https://www.newyorker.com/magazine/2017/02/27/europes-child-refugeecrisis; S. Devi, 'Unaccompanied Migrant Children at Risk across Europe', World Report 387, 2016, 2590.

21 Eurostat news release, 'Over 31.00o Unaccompanied Minors Among Asylum Seekers Registered in the EU in 2017', ec.europa.eu, 16 mei 2018, https://ec.europa.eu/eurostat/documents/2995521/8895109/3-16052018-BP-EN.pdf/ec4cc3d7-c1774944-964f-d85401e55ad9.

22 Oxfam, 'You aren't human any more', Migrants expose the harrowing situation in Libya and the impact of European policies', Oxfam media briefing, 9 augustus 2017, https://www.oxfam.org/en/research/you-arent-human-any-more-migrants-exposeharrowing-situation-libya-and-impact-eu.

23 HvJ 28 februari 2017, T-192/16, ECLI:EU:T:2017:128, N.F./Europese Raad; Europese Raad persmededeling, 'Verklaring EUTurkije', consilium.europa.eu, 18 maart 2016, https://www.consilium.europa.eu/nl/press/press-releases/2016/o3/18/eu-turkeystatement/; J. Wouters, C. Ryngaert, T. Ruys, en G. De Baere, International Law - A European Perspective, Oxford: Hart 2019, 697.

24 B. De Vroey, 'Twee jaar EU-Turkije-akkoord: een bedenkelijk succes', VRT NWS, 16 maart 2018, https://www.vrt.be/vrtnws/nl/2018/03/16/bedenkelijk-succes-/.

25 https://ec.europa.eu/eurostat/tgm/table.do?tab=table\&init=1\&language=en\&pcode=tpso0194\&plugin=1.

26 R. Gladstone, '300,ooo Child Refugees and Migrants Traveled Alone in '15 and '16, U.N. Says', The New York Times, 17 mei 2017, https://www.nytimes.com/2017/05/17/world/americas/united-nations-children-refugees-migrants-trafficking.html.

27 L. Kestemont en P. Schoukens, Rechtswetenschappelijk schrijven, Leuven: Acco 2012, 25.

28 Ibidem, 26.

29 H. Tijssen, De juridische dissertatie onder de loep, Den Haag: Boom juridische uitgevers 2009, 173.

3o Deze criteria kunnen juridisch, maar ook niet-juridisch van aard zijn. Zie: L. Kestemont en P. Schoukens, Rechtswetenschappelijk schrijven, Leuven: Acco 2012, 50.

31 In het voorstel voor de Kwalificatieverordening richten enkel art. 22 en 36 zich op de NBMV (in verband met vertegenwoordiging), deze artikelen lijken over het algemeen echter vrij van kritiek.

32 N. Koffeman en L. Hillary, 'Mensenrechtelijke zorgen bij de plannen voor herziening van het Gemeenschappelijk Europees Asielsysteem', NTM 43(1), 2018, 114.

33 Hailbronner en Thym beweren zo dat art. 3 en verderop ook art. 5, 'particularly relevant' zijn voor het asiel- en migratiebeleid. Zie: L. Denys, Overzicht van het vreemdelingenrecht, Heule: Inni Publishers 2019, 553; K. Hailbronner en D. Thym, EU Immigration and asylum law- a commentary, München: C.H. Beck 2016, 1047; N. Koffeman en L. Hillary, 'Mensenrechtelijke zorgen bij de plannen voor herziening van het Gemeenschappelijk Europees Asielsysteem', NTM 43(1), 2018, 122-128; S. Sarolea, Droits de l'homme et migrations: de la protection au migrant aux droits de la personne migrante, Brussel: Bruylant $2006,157$.

34 Zo bijvoorbeeld in: EHRM 12 oktober 2006, nr. 13178/o3, Mubilanzila Mayeka en Kaniki Mitunga/België; EHRM 28 oktober 2010, nr. 41533/o8, Bubullima/Griekenland; EHRM 5 april 2011, nr. 8687/o8, Rahimi/Griekenland.

35 Europese Commissie persmededeling, 'Towards a Sustainable and Fair Common European Asylum System', europa.eu, 4 mei 2016, http://europa.eu/rapid/press-release_IP-16-1620_en.htm.

36 R. Bruin, S.G. Kok en A. Terlouw, 'Dublin: blind interstatelijk vertrouwen is een fictie: over inwilligingspercentages en overdrachten', Justitiële Verkenningen 41(3), 2015, 71.

37 J. Allsopp en E. Chase, 'Best Interests, Durable Solutions and Belonging: Policy Discourses Shaping the Futures of Unaccompanied Migrant and Refugee Minors Coming of Age in Europe', Journal of Ethnic and Migration Studies 45(2), 2019, 296; K. Pollet, 'Grondrechtenbescherming in de Dublin III-verordening: de doodsteek voor het Dublinsysteem?', in D. Vanheule (red.), Migratie en migrantenrecht - ontwikkelingen inzake arbeidsdiscriminatie, detachering van werknemers, kinderontvoering en de Dublinverordening, Brugge: Die Keure 2017, 125.

38 K. Pollet, 'Grondrechtenbescherming in de Dublin III-verordening: de doodsteek voor het Dublinsysteem?', in D. Vanheule (red.), Migratie en migrantenrecht - ontwikkelingen inzake arbeidsdiscriminatie, detachering van werknemers, kinderontvoering en de Dublinverordening, Brugge: Die Keure 2017, 125.

39 L. Collins, 'Europe's Child Refugee Crisis', The New Yorker, 27 februari 2017, https://www.newyorker.com/magazine/2017/02/27/europes-child-refugee-crisis; Eurostat news release, '63.300 Unaccompanied Minors Among Asylum Seekers Registered in the EU in 2016: over Half are Afghans or Syrians', europeanmigrationlaw.eu, 11 mei 2017

http://www.europeanmigrationlaw.eu/documents/Asylum\%20applicants\%2oconsidered\%2oto\%2obe\%2ounaccompanied\%2ominors.pdf.

40 C. Bauloz, M. Ineli-Ciger, S. Singer, en V. Stoyanova, 'Introducing the Second Phase of the Common European Asylum System', in C. Bauloz, M. Ineli-Ciger, S. Singer, en V. Stoyanova (red.), Seeking Asylum in the European Union, Leiden: Brill Nijhoff 2015, 5; M. den Heijer, J. Rijpma en T. Spijkerboer, 'Coercion, Prohibiton and Great Expectations: The Continuing Failure of the Common European Asylum System', Common Market Law Review 52, 2016, 609.

41 N. Koffeman en L. Hillary, 'Mensenrechtelijke zorgen bij de plannen voor herziening van het Gemeenschappelijk Europees Asielsysteem', NTM 43(1), 2018, 115. 
42 J. Allsopp en E. Chase, 'Best Interests, Durable Solutions and Belonging: Policy Discourses Shaping the Futures of Unaccompanied Migrant and Refugee Minors Coming of Age in Europe', Journal of Ethnic and Migration Studies 45(2), 2019, 296; C. Bauloz, M. Ineli-Ciger, S. Singer, en V. Stoyanova, 'Introducing the Second Phase of the Common European Asylum System', in C. Bauloz, M. Ineli-Ciger, S. Singer, en V. Stoyanova (red.), Seeking Asylum in the European Union, Leiden: Brill Nijhoff 2015, 2; P. Boeles, M. den Heijer, G. Lodder, en K. Wouters, European Migration Law, Antwerpen: Intersentia 2014, 248-249.

43 MYRIA, Europa in (asiel)crisis, Myriadocs, juni 2016, https://www.myria.be/files/Myriadocs-1-NL-Europaincrisis.pdf, 17.

44 Europese Commissie, Questions \& Answers: Reforming the Common European Asylum System, 4 mei 2016, MEMO/16/1621.

45 Europese Commissie, Communicatie naar het Europees Parlement en de Raad, Towards a Reform of The Common European Asylum System and Enhancing Legal Avenues to Europe, 6 april 2016, COM(2016) 197 final, 2, 8.

46 Europese Commissie, Questions \& Answers: Reforming the Common European Asylum System, 4 mei 2016, MEMO/16/1621.

47 Europese Commissie, Voorstel voor een verordening van het Europees Parlement en de Raad, tot vaststelling van de criteria en instrumenten om te bepalen welke lidstaat verantwoordelijk is voor de behandeling van een verzoek om internationale bescherming dat door een onderdaan van een derde land of een staatloze bij een van de lidstaten wordt ingediend (herschikking), 4 mei 2016, COM(2016) 270 final (hierna: Dublin IV-voorstel).

48 K. Pollet, 'Grondrechtenbescherming in de Dublin III-verordening: de doodsteek voor het Dublinsysteem?', in D. Vanheule (red.), Migratie en migrantenrecht - ontwikkelingen inzake arbeidsdiscriminatie, detachering van werknemers, kinderontvoering en de Dublinverordening, Brugge: Die Keure 2017, 125.

49 Europese Commissie, Voorstel voor een verordening van het Europees Parlement en de Raad, betreffende de instelling van 'Eurodac' voor de vergelijking van vingerafdrukken ten behoeve van een doeltreffende toepassing van [Verordening (EU) nr. $604 / 2013$ tot vaststelling van de criteria en instrumenten om te bepalen welke lidstaat verantwoordelijk is voor de behandeling van een verzoek om internationale bescherming dat door een onderdaan van een derde land of een staatloze bij een van de lidstaten wordt ingediend], voor de identificatie van een illegaal verblijvende onderdaan van een derde land of staatloze en betreffende verzoeken van rechtshandhavingsinstanties van de lidstaten en Europol om vergelijkingen van Eurodac-gegevens ten behoeve van rechtshandhaving (herschikking), 4 mei 2016, COM(2016) 272 final.

50 L. Roots, 'The New EURODAC Regulation: Fingerprints as a Source of Informal Discrimination', Baltic Journal of European Studies 5(2), 2015, 108.

51 Europese Commissie, Voorstel voor een verordening van het Europees Parlement en de Raad, inzake het Asielagentschap van de Europese Unie en tot intrekking van Verordening (EU) nr. 439/2010, 4 mei 2016, COM(2016) 271 final.

52 F. Comte, 'A New Agency is Born in the European Union: the European Asylum Support Office', European Journal of Migration and Law 1(4), 2010, 373.

53 Europese Commissie, Voorstel voor een verordening van het Europees Parlement en de Raad tot vaststelling van een gemeenschappelijke procedure voor internationale bescherming in de Unie en tot intrekking van Richtlijn 2013/32/EU, 13 juli 2016, $\operatorname{COM}(2016) 467$ final (Voorstel Procedureverordening).

54 M. Reneman, 'Implementatie van de herziene Asielprocedurerichtlijn: een nieuwe beslissystematiek en meer waarborgen voor asielzoekers', Nederlands Tijdschrift voor Europees Recht 2015(8), 2015, 251.

55 Europese Commissie, Voorstel voor een verordening van het Europees Parlement en de Raad, inzake normen voor de erkenning van onderdanen van derde landen of staatlozen als personen die internationale bescherming genieten, voor een uniforme status voor vluchtelingen of voor personen die in aanmerking komen voor subsidiaire bescherming, en voor de inhoud van de verleende bescherming, alsook tot wijziging van Richtlijn 2003/109/EG van de Raad van 25 november 2003 betreffende de status van langdurig ingezeten onderdanen van derde landen, 13 juli 2016, $\mathrm{COM(2016)} 466$ final.

56 A. Maes, 'Asielrecht in de kering: de nieuwe Dublinverordening en de nieuwe kwalificatierichtlijn', in D. Vanheule (red.), Migratie en migrantenrecht - ontwikkelingen inzake arbeidsdiscriminatie, detachering van werknemers, kinderontvoering en de Dublinverordening, Brugge: Die Keure 2017, 120.

57 Europese Commissie, Voorstel voor een richtlijn van het Europees Parlement en de Raad, tot vaststelling van normen voor de opvang van verzoekers om internationale bescherming (herschikking), 13 juli 2016, COM(2016) 465 final (Voorstel Opvangrichtlijn).

58 N. Koffeman en L. Hillary, 'Mensenrechtelijke zorgen bij de plannen voor herziening van het Gemeenschappelijk Europees Asielsysteem', NTM 43(1), 2018, 117.

59 Deze procedure houdt in dat eerst een wetsvoorstel door de Europese Commissie gelanceerd wordt. Na publicatie van het wetsvoorstel stuurt de Commissie dit naar het Europees Parlement; het Parlement is de eerste die een standpunt mag innemen. In een eerste lezing nemen zij amendementen aan en sturen deze door naar de Raad van de Europese Unie (ook wel 'de Raad' of 'de Raad van Ministers' genoemd). De Raad neemt dan op zijn beurt ook een standpunt in en zegt met welke amendementen van het Parlement hij al dan niet akkoord gaat. Daarna is de eerste lezing voltooid. Als uit deze eerste lezing blijkt dat de Raad en het Parlement overeenkomen, dan wordt de wet aangenomen. Als blijkt dat dat niet zo is, dan beginnen het Parlement en de Raad aan een tweede lezing volgens hetzelfde mechanisme als dat van de eerste lezing. Als er na een tweede lezing geen akkoord is gevonden, wordt een bemiddelingscomité aangesteld dat onderhandelt tot een oplossing gevonden is. Indien dat niet gebeurt, wordt er geen wet aangenomen. Als dat wel gebeurt, wordt er mogelijk wel een wet aangenomen en treedt ze, als het om een verordening gaat, onmiddellijk in werking, in geval van richtlijnen wordt met een vooraf afgesproken implementatieperiode 
gewerkt. Zie: art. 294 Verdrag betreffende de werking van de Europese Unie (VWEU) van 26 oktober 2012.

60 Zo bijvoorbeeld: Europees Parlement, Verslag over het voorstel voor een richtlijn van het Europees Parlement en de Raad tot vaststelling van normen voor de opvang van verzoekers om internationale bescherming (herschikking), 10 mei 2017, A80186/2017; Europees Parlement, Verslag over het voorstel voor een verordening van het Europees Parlement en de Raad tot vaststelling van de criteria en instrumenten om te bepalen welke lidstaat verantwoordelijk is voor de behandeling van een verzoek om internationale bescherming dat door een onderdaan van een derde land of een staatloze bij een van de lidstaten wordt ingediend (herschikking), 6 november 2017, A8-0345/2017.

61 Raad van de Europese Unie, Nota, 26 februari 2019, 6600/19, 3.

62 K. Pollet, 'All in vain? The fate of EP positions on asylum reform after the European elections', EU Immigration and Asylum Law and Policy Blog, 23 mei 2019, http://eumigrationlawblog.eu/all-in-vain-the-faith-of-ep-positions-on-asylum-reform-afterthe-european-elections/.

63 G. Cardol, Ontheemd, vreemd en minderjarig - Het recht op ontwikkeling van de alleenstaande minderjarige vreemdeling in (inter)nationale wet- en regelgeving, Nijmegen: Wolf Legal Publishers 2005, 15.

64 Dit al dan niet ter implementatie van supra- of internationale normen. Zo wordt de Belgische definitie voor het eerst gegeven in de Voogdijwet. Art. 5-5/1 Programmawet (I) 24 december 2002 Titel XIII Hoofdstuk VI: Voogdij over niet-begeleide minderjarige vreemdelingen, B.S. 31 december 2002.

65 K. Fournier, 'De voogdijwet voor niet-begeleide minderjarige vreemdelingen: terug- en vooruitblik', in D. Vanheule (red.), Migratie en migrantenrecht - ontwikkelingen inzake arbeidsdiscriminatie, detachering van werknemers, kinderontvoering en de Dublinverordening, Brugge: Die Keure 2017, 186; C. Gimeno-Monterde en J.D. Guttierez-Sanchez, 'Fostering Unaccompanied Migrating Minors: A Cross-border Comparison', Children and Youth Services Review 99, 2019, 41.

66 J. Allsopp en E. Chase, 'Best Interests, Durable Solutions and Belonging: Policy Discourses Shaping the Futures of Unaccompanied Migrant and Refugee Minors Coming of Age in Europe', Journal of Ethnic and Migration Studies 45(2), 2019, 296.

67 UN High Commissioner for Refugees (UNHCR), Working with Unaccompanied Children, A Community Based Approach, mei 1996, 97 p, http://www.refworld.org/docid/4a54bc24d.html; B. Verhaegen, 'De Wettelijke Vertegenwoordiging van Nietbegeleide Minderjarige Vreemdelingen', Jura Falconis 40(4), 2004, 877.

68 De Resolutie is niet bindend, maar wordt als een belangrijke invloed op de ontwikkeling van het GEAS gezien. Zie: R. Farrugia en K. Touzenis, 'The international protection of unaccompanied and separated migrant and asylum-seeking children in Europe', in J. Kanics, D.S. Hernandez en K. Touzenis (red.), Migrating alone- Unaccompanied and separated children's migration to Europe, Unesco Publishing, 2010, 43.

69 Resolutie van de Raad nr. 97/C 221/o3 van 26 juni 1997 inzake niet-begeleide minderjarige onderdanen van derde landen; N.E. Nguema, 'La protection des mineurs migrants non-accompagnés en Europe', Revue du Centre de recherches et d'études sur les droits fondamentaux 7, 2015, 7.

70 Art. 1 Resolutie van de Raad nr. 97/C 221/o3 van 26 juni 1997 inzake niet-begeleide minderjarige onderdanen van derde landen.

71 Zie bijvoorbeeld ook het voorstel voor de Procedureverordening en het voorstel voor de nieuwe Opvangrichtlijn. Zie: B. Parusel, 'Unaccompanied Minors in the European Union - Definitions, Trends and Policy Overview', Social Work and Society International Online Journal 15, 2017, 1-15.

72 Art. 2 Dublin IV-voorstel.

73 D. Androff, 'The Human Rights of Unaccompanied Minors in the USA from Central America', Journal of Human Rights and Social Work 1(2), 2016, 71; A. Beduschi, 'Vulnerability on Trial: Protection of Migrant Children's Rights in the Jurisprudence of International Human Rights Courts', Boston University International Law Journal 36(1), 2018, 57; J.Y. Carlier en S. Sarolea, Droit des étrangers, Brussel: Larcier 2016, 531; D.S. Hernandez, 'Analyse d'une catégorie juridique récente: le mineur étranger non accompagné, séparé ou isolé', Revue européenne des migrations 30, 2014, 18.

74 N.E. Nguema, 'La protection des mineurs migrants non-accompagnés en Europe', Revue du Centre de recherches et d'études sur les droits fondamentaux 7, 2015, 1.

75 Art. 1 Kinderrechtenverdrag.

76 The African Child Policy Forum, Definition of the Child: The International/regional Legal Framework, 2013, http://www.youthpolicy.org/wp-content/uploads/library/2013_Africa_Child_Law_Comparison_Eng.pdf.

77 B. Verhaegen, 'De Wettelijke Vertegenwoordiging van Niet-begeleide Minderjarige Vreemdelingen', Jura Falconis 40(4), 2004,876 .

$\mathbf{7 8}$ Ibidem, 875 .

79 Resolutie van de Raad nr. 97/C 221/03 van 26 juni 1997 inzake niet-begeleide minderjarige onderdanen van derde landen.

8o Bijvoorbeeld in art. 2 Voorstel voor Kwalificatie Verordening.

81 N.E. Nguema, 'La protection des mineurs migrants non-accompagnés en Europe', Revue du Centre de recherches et d'études sur les droits fondamentaux 7, 2015,7. 
82 M.A. Kenny en A. Loughry, 'Addressing the limitations of age determination for unaccompanied minors: A way forward', Children and Youth Services Review 92, 2018, 15; G.G. Valtolina en M. D’Odorico, 'Crossing Alone the Mediterranean Sea, Some Critical Issues About Unaccompanied Minors in Europe', Revista Interdisciplinar da Mobilidade Humana 25, $2017,88$.

83 N. Mole en C. Meredith, Asylum and the European Convention on Human Rights, Straatsburg, Council of Europe Publishing, 2010, 189 .

84 J. Bhabha, 'Arendt's children: do today's migrant children have a right to have rights?', Human Rights Quarterly 31, 2009, 427; C. Gimeno-Monterde en J.D. Guttierez-Sanchez, 'Fostering Unaccompanied Migrating Minors: A Cross-border Comparison', Children and Youth Services Review 99, 2019, 38; G.G. Valtolina en M. D'Odorico, 'Crossing Alone the Mediterranean Sea, Some Critical Issues About Unaccompanied Minors in Europe', Revista Interdisciplinar da Mobilidade Humana 25, $2017,88$.

85 Programmawet (I) 24 december 2002 Titel XIII Hoofdstuk VI: Voogdij over niet-begeleide minderjarige vreemdelingen, B.S. 31 december 2002.

86 N. Mole en C. Meredith, Asylum and the European Convention on Human Rights, Straatsburg, Council of Europe Publishing, 2010, 189; N.E. Nguema, 'La protection des mineurs migrants non-accompagnés en Europe', Revue du Centre de recherches et d'études sur les droits fondamentaux 7, 2015, 4.

87 Zie ook EHRM 11 december 2014, nr. 70586/11, Mohamad/Griekenland; EHRM 22 november 2016, nrs. 25794/13 en 28151/13, Abdullahi Elmi en Aweys Abubakar/Malta; N. Mole en C. Meredith, Asylum and the European Convention on Human Rights, Straatsburg, Council of Europe Publishing, 2010, 189.

88 M.A. Kenny en A. Loughry, 'Addressing the limitations of age determination for unaccompanied minors: A way forward', Children and Youth Services Review 92, 2018, 15.

89 Zie art. 16 van het Kinderrechtenverdrag.

90 Zo zouden röntgenstralen de gezondheid van het kind kunnen schaden. Zie: art. 24 van het Kinderrechtenverdrag; N.E. Nguema, 'La protection des mineurs migrants non-accompagnés en Europe', Revue du Centre de recherches et d'études sur les droits fondamentaux $7,2015,4$.

91 J. Bhabha, 'Arendt's children: do today's migrant children have a right to have rights?', Human Rights Quarterly 31, 2009, 427; N.E. Nguema, 'La protection des mineurs migrants non-accompagnés en Europe', Revue du Centre de recherches et d'études sur les droits fondamentaux 7, 2015, 4.

92 B. Parusel, 'Unaccompanied Minors in the European Union - Definitions, Trends and Policy Overview', Social Work and Society International Online Journal 15, 2017, 1-15.

93 D. Androff, 'The Human Rights of Unaccompanied Minors in the USA from Central America', Journal of Human Rights and Social Work 1(2), 2016, 71; J.Y. Carlier en S. Sarolea, Droit des étrangers, Brussel: Larcier 2016, 531; C. Menjivar en K.M. Perreira, 'Undocumented and Unaccompanied: Children of Migration in the European Union and the United States', Journal of Ethnic and Migration Studies, 2017, 5.

94 B. Verhaegen, 'De Wettelijke Vertegenwoordiging van Niet-begeleide Minderjarige Vreemdelingen', Jura Falconis 40(4), 2004, 877 .

95 D. Androff, 'The Human Rights of Unaccompanied Minors in the USA from Central America', Journal of Human Rights and Social Work 1(2), 2016, 71.

96 G. Cardol, Ontheemd, vreemd en minderjarig - Het recht op ontwikkeling van de alleenstaande minderjarige vreemdeling in (inter)nationale wet- en regelgeving, Nijmegen: Wolf Legal Publishers 2005, 15; C. Menjivar en K.M. Perreira,

'Undocumented and Unaccompanied: Children of Migration in the European Union and the United States', Journal of Ethnic and Migration Studies, 2017, 5 .

97 Art. 1 Resolutie van de Raad nr. 97/C 221/o3 van 26 juni 1997 inzake niet-begeleide minderjarige onderdanen van derde landen.

98 B. Verhaegen, 'De Wettelijke Vertegenwoordiging van Niet-begeleide Minderjarige Vreemdelingen', Jura Falconis 40(4), 2004,877 .

99 J. Freccero, D. Biswas, A. Whiting, K. Alrabe en K. Thuy Seelinger, 'Sexual Exploitation of Unaccompanied Migrant and Refugee Boys in Greece: Approaches to Prevention', PLOS Medicine 14, 2017, 2; N.E. Nguema, 'La protection des mineurs migrants non-accompagnés en Europe', Revue du Centre de recherches et d'études sur les droits fondamentaux 7, $2015,1$.

100 Zo stelt de Belgische Programmawet bijvoorbeeld dat de minderjarige geen ouderlijke toestemming heeft om te reizen (1) en dat hij niet in een bevolkingsregister ingeschreven mag zijn (2). Zie: art. 5/1 Programmawet (I) 24 december 2002 Titel XIII Hoofdstuk VI: Voogdij over niet-begeleide minderjarige vreemdelingen, B.S. 31 december 2002.

101 D.S. Hernandez, 'Analyse d'une catégorie juridique récente: le mineur étranger non accompagné, séparé ou isolé', Revue européenne des migrations 30, 2014, 20; MYRIA, Migratie in cijfers en in rechten 2015, Myriadocs, 3 september 2015, https://www.myria.be/nl/publicaties/migratie-in-cijfers-en-in-rechten-2015, 90; N.E. Nguema, 'La protection des mineurs migrants non-accompagnés en Europe', Revue du Centre de recherches et d'études sur les droits Fondamentaux 7, 2015, 1-2.

102 J. Freccero, D. Biswas, A. Whiting, K. Alrabe en K. Thuy Seelinger, 'Sexual Exploitation of Unaccompanied Migrant and Refugee Boys in Greece: Approaches to Prevention', PLOS Medicine 14, 2017, 4; S. Swart, 'Unaccompanied minor refugees and the protection of their socio-economic rights under human rights law', Afr. Hum. Rts. L.J. 103, 2009, 114; M.F. Valette, 'La vulnerabilité de l'enfant au gré des migrations', $R T D H$ 89, 2012, 104-105; G.G. Valtolina en M. D'Odorico, 'Crossing Alone the 
Mediterranean Sea, Some Critical Issues About Unaccompanied Minors in Europe', Revista Interdisciplinar da Mobilidade Humana 25, 2017, 79.

103 J. Allsopp en E. Chase, 'Best Interests, Durable Solutions and Belonging: Policy Discourses Shaping the Futures of Unaccompanied Migrant and Refugee Minors Coming of Age in Europe', Journal of Ethnic and Migration Studies 45(2), 2019, 294; J. Ataiants, C. Cohen, A. Henderson Riley, J. Tellez Lieberman, M.C. Reidy en M. Chilton, 'Unaccompanied Children at the United States Border, a Human Rights Crisis that can be Addressed with Policy Change', Journal Immigrant Minority Health 20(4), 2018; K. Byrne, 'Migrant, Refugee or Minor? It Matters for Children in Europe', FMReview, 2017, 94-95.

104 A. Vanrenterghem, 'Aantal niet-begeleide minderjarige vreemdelingen dat verdween lag nog nooit zo hoog', VRT NWS, 30 april 2019, https://www.vrt.be/vrtnws/nl/2019/04/30/nooit-verdwenen-meer-niet-begeleide-minderjarige-vreemdelingen-i/.

105 Deze Verklaring is echter niet juridisch bindend. Zie: art. 14.1 UVRM; A. Casarico, G. Facchini en C. Testa, 'Asylum policy and illegal immigration: perspectives and challenges', DICE report 14(4), 2016, 14; 54; J. Lenart, 'Fortress Europe': compliance of the Dublin II regulation with the European Convention for the Protection of Human Rights and Fundamental Freedoms', Utrecht Journal of International and European Law 28(75), 2012, 8.

106 Ze stelt immers dat 'eenieder aanspraak kan maken op de rechten en vrijheden uit de Verklaring, zonder onderscheid van welke aard ook', bijgevolg speelt de leeftijd van het individu in principe geen rol. Alle dertig artikelen uit de Verklaring zijn neutraal wat betreft de leeftijd. Enkel art. 16 UVRM, in verband met het recht om te huwen, is leeftijdsgebonden. Zie: art. 2 lid 1 UVRM; J. Bhabha, 'Arendt's children: do today's migrant children have a right to have rights?', Human Rights Quarterly 31, 2009, 420.

107 Dit Verdrag werd aangevuld met het Protocol van New York betreffende de Status van Vluchtelingen van 31 januari 1967. Zie: Internationaal Verdrag betreffende de Status van Vluchtelingen van 28 juli 1951 (Vluchtelingenverdrag); Protocol van New York betreffende de Status van Vluchtelingen van 31 januari 1967; J. Allsopp en E. Chase, 'Best Interests, Durable Solutions and Belonging: Policy Discourses Shaping the Futures of Unaccompanied Migrant and Refugee Minors Coming of Age in Europe', Journal of Ethnic and Migration Studies 45(2), 2019, 296; J. Wouters, C. Ryngaert, T. Ruys, en G. De Baere, International Law - A European Perspective, Oxford: Hart 2019, 692.

108 Aanvankelijk waren de verplichtingen voor de partijen bij het Verdrag beperkt tot vluchtelingensituaties die reeds bestonden voor 1951. Doorheen de tijd rees het aantal vluchtelingen en werd de nood ervaren om het Vluchtelingenverdrag ook van toepassing te laten zijn op 'nieuwe' vluchtelingen. Het Protocol van New York heft deze tijdsbeperking dan ook op. Zie: art. 1 Vluchtelingenverdrag, UN High Commissioner FOR Refugees (UNHCR), Handbook and Guidelines on Procedures and Criteria for Determining Refugee Status (reissued), december 2011, https://www.unhcr.org/3d58e13b4.html, 5-6.

109 G. Cardol, Ontheemd, vreemd en minderjarig - Het recht op ontwikkeling van de alleenstaande minderjarige vreemdeling in (inter)nationale wet- en regelgeving, Nijmegen: Wolf Legal Publishers 2005, 148.

110 Art. 39.2 Internationaal Verdrag betreffende de Status van Vluchtelingen; UN High Commissioner FOR Refugees (UNHCR), States Parties to the Convention relating to the Status of Refugees and the 1967 Protocol, 5 p., http://www.unhcr.org/protection/basic/3b73bod63/states-parties-1951-convention-its-1967-protocol.html.

111 J. Lenart, 'Fortress Europe': compliance of the Dublin II regulation with the European Convention for the Protection of Human Rights and Fundamental Freedoms', Utrecht Journal of International and European Law 28(75), 2012, 10; S.F. Nicolosi, 'Going unnoticed? Diagnosing the right to asylum in the Charter of Fundamental Rights of the European Union', European Law Journal 23 (1-2), 2017, 94.

112 S.F. Nicolosi, 'Going unnoticed? Diagnosing the right to asylum in the Charter of Fundamental Rights of the European Union', European Law Journal 23 (1-2), 2017, 98; J. Wouters, C. Ryngaert, T. Ruys, en G. De Baere, International Law - A European Perspective, Oxford: Hart 2019, 692.

113 Europese Raad, Conclusies van het voorzitterschap van de Europese Raad van Tampere, 15 en 16 oktober 1999, paragraaf 13 .

114 HvJ 2 maart 2010, C-175/o8, C-176/08, C-178/08 en C-179/o8, ECLI:EU:C:2010:105, Abdulla, Hasan, Adem, Rashi en Jama/Duitsland, §52; C. Matera, 'The Influence of International Organisations on the EU's Area of Freedom, Security and Justice: A First Inquiry', in R.A. Wessel en S. Blockmans (red.), Between Autonomy and Dependence, Den Haag: Springer 2014, 276.

115 Dit verdrag is in werking getreden op 2 september 1990. Zie: J. Allsopp en E. Chase, 'Best Interests, Durable Solutions and Belonging: Policy Discourses Shaping the Futures of Unaccompanied Migrant and Refugee Minors Coming of Age in Europe', Journal of Ethnic and Migration Studies 45(2), 2019, 296; J. Wouters, C. Ryngaert, T. Ruys, en G. De Baere, International Law - A European Perspective, Oxford: Hart 2019, 690.

116 Lees ook: 'De Commissie neemt de normen van het Verdrag van de Verenigde Naties inzake de rechten van het kind als uitgangspunt voor maatregelen van welke aard dan ook op het gebied van niet-begeleide minderjarigen'. Zie: Europese Commissie, Actieplan EU niet-begeleide minderjarigen (2010-2014), https://www.rijksoverheid.nl/documenten/richtlijnen/2011/o7/o7/actieplan-eu-niet-begeleide-minderjarigen-2010-2014, 3; N.E. Nguema, 'La protection des mineurs migrants non-accompagnés en Europe', Revue du Centre de recherches et d'études sur les droits fondamentaux 7, 2015, 7; W. Vandenhole, 'Editoriaal - Kinderrechten op het scherpst van de snede', TJF (1), $2016,3$.

117 Art. 22.1 Kinderrechtenverdrag: 'Staten die partij zijn tot het verdrag de passende maatregelen moeten nemen om te waarborgen dat een vluchtelingenkind passende bescherming en humanitaire bijstand krijgt bij het genot van zijn [rechten erkend in internationale akten].' Het artikel stipuleert bovendien '... ongeacht of het al dan niet door zijn ouders of door iemand anders wordt begeleid'; C. Smyth, 'Is the right of the child to liberty safeguarded in the common European Asylum System?', European Journal of Migration and Law 15, 2013, 121. 
118 J. Bhabha, 'Arendt's children: do today's migrant children have a right to have rights?', Human Rights Quarterly 31, 2009, 426; G. Cardol, Ontheemd, vreemd en minderjarig - Het recht op ontwikkeling van de alleenstaande minderjarige vreemdeling in (inter)nationale wet- en regelgeving, Nijmegen: Wolf Legal Publishers 2005, 89.

119 G. Cardol, Ontheemd, vreemd en minderjarig - Het recht op ontwikkeling van de alleenstaande minderjarige vreemdeling in (inter)nationale wet- en regelgeving, Nijmegen: Wolf Legal Publishers 2005,73; C. van Os, 'De relevantie van het Kinderrechtenverdrag voor minderjarige vreemdelingen', Justitiële Verkenningen 38(6), 2012, 71.

120 R. Farrugia en K. Touzenis, 'The international protection of unaccompanied and separated migrant and asylum-seeking children in Europe', in J. Kanics, D.S. Hernandez en K. Touzenis (red.), Migrating alone- Unaccompanied and separated children's migration to Europe, Unesco Publishing, 2010, 23; M. Kalverboer, D. Beltman, C. van Os, en E. Zijlstra, 'The Best Interests of the Child in Cases of Migration: Assessing and Determining the Best Interests of the Child in Migration', International Journal of Children's Rights 25, 2017, 117.

121 Sinds de ratificatie van Somalië in 2015 is het Kinderrechtenverdrag met zijn 196 ratificaties zelfs het meest geratificeerde mensenrechtelijke verdrag ter wereld. Zie: Status of the Convention on the Rights of the Child,

https://treaties.un.org/pages/ViewDetails.aspx?src=TREATY\&mtdsg_no=IV-11\&chapter=4\&lang=en; J. Wouters, C. Ryngaert, T. Ruys, en G. De Baere, International Law - A European Perspective, Oxford: Hart 2019, 690.

122 Mondiaal Pact voor Veilige, Ordelijke en Reguliere Migratie van 11 juli 2018 (Migratiepact); S. Vercruysse, 'Wat staat er in het migratiepact en waarom keurt de regering het nog niet goed?', VRT NWS, 17 november 2018,

https://www.vrt.be/vrtnws/nl/2018/11/17/n-va-blijft-belgische-steun-aan-vn-migratiepact-tegenhouden/.

123 Desondanks kan het Pact wel juridische gevolgen hebben, bijvoorbeeld wanneer rechters het via hun rechtspraak laten binnensluipen. Zie: r.o. 7 en 15 Migratiepact; D. Vanheule, 'Het Global Compact for Safe, Orderly and Regular Migration', $R W$ 82(25), 2019, 962; S. Vercruysse, 'Wat staat er in het migratiepact en waarom keurt de regering het nog niet goed?', VRT NWS, 17 november 2018, https://www.vrt.be/vrtnws/nl/2018/11/17/n-va-blijft-belgische-steun-aan-vn-migratiepact-tegenhouden/.

124 U. Laessing en A. Rinke, 'More than 160 countries sign UN migration pact; U.S. and others opt out', The Globe and Mail, 10 december 2018, https://www.theglobeandmail.com/world/article-more-than-16o-countries-sign-un-migration-pact-us-andothers-reject/; D. Vanheule, 'Het Global Compact for Safe, Orderly and Regular Migration', RW 82(25), $2019,962$.

125 G. Gotev, 'Nine EU members stay away from UN Migration Pact', Euractiv, 20 december 2018,

https://www.euractiv.com/section/global-europe/news/nine-eu-members-stay-away-from-un-migration-pact/.

126 Doelstelling 7 (f) van het Migratiepact: 'Protect unaccompanied and separated children at all stages of migration through the establishment of specialized procedures for their identification, referral, care and family reunification, and provide access to health care services, including mental health, education, legal assistance and the right to be heard in administrative and judicial proceedings, including by swiftly appointing a competent and impartial legal guardian, as essential means to address their particular vulnerabilities and discrimination, protect them from all forms of violence, and provide access to sustainable solutions that are in their best interests.'

127 R. Farrugia en K. Touzenis, 'The international protection of unaccompanied and separated migrant and asylum-seeking children in Europe', in J. Kanics, D.S. Hernandez en K. Touzenis (red.), Migrating alone- Unaccompanied and separated children's migration to Europe, Unesco Publishing, 2010, 34.

128 J. Allsopp en E. Chase, 'Best Interests, Durable Solutions and Belonging: Policy Discourses Shaping the Futures of Unaccompanied Migrant and Refugee Minors Coming of Age in Europe', Journal of Ethnic and Migration Studies 45(2), 2019, 296; N. Mole en C. Meredith, Asylum and the European Convention on Human Rights, Straatsburg, Council of Europe Publishing, 2010, 187; UN Committee on the Rights of the Child, General Comment No. 6 (2005): Treatment of Unaccompanied and Separated Children Outside Their Country of Origin, CRC/GC/2005/6.

129 N. Ando, 'General Comments/Recommendations', in encyclopedie Oxford Public International Law, Oxford: Oxford University Press 2008.

130 In het dualistisch systeem moet een verdrag afzonderlijk in nationale wetgeving worden opgenomen opdat een individu zich erop kan beroepen. Het monistisch systeem vereist géén afzonderlijke opname van het verdrag in de nationale rechtsorde. Het verdrag volstaat, mits de vervulling van de nodige volkenrechtelijke en grondwettelijke voorwaarden zoals een bekrachtiging of toetreding. Zie: M. Bossuyt, 'De inroepbaarheid van verdragsbepalingen of wat is er rechtstreeks aan de rechtstreekse werking?', in J. Wouters en D. Van Eeckhoutte (red.), Doorwerking van internationaal recht in de Belgische rechtsorde, Antwerpen: Intersentia 2006, 113; J. Fleuren, 'De historische ontwikkeling van de verhouding tussen internationaal recht en nationaal recht', Ars Aequi 61, 2012, 510; J. Wouters, C. Ryngaert, T. Ruys, en G. De Baere, International Law - A European Perspective, Oxford: Hart 2019, 177-178.

131 Dit houdt klassiek (als dusdanig vorm gegeven door het HvJ) in dat het verdrag 1) geïncorporeerd is in de nationale rechtsorde en 2) de verdragsbepaling voldoende duidelijk en volledig is geformuleerd, zodanig dat de rechter de toepassing ervan kan verzekeren zonder dat verdere vervollediging of precisering door de nationale wetgever nodig is. Zie: HvJ 5 februari 1963, C26/62, ECLI:EU:C:1963:1, Van Gend \& Loos; M. Bossuyt, 'De inroepbaarheid van verdragsbepalingen of wat is er rechtstreeks aan de rechtstreekse werking?', in J. Wouters en D. Van Eeckhoutte (red.), Doorwerking van internationaal recht in de Belgische rechtsorde, Antwerpen: Intersentia 2006, 113; N. Cambien en M. Van Nieuwenborgh, 'De EU-rechtsorde: de beginselen van voorrang en rechtstreekse werking', in J. Nowak en N. Cariat (red.), Le droit de l'Union européenne et le juge belge / Het recht van de Europese Unie en de Belgische rechter, Brussel: Larcier, 2015, 73; M. Bossuyt, 'De inroepbaarheid van verdragsbepalingen of wat is er rechtstreeks aan de rechtstreekse werking?', in J. Wouters en D. Van Eeckhoutte (red.), Doorwerking van internationaal recht in de Belgische rechtsorde, Antwerpen: Intersentia 2006, 113.

132 G. Cardol, Ontheemd, vreemd en minderjarig - Het recht op ontwikkeling van de alleenstaande minderjarige vreemdeling in (inter)nationale wet- en regelgeving, Nijmegen: Wolf Legal Publishers 2005, 109. 
133 M. Reneman, 'Het Kinderrechtenverdrag krijgt tanden', $A \& M R$ 8, 2011, 361; J. Wouters, C. Ryngaert, T. Ruys, en G. De Baere, International Law - A European Perspective, Oxford: Hart 2019, 184.

134 Het Hof van Cassatie aanvaardde bijvoorbeeld de rechtstreekse werking van art. 9 lid 2 en art. 16, maar niet van onder andere art. 3, 4 en 7. Nochtans leek het Hof er oorspronkelijk van uit te gaan dat alle bepalingen rechtstreekse werking hadden. Zie ook: Belgisch Hof van Cassatie 4 november 1999, C.99.0111.N, Van Hauwermeiren/Van Damme e.a; Belgisch Hof van Cassatie 26 mei 2008, S.06.0105.F, D.D., A.S/H.D.P. Caisse de Compensation pour allocations familiales; Belgisch Hof van Cassatie 11 juni 2010, C.09.0236.F, W.N./D. M.-J; Belgische Raad van State 30 maart 2005, 142.729; Belgische Raad van State 29 mei 2013, 223.630; J. Put, Handboek Jeugdbeschermingsrecht, Brugge: Die Keure 2015, 69; W. Vandenhole, 'Belgium - The Convention of the Rights of the Child in Belgian Case Law', in T. Liefaard en J.E. Doek (red.), Litigating the Rights of the Child, Dordrecht, Springer, 2014, 106-111.

135 Nederlandse Centrale Raad van Beroep 24 januari 2006, 05/3621; Nederlandse Raad van State 22 februari 2006, 200507814/1; M. Limbeek en M. Bruning, 'The Netherlands - Two Decades of the CRC in Dutch Case Law', in T. Liefaard en J.E. Doek (red.), Litigating the Rights of the Child, Dordrecht, Springer, 2014, 265; C. van Os, 'De relevantie van het Kinderrechtenverdrag voor minderjarige vreemdelingen', Justitiële Verkenningen 38(6), 2012, 69.

136 Franse Cour de Cassation 1 oktober 2005, 1810, X/Y; J. Wouters, C. Ryngaert, T. Ruys, en G. De Baere, International Law A European Perspective, Oxford: Hart 2019, 184.

137 D. Vanheule, 'Het Global Compact for Safe, Orderly and Regular Migration', $R W$ 82(25), 2019, 962.

138 J.Y. Carlier en S. Sarolea, Droit des étrangers, Brussel: Larcier 2016, 528.

139 Qua soft law zijn bijvoorbeeld het Actieplan van de Europese Commissie (2012-2014) en de Communicatie van de Europese Commissie naar het Europees Parlement en de Raad (2016) noemenswaardig. Zie: Europese Commissie, Actieplan EU nietbegeleide minderjarigen (2010-2014), https://www.rijksoverheid.nl/documenten/richtlijnen/2011/o7/o7/actieplan-eu-nietbegeleide-minderjarigen-2010-2014; Europese Commissie, Communicatie naar het Europees Parlement en de Raad, Towards a Reform of The Common European Asylum System and Enhancing Legal Avenues to Europe, 6 april 2016, COM(2016) 197 final; J.Y. Carlier en S. Sarolea, Droit des étrangers, Brussel: Larcier 2016, 528.

140 Handvest van de Grondrechten van de Europese Unie, 18 december 2000, 2000/C 364/o1.

141 Art. 51 lid 1 Handvest van de Grondrechten van de Europese Unie; HvJ 26 februari 2013, C-617/10, ECLI:EU:C:2013:105, Aklagaren/Hans Åkerberg Fransson, §28; HvJ 10 juli 2014, C-198/13, ECLI:EU:C:2014:2055, Julian Hernandez en anderen, §3437; HvJ 9 maart 2017, C-406/15, ECLI:EU:C:2017:198, Milkova, §50-54.

142 Dit staat niet als dusdanig in het Handvest neergeschreven, maar kan worden afgeleid uit de tekst en de context van het Handvest. Zie: S. Peers, V. Moreno-Lax, M. Garlick en E. Guild, EU Immigration and Asylum Law (Text and Commentary): Second Revised Edition, Leiden: Brill Nijhoff 2015, 37.

143 Art. 18 van het Handvest stelt: 'Het recht op asiel is gegarandeerd met inachtneming van de voorschriften van het Verdrag van Genève van 28 juli 1951 en het Protocol van 31 januari 1967 betreffende de status van vluchtelingen, en overeenkomstig het Verdrag betreffende de Europese Unie en het Verdrag betreffende de werking van de Europese Unie (hierna 'de Verdragen' genoemd).'

144 S.F. Nicolosi, 'Going unnoticed? Diagnosing the right to asylum in the Charter of Fundamental Rights of the European Union', European Law Journal 23 (1-2), $2017,94$.

145 Het is dus naast op alle EU-lidstaten ook van toepassing op bijvoorbeeld Moldavië en Rusland. Zie: Chart of Signatures and Ratifications of Treaty 005 (Convention for the Protection of Human Rights and Fundamental Freedoms), https://www.coe.int/en/web/conventions/full-list/-/conventions/treaty/o05/signatures?p_auth=h42ZKciw; J. Wouters, C. Ryngaert, T. Ruys, en G. De Baere, International Law - A European Perspective, Oxford: Hart 2019, 729.

146 HvJ 18 december 2014, Advies 2/13, ECLI:EU:C:2014:2454, Advies krachtens art. 218 lid 11 VWEU (Toetreding EU tot het EVRM), §258.

147 EHRM 11 november 1996, nr. 17862/91, Cantoni/Frankrijk, §30; EHRM 18 februari 1999, nr. 24833/94, Matthews/Verenigd Koninkrijk, §33; EHRM 30 juni 2005, nr. 45036/98, Bosphorus Hava Yollari Turizm Ve Ticaret Anonim Sirketi (Bosphorus Airways)/Ierland, §165.

148 J. Lenart, 'Fortress Europe': compliance of the Dublin II regulation with the European Convention for the Protection of Human Rights and Fundamental Freedoms', Utrecht Journal of International and European Law 28(75), 2012, 8; S. Sarolea, Droits de l'homme et migrations: de la protection au migrant aux droits de la personne migrante, Brussel: Bruylant $2006,155$.

149 G. Cardol, Ontheemd, vreemd en minderjarig - Het recht op ontwikkeling van de alleenstaande minderjarige vreemdeling in (inter)nationale wet- en regelgeving, Nijmegen: Wolf Legal Publishers 2005, 197.

150 Italiaanse Grondwettelijk Hof 24 oktober 2007, 348, 6; R. Etinski en S. Dajic, 'Direct Effect of the European Convention on Human Rights', Belgrade Law review LXIII(3), 2015, 104-105.

151 J.Y. Carlier en S. Sarolea, Droit des étrangers, Brussel: Larcier 2016, 530.

152 HvJ 5 februari 1963, C-26/62, ECLI:EU:C:1963:1, Van Gend \& Loos; J. Wouters, C. Ryngaert, T. Ruys, en G. De Baere, International Law - A European Perspective, Oxford: Hart 2019, 191.

153 Gelet op de rechtstreekse toepasselijkheid van verordeningen heeft het HvJ geoordeeld dat verordeningen rechtstreekse werking hebben als aan de klassieke voorwaarden voldaan is. Een richtlijn heeft in principe pas rechtstreekse werking wanneer 
aan deze voorwaarden voldaan is en wanneer de periode voor de omzetting van de richtlijn verstreken is en de betrokken lidstaat ze niet correct heeft omgezet. Met name houdt rechtstreekse werking in de EU in dat het verdrag 1) geïncorporeerd is in de nationale rechtsorde en 2) de verdragsbepaling voldoende duidelijk en volledig is geformuleerd, zodanig dat de rechter de toepassing ervan kan verzekeren zonder dat verdere vervollediging of precisering door de nationale wetgever nodig is. Zie: art. 288 lid 3 VWEU; HvJ 17 mei 1972, C-93/71, ECLI:EU:C:1972:39, Leonesio, §22; HvJ 5 april 1979, C-148/78,

ECLI:EU:C:1979:110, Ratti, §43-44; N. Cambien en M. Van Nieuwenborgh, 'De EU-rechtsorde: de beginselen van voorrang en rechtstreekse werking', in J. Nowak en N. Cariat (red.), Le droit de l'Union européenne et le juge belge / Het recht van de Europese Unie en de Belgische rechter, Brussel: Larcier 2015, 75.

154 Art. 1 lid 1 Folterverdrag: 'Voor de toepassing van dit Verdrag wordt onder "foltering” verstaan iedere handeling waardoor opzettelijk hevige pijn of hevig leed, lichamelijk dan wel geestelijk, wordt toegebracht aan een persoon met zulke oogmerken als om van hem of van een derde inlichtingen of een bekentenis te verkrijgen, hem te bestraffen voor een handeling die hij of een derde heeft begaan of waarvan hij of een derde wordt verdacht deze te hebben begaan, of hem of een derde te intimideren of ergens toe te dwingen dan wel om enigerlei reden gebaseerd op discriminatie van welke aard ook, wanneer zulke pijn of zulk leed wordt toegebracht door of op aanstichten van dan wel met de instemming of gedogen van een overheidsfunctionaris of andere persoon die in een officiële hoedanigheid handelt. Foltering omvat niet pijn of leed slechts voortvloeiend uit, inherent aan of samenhangend met wettige straffen.'

155 EHRM 25 april 1978, nr. 5856/72, Tyrer/Verenigd Koninkrijk, §31; EHRM 15 november 1996, nr. 22414/93, Chahal/Verenigd Koninkrijk, §79-80; EHRM 17 december 1996, nr. 25964, Ahmed/Oostenrijk, §41; EHRM 12 oktober 2006, nr. 13178/o3, Mubilanzila Mayeka en Kaniki Mitunga/België, §48; EHRM 28 februari 2008, nr. 37201/o6, Saadi/Italië, §124-127; EHRM 1 juni 2010, nr. 22978/o5, Gäfgen/Duitsland, §107; B. Vermeulen en H. Battjes, 'Prohibition of Torture and Other Inhuman or Degrading Treatment or Punishment', in P. van Dijk, F. van Hoof, A. van Rijn en L. Zwaak (red.), Theory and Practice of the European Convention on Human Rights, Antwerpen: Intersentia 2018, 383.

156 Het werd in 1987 gesloten tussen de 20 landen die op dat moment lid waren van de Raad van Europa. Zie: Europees Verdrag ter voorkoming van Foltering en Onmenselijke of Vernederende Behandeling of Bestraffing van 26 november 1987.

157 EHRM 2 mei 1997, nr. 146/1996/767/964, D./Verenigd Koninkrijk, §49; K. Greenman, 'A Castle Built on Sand? Article 3 ECHR and the Source of Risk in Non-Refoulement Obligations in International Law', International Journal of Refugee Law $27(2), 2015,276$.

158 Art. 33 Vluchtelingenverdrag: '(1) Geen der Verdragsluitende Staten zal, op welke wijze ook, een vluchteling uitzetten of terugleiden naar de grenzen van een grondgebied waar zijn leven of vrijheid bedreigd zou worden op grond van zijn ras, godsdienst, nationaliteit, het behoren tot een bepaalde sociale groep of zijn politieke overtuiging. (2) Op de voordelen van deze bepaling kan evenwel geen aanspraak worden gemaakt door een vluchteling ten aanzien van wie er ernstige redenen bestaan hem te beschouwen als een gevaar voor de veiligheid van het land waar hij zich bevindt, of die, bij gewijsde veroordeeld wegens een bijzonder ernstig misdrijf, een gevaar oplevert voor de gemeenschap van dat land'. Zie: P. Boeles, M. den Heijer, G. Lodder, en K. Wouters, European Migration Law, Antwerpen: Intersentia 2014, 244.

159 G. Cardol, Ontheemd, vreemd en minderjarig - Het recht op ontwikkeling van de alleenstaande minderjarige vreemdeling in (inter)nationale wet- en regelgeving, Nijmegen: Wolf Legal Publishers 2005, 133.

16o Art. 33.2 Vluchtelingenverdrag; De UNHCR verwoordde dit als volgt: 'the exception provided for in Article 33(2) should be applied with the greatest caution. It is necessary to take fully into account all the circumstances of the case (...)'. Zie: UN High Commissioner for Refugees (UNHCR), Note on Non-Refoulement (Submitted by the High Commissioner), 23 augustus 1997, http://www.unhcr.org/excom/scip/3ae68ccd10/note-non-refoulement-submitted-high-commissioner.html, 14.

161 Art. 19 Handvest: '(1) Collectieve uitzetting is verboden. (2) Niemand mag worden verwijderd of uitgezet naar dan wel uitgeleverd aan een staat waarin een ernstig risico bestaat dat hij aan de doodstraf, aan folteringen of aan andere onmenselijke of vernederende behandelingen of bestraffingen wordt onderworpen;'. Art. 4 Handvest neemt letterlijk art. 3 EVRM over: 'Niemand mag worden onderworpen aan folteringen of aan onmenselijke of vernederende behandelingen of bestraffingen.' Zie: B.

Vermeulen en H. Battjes, 'Prohibition of Torture and Other Inhuman or Degrading Treatment or Punishment', in P. van Dijk, F. van Hoof, A. van Rijn en L. Zwaak (red.), Theory and Practice of the European Convention on Human Rights, Antwerpen: Intersentia 2018, 381 .

162 EHRM 7 juli 1989, nr. 14038/88, Soering/Verenigd Koninkrijk, §91; EHRM 20 maart 1991, nr. 15576/89, Cruz Varas e.a./Zweden, §70; EHRM 30 oktober 1991, nrs. 13163/87, 13164/87, 13165/87, 13447/87, 13448/87, Vilvarajah e.a./Verenigd Koninkrijk, §103; EHRM 15 november 1996, nr. 22414/93, Chahal/Verenigd Koninkrijk, §74; EHRM 29 april 1997, nr. 24573/94, H.L.R./Frankrijk, §44; EHRM 11 juli 2000, nr. 40035/98, Jabari/Turkije, §42; K. Greenman, 'A Castle Built on Sand? Article 3 ECHR and the Source of Risk in Non-Refoulement Obligations in International Law', International Journal of Refugee Law 27(2), 2015, 266.

163 Zo bijvoorbeeld de recente moord op de negenjarige Daniel C. in een asielcentrum. Zie: D. Baert, '9-Jarig Palestijns jongetje dood gevonden in asielcentrum van Broechem, vijf verdachten opgepakt', VRT NWS, 24 april 2019,

https://www.vrt.be/vrtnws/nl/2019/04/24/jongetje-dood-gevonden-in-asielcentrum-in-broechem-vijf-asielz/; T. Liefaard, Deprivation of Liberty of Children in Light of International Human Rights Law and Standards, Antwerpen: Intersentia 2008, 39 .

164 Deze zijn echter niet bindend, waardoor de implementatie van de regels lang gebrekkig bleef. Zie: T. Liefaard, Deprivation of Liberty of Children in Light of International Human Rights Law and Standards, Antwerpen: Intersentia 2008, 40.

165 Art. 5 lid 1 EVRM; R. Clayton, en H. Tomlinson, The Law of Human Rights, Oxford: Oxford University Press 2009, 626; T. Liefaard, Deprivation of Liberty of Children in Light of International Human Rights Law and Standards, Antwerpen: Intersentia 2008, 149; W.A. Schabas, The European Convention on Human Rights, Oxford: Oxford University Press $2015,229$.

166 EHRM 18 december 1986, nr. 9990/82, Bozano/Frankrijk, §54; EHRM 25 mei 1998, nr. 15/1997/799/1002, Kurt/Turkije, §122-123; EHRM 18 juni 2002, nr. 25656/94, Orhan/Turkije, §367; R. Clayton, en H. Tomlinson, The Law of Human Rights, 
Oxford: Oxford University Press 2009, 574; B. Rainey, E. Wicks en C. Ovey, The European Convention on Human Rights, Oxford: Oxford University Press 2017, 236; W.A. Schabas, The European Convention on Human Rights, Oxford: Oxford University Press 2015, 232-233.

167 EHRM 16 mei 2002, nr. 39474/98, D.G./Ierland, §84; EHRM 5 juli 2017, nr. 9912/15, O.M./Hongarije, §42-43; R. Clayton, en H. Tomlinson, The Law of Human Rights, Oxford: Oxford University Press 2009, 643.

168 E. Bleichrodt, 'Right to Liberty and Security', in P. van Dijk, F. van Hoof, A. van Rijn en L. Zwaak (red.), Theory and Practice of the European Convention on Human Rights, Antwerpen: Intersentia 2018, 439.

169 Art. 8 en 9 Internationaal Verdrag inzake de Burgerrechten en Politieke Rechten van 16 december 1966; C. Smyth, 'Is the right of the child to liberty safeguarded in the common European Asylum System?', European Journal of Migration and Law 15, 2013,113 .

170 Het EHRM verduidelijkt echter sinds Golder dat dit principe ook geldt voor het EVRM. Zie ook: EHRM 21 februari 1975, nr. 4451/70, Golder/Verenigd Koninkrijk, §41; T. Liefaard, Deprivation of Liberty of Children in Light of International Human Rights Law and Standards, Antwerpen: Intersentia 2008, 41.

171 C. van Os, 'De relevantie van het Kinderrechtenverdrag voor minderjarige vreemdelingen', Justitiële Verkenningen 38(6), 2012,80 .

172 Art. 37 lid b Kinderrechtenverdrag.

173 C. Smyth, 'Is the right of the child to liberty safeguarded in the common European Asylum System?', European Journal of Migration and Law 15, 2013, 114; C. van Os, 'De relevantie van het Kinderrechtenverdrag voor minderjarige vreemdelingen', Justitiële Verkenningen 38(6), 2012, 71.

174 EHRM 12 juli 2016, nr. 11593/12, A.B. e.a./Frankrijk, §124; EHRM 12 juli 2016, nr. 33201/11, R.M. e.a./Frankrijk, §91; EHRM 12 juli 2016, nr. 68264/14, R.K. e.a./Frankrijk, §86; EHRM 12 juli 2016, nr. 76491/14, R.C. en V.C./Frankrijk, §63; B. Rainey, E. Wicks en C. Ovey, The European Convention on Human Rights, Oxford: Oxford University Press 2017, 267; M. Reneman, 'Het Kinderrechtenverdrag krijgt tanden', $A \& M R$ 8, 2011, 361.

175 Art. 37 lid c Kinderrechtenverdrag; U. Brandl, en P. Czech, 'General and Specific Vulnerability of Protection-Seekers in the EU: Is there an Adequate Response to their Needs?’, in F. Ippolito en S. Iglesias (red.), Protecting Vulnerable Groups: The European Human Rights Framework, Oxford: Hart Publishing 2015, 255; C. Smyth, 'Is the right of the child to liberty safeguarded in the common European Asylum System?', European Journal of Migration and Law 15, 2013, 124.

176 Art. 37 lid d Kinderrechtenverdrag; C. Smyth, 'Is the right of the child to liberty safeguarded in the common European Asylum System?', European Journal of Migration and Law 15, 2013, 125.

177 Bijvoorbeeld: EHRM 28 oktober 2010, nr. 41533/o8, Bubullima/Griekenland; EHRM 5 april 2011, nr. 8687/o8, Rahimi/Griekenland; EHRM 24 oktober 2013, nr. 71825/11, Housein/Griekenland; EHRM 11 december 2014, nr. 70586/11, Mohamad/Griekenland; EHRM 2 april 2015, nr. 39766/o9, Aarabi/Griekenland; EHRM 24 maart 2016, nr. 14165/16, Sh.D. en anderen/Griekenland.

178 EHRM 5 april 2011, nr. 8687/o8, Rahimi/Griekenland, §110; EHRM 11 december 2014, nr. 70586/11, Mohamad/Griekenland, §86.

179 EHRM 11 december 2014, nr. 70586/11, Mohamad/Griekenland, §86.

180 Art. 3 Kinderrechtenverdrag: '(1) Bij alle maatregelen betreffende kinderen, ongeacht of deze worden genomen door openbare of particuliere instellingen voor maatschappelijk welzijn of door rechterlijke instanties, bestuurlijke autoriteiten of wetgevende lichamen, vormen de belangen van het kind de eerste overweging. (2) De Staten die partij zijn, verbinden zich ertoe het kind te verzekeren van de bescherming en de zorg die nodig zijn voor zijn of haar welzijn, rekening houdend met de rechten en plichten van zijn of haar ouders, wettige voogden of anderen die wettelijk verantwoordelijk voor het kind zijn, en nemen hiertoe alle passende wettelijke en bestuur maatregelen. (3) De Staten die partij zijn, waarborgen dat de instellingen, diensten en voorzieningen die verantwoordelijk zijn voor de zorg voor of de bescherming van kinderen voldoen aan de door de bevoegde autoriteiten vastgestelde normen, met name ten aanzien van de veiligheid, de gezondheid, het aantal personeelsleden en hun geschiktheid, alsmede bevoegd toezicht.'

181 EHRM 23 juni 2008, nr. 1638/o3, Maslov/Oostenrijk, §82-83; N.E. Nguema, 'La protection des mineurs migrants nonaccompagnés en Europe', Revue du Centre de recherches et d'études sur les droits fondamentaux 7, 2015, 9.

182 Art. 24 Handvest van de Grondrechten van de Europese Unie; M. Kalverboer, D. Beltman, C. van Os, en E. Zijlstra, 'The Best Interests of the Child in Cases of Migration: Assessing and Determining the Best Interests of the Child in Migration', International Journal of Children's Rights 25, 2017, 115.

183 M. Blaak, M. Bruning, M. Eijgenraam, M. Kaandorp en S. Meuwese, 'De Rechten van het Kind', in M. Blaak, M. Bruning, M. Eijgenraam, M. Kaandorp en S. Meuwese (red.), Handboek Internationaal Jeugdrecht, Leiden: Defence for Children 2012, 166.

$\mathbf{1 8 4}$ Zo kunnen landen bijvoorbeeld culturele overwegingen laten meespelen bij hun normatieve invulling van het begrip. Zie: J. Allsopp en E. Chase, 'Best Interests, Durable Solutions and Belonging: Policy Discourses Shaping the Futures of Unaccompanied Migrant and Refugee Minors Coming of Age in Europe', Journal of Ethnic and Migration Studies 45(2), 2019, 297; T. Buck, International Child Law, Londen: Routledge 2014, 137.

185 UN Committee on the Rights of the Child, General Comment No. 14 (2013): The Right of the Child to have his or her Best Interest Taken as a Primary Consideration, CRC/C/GC/14; N.E. Nguema, 'La protection des mineurs migrants nonaccompagnés en Europe', Revue du Centre de recherches et d'études sur les droits fondamentaux 7, 2015, 10. 
186 UN Committee on the Rights of the Child, General Comment No. 14 (2013): The Right of the Child to have his or her Best Interest Taken as a Primary Consideration, $\mathrm{CRC} / \mathrm{C} / \mathrm{GC} / 14,9$.

187 J. Allsopp en E. Chase, 'Best Interests, Durable Solutions and Belonging: Policy Discourses Shaping the Futures of Unaccompanied Migrant and Refugee Minors Coming of Age in Europe', Journal of Ethnic and Migration Studies 45(2), 2019, 297; N.E. Nguema, 'La protection des mineurs migrants non-accompagnés en Europe', Revue du Centre de recherches et d'études sur les droits fondamentaux 7, 2015, 9.

188 K. De Graeve, 'Classed Landscapes of Care and Belonging: Guardianships of Unaccompanied Minors', Journal of Refugee Studies 30(1), 2015, 73; C. Gimeno-Monterde en J.D. Guttierez-Sanchez, 'Fostering Unaccompanied Migrating Minors: A Crossborder Comparison', Children and Youth Services Review 99, 2019, 41.

189 M. Blaak, M. Bruning, M. Eijgenraam, M. Kaandorp en S. Meuwese, 'De Rechten van het Kind', in M. Blaak, M. Bruning, M. Eijgenraam, M. Kaandorp en S. Meuwese (red.), Handboek Internationaal Jeugdrecht, Leiden: Defence for Children $2012,167$.

190 M. Kalverboer, D. Beltman, C. van Os, en E. Zijlstra, 'The Best Interests of the Child in Cases of Migration: Assessing and Determining the Best Interests of the Child in Migration', International Journal of Children's Rights 25, 2017, 116.

191 Ibidem.

192 Dit artikel is, volgens de Toelichtingen bij het Handvest, rechtstreeks gebaseerd op art. 3 van het Kinderrechtenverdrag. Zie: art. 24 lid 2 van het Handvest: 'Bij alle handelingen in verband met kinderen, ongeacht of deze worden verricht door overheidsinstanties of particuliere instellingen, vormen de belangen van het kind een essentiële overweging.'; Toelichtingen bij het Handvest van de Grondrechten, 14 december 2007, 2007/C 303/o2; M. Kalverboer, D. Beltman, C. van Os, en E. Zijlstra, 'The Best Interests of the Child in Cases of Migration: Assessing and Determining the Best Interests of the Child in Migration', International Journal of Children's Rights 25, 2017, 118.

193 Europese Commissie, Voorstel voor een richtlijn van het Europees Parlement en de Raad, tot vaststelling van normen voor de opvang van verzoekers om internationale bescherming (herschikking), 13 juli 2016, COM(2016) 465 final (Voorstel Richtlijn Opvangvoorzieningen); Europese Commissie, Voorstel voor een verordening van het Europees Parlement en de Raad tot vaststelling van een gemeenschappelijke procedure voor internationale bescherming in de Unie en tot intrekking van Richtlijn 2013/32/EU, 13 juli 2016, COM(2016) 467 final (Voorstel Procedureverordening).

194 Richtlijn 2013/33/EU van de Raad van 26 juni 2013, tot vaststelling van normen voor de opvang van verzoekers om internationale bescherming (herschikking).

195 R. Farrugia en K. Touzenis, 'The international protection of unaccompanied and separated migrant and asylum-seeking children in Europe', in J. Kanics, D.S. Hernandez en K. Touzenis (red.), Migrating alone- Unaccompanied and separated children's migration to Europe, Unesco Publishing, 2010, 39.

196 Vluchtelingenwerk Vlaanderen, Wat is Dublin?, 19 oktober 2013, https://www.vluchtelingenwerk.be/sites/default/files/watis-dublin_v04-201602-distribution.pdf, 5 .

197 Europees Parlement, Briefing: Reform of the Dublin System, 1 maart 2019,

http://www.europarl.europa.eu/RegData/etudes/BRIE/2016/586639/EPRS_BRI\%282016\%29586639_EN.pdf;

Vluchtelingenwerk Vlaanderen, Wat is Dublin?, 19 oktober 2013, https://www.vluchtelingenwerk.be/sites/default/files/wat-isdublin_v04-201602-distribution.pdf, 7 .

198 ECRE, Comments on the Commission Proposal for a Dublin IV Regulation (Com(2016) 270), oktober 2016, 4; C. Costello, The Human Rights of Migrants and Refugees in European Law, Oxford: Oxford University Press 2016, 255; F. Cherubini, Asylum Law in the European Union, Londen: Routledge 2015, 243; K. Pollet, 'Grondrechtenbescherming in de Dublin IIIverordening: de doodsteek voor het Dublinsysteem?', in D. Vanheule (red.), Migratie en migrantenrecht - ontwikkelingen inzake arbeidsdiscriminatie, detachering van werknemers, kinderontvoering en de Dublinverordening, Brugge: Die Keure 2017, 125; J. Wouters, C. Ryngaert, T. Ruys, en G. De Baere, International Law - A European Perspective, Oxford: Hart 2019, 695.

199 Europees Parlement, Briefing: Reform of the Dublin System, 1 maart 2019,

http://www.europarl.europa.eu/RegData/etudes/BRIE/2016/586639/EPRS_BRI\%282016\%29586639_EN.pdf;

Vluchtelingenwerk Vlaanderen, Wat is Dublin?, 19 oktober 2013, https://www.vluchtelingenwerk.be/sites/default/files/wat-isdublin_v04-201602-distribution.pdf, 7 .

\section{Ibidem.}

201 Besluit 2006/18/EG van de Raad van 21 februari 2006 betreffende de sluiting van de Overeenkomst tussen de Europese Gemeenschap en het Koninkrijk Denemarken houdende uitbreiding tot Denemarken van de bepalingen van Verordening (EG) nr. $343 / 2003$ van de Raad tot vaststelling van de criteria en instrumenten om te bepalen welke lidstaat verantwoordelijk is voor de behandeling van een asielverzoek dat door een onderdaan van een derde land bij een van de lidstaten wordt ingediend en van Verordening (EG) nr. 2725/2000 van de Raad betreffende de instelling van 'Eurodac' voor de vergelijking van vingerafdrukken ten behoeve van een doeltreffende toepassing van de Overeenkomst van Dublin.

202 Zie respectievelijk: Besluit 2001/258/EG van de Raad van 15 maart 2001 inzake de sluiting van een overeenkomst tussen de Europese Gemeenschap, de Republiek IJsland en het Koninkrijk Noorwegen betreffende de criteria en mechanismen voor de vaststelling van de staat die verantwoordelijk is voor de behandeling van een asielverzoek dat in een lidstaat, in IJsland of in Noorwegen wordt ingediend; Besluit 2008/147/EG van de Raad van 28 januari 2008 betreffende de sluiting namens de Europese Gemeenschap van de Overeenkomst tussen de Europese Gemeenschap en de Zwitserse Bondsstaat inzake de criteria en mechanismen voor de vaststelling van de staat die verantwoordelijk is voor de behandeling van een asielverzoek dat in een lidstaat of in Zwitserland wordt ingediend; Besluit 2011/351/EU van de Raad van 7 maart 2011 betreffende de sluiting van een Protocol tussen de Europese Gemeenschap, de Zwitserse Bondsstaat en het Vorstendom Liechtenstein betreffende de toetreding van het Vorstendom Liechtenstein tot de Overeenkomst tussen de Europese Gemeenschap en de Zwitserse Bondsstaat inzake de 
criteria en mechanismen voor de vaststelling van de staat die verantwoordelijk is voor de behandeling van een asielverzoek dat in een lidstaat of in Zwitserland wordt ingediend; S. Peers, V. Moreno-Lax, M. Garlick en E. Guild, EU Immigration and Asylum Law (Text and Commentary): Second Revised Edition, Leiden: Brill Nijhoff 2015, 345-346.

203 Het Stockholmprogramma is een opvolger van het programma van Tampere. Tampere stippelde een beleid voor Justitie en Binnenlandse Zaken van de EU uit voor 2005-2009, het Stockholmprogramma deed dit voor 2009-2014. Zie: Europese Raad, Het Programma van Stockholm - Een open en veilig Europa ten dienste en ter bescherming van de burger, 4 mei 2010, 2010/C 115/01, titel 6.2.1.; Liga voor de Mensenrechten, 'The Stockholm Program', 29 oktober 2009,

https://mensenrechten.be/nieuwsberichten/the_stockholm_program.

204 S. Peers, V. Moreno-Lax, M. Garlick en E. Guild, EU Immigration and Asylum Law (Text and Commentary): Second Revised Edition, Leiden: Brill Nijhoff 2015, 345; K. Pollet, 'Grondrechtenbescherming in de Dublin III-verordening: de doodsteek voor het Dublinsysteem?', in D. Vanheule (red.), Migratie en migrantenrecht - ontwikkelingen inzake arbeidsdiscriminatie, detachering van werknemers, kinderontvoering en de Dublinverordening, Brugge: Die Keure 2017, 125.

205 Art. 13 lid 1 Dublin III-verordening; P. Biondi, 'Compliance with Fundamental Rights Demands Shared Responsibility', in V. Stoyanova en E. Karageorgiou (red.), The New Asylum and Transit Countries in Europe during and in the Aftermath of the 2015/2016 Crisis, Leiden: Brill Nijhoff 2019, 264.

206 P. Biondi, 'Compliance with Fundamental Rights Demands Shared Responsibility', in V. Stoyanova en E. Karageorgiou (red.), The New Asylum and Transit Countries in Europe during and in the Aftermath of the 2015/2016 Crisis, Leiden: Brill Nijhoff 2019, 263-264.

207 Art. 35 Dublin IV-voorstel; Europees Parlement, Briefing: Reform of the Dublin System, 1 maart 2019, http://www.europarl.europa.eu/RegData/etudes/BRIE/2016/586639/EPRS_BRI\%282016\%29586639_EN.pdf.

208 Art. 34(2) Dublin IV-voorstel; Europees Parlement, Briefing: Reform of the Dublin System, 1 maart 2019, http://www.europarl.europa.eu/RegData/etudes/BRIE/2016/586639/EPRS_BRI\%282016\%29586639_EN.pdf; Onderzoeksdienst van het Europees Parlement (EPRS), Reform of the Dublin System, 1 maart 2019, PE 586.639.

209 Art. 37(2-3) Dublin IV-voorstel; Onderzoeksdienst van het Europees Parlement (EPRS), Reform of the Dublin System, 1 maart 2019, PE 586.639.

210 P. Boeles, M. den Heijer, G. Lodder, en K. Wouters, European Migration Law, Antwerpen: Intersentia 2014, 254.

211 Dublin IV-voorstel, p. 5 en 19.

212 R.o. 20 Dublin IV-voorstel.

213 Art. 30 e.v. Dublin IV-voorstel.

214 R.o. 2 Dublin IV-voorstel; L. Leboeuf, Le droit européen de l'asile - Au défi de la confiance mutuelle, Limal: Anthemis 2016, 233 .

215 L. Leboeuf, Le droit européen de l'asile - Au défi de la confiance mutuelle, Limal: Anthemis 2016, 233; UN High Commissioner for Refugees (UNHCR), States Parties to the Convention relating to the Status of Refugees and the 1967 Protocol, 5 p., http://www.unhcr.org/protection/basic/3b73bod63/states-parties-1951-convention-its-1967-protocol.html.

216 V. Moreno-Lax, 'Dismantling the Dublin System: M.S.S. v. Belgium and Greece', European Journal of Migration and Law 14, 2012, 5 .

217 EHRM 21 januari 2011, nr. 30696/o9, M.S.S./België en Griekenland, §264; HvJ 21 december 2011, C-411/10, ECLI:EU:C:2011:865, N.S./Secretary of State for the Home Department e.a., §94; P. Biondi, 'Compliance with Fundamental Rights Demands Shared Responsibility', in V. Stoyanova en E. Karageorgiou (red.), The New Asylum and Transit Countries in Europe during and in the Aftermath of the 2015/2016 Crisis, Leiden: Brill Nijhoff 2019, 267.

218 Bijvoorbeeld in: EHRM 12 oktober 2006, nr. 13178/o3, Mubilanzila Mayeka en Kaniki Mitunga/België, §71; EHRM 24 oktober 2013, nr. 71825/11, Housein/Griekenland, §63; EHRM 22 november 2016, nrs. 25794/13 en 28151/13, Abdullahi Elmi en Aweys Abubakar/Malta, §115.

219 EHRM 21 januari 2011, nr. 30696/o9, M.S.S./België en Griekenland, §264; M. Bossuyt, 'The European Union Confronted with an Asylum Crisis in the Mediterranean: Reflections on Refugees and Human Rights Issues', European Journal of Human Rights 5, 2015, 593 .

220 HvJ 21 december 2011, C-411/10, ECLI:EU:C:2011:865, N.S./Secretary of State for the Home Department e.a., §94; G. De Baere, 'The Court of Luxemburg acting as an asylum court', in A. Alen, V. Joosten, R. Leysen en W. Verrijdt (red.), Liberae Cogitationes: Liber Amicorum Marc Bossuyt, Antwerpen: Intersentia 2013, 114-115.

221 HvJ 21 december 2011, C-411/10, ECLI:EU:C:2011:865, N.S./Secretary of State for the Home Department e.a., §86; A. Woltjer, 'The European Court of Human Rights and the Court of Justice of the European Union: an Imperfect Match? Interaction Between both Courts in the Field of Immigration Law', in M. van Roosmalen, B. Vermeulen, F. van Hoof en M. Oosting (red.), Fundamental Rights and Principles: Liber Amicorum Pieter van Dijk, Antwerpen: Intersentia 2013, 222-223; J. Wouters, C. Ryngaert, T. Ruys, en G. De Baere, International Law - A European Perspective, Oxford: Hart 2019, 695-696.

222 Art. 3 Verordening (EU), nr. 604/2013 van de Raad van 26 juni 2013 tot vaststelling van de criteria en instrumenten om te bepalen welke lidstaat verantwoordelijk is voor de behandeling van een asielverzoek dat door een onderdaan van een derde land bij een van de lidstaten wordt ingediend (Dublin III). 
223 Reeds sinds 2016 dringt de Commissie er echter op aan om de mogelijkheid van overdrachten naar Griekenland te hervatten. In België oordeelde de Raad voor Vreemdelingenbetwistingen afgelopen zomer bijvoorbeeld voor het eerst sinds lange tijd dat Dublinoverdrachten naar Griekenland onder bepaalde voorwaarden terug mogelijk zijn. Zie: Europese Commissie, Aanbeveling gericht tot de Helleense Republiek over de door Griekenland te nemen specifieke dringende maatregelen met het oog op de hervatting van overdrachten uit hoofde van Verordening (EU) nr. 604/2013 van het Europees Parlement en de Raad, 28 september 2016, L 286/75; Agentschap Integratie en Inburgering, 'RvV bevestigt mogelijkheid tot Dublinoverdracht naar Griekenland onder bepaalde voorwaarden', 4 juli 2018, http://www.agii.be/nieuws/rvv-bevestigt-mogelijkheid-totdublinoverdracht-naar-griekenland-onder-bepaalde-voorwaarden; N. Koffeman en L. Hillary, 'Mensenrechtelijke zorgen bij de plannen voor herziening van het Gemeenschappelijk Europees Asielsysteem', NTM 43(1), 2018, 121.

224 EHRM 4 november 2014, nr. 29217/12, Tarakhel/Zwitserland.

225 In Tarakhel ging het om een gezin met zes kinderen. Zie: EHRM 4 november 2014, nr. 29217/12, Tarakhel/Zwitserland, §1.

226 EHRM 4 november 2014, nr. 29217/12, Tarakhel/Zwitserland, §104-105; M. Bossuyt, 'The European Union Confronted with an Asylum Crisis in the Mediterranean: Reflections on Refugees and Human Rights Issues', European Journal of Human Rights 5, 2015, 597; MYRIA, Migratie in cijfers en in rechten 2015, Myriadocs, 3 september 2015,

https://www.myria.be/nl/publicaties/migratie-in-cijfers-en-in-rechten-2015, 93.

227 P. Biondi, 'Compliance with Fundamental Rights Demands Shared Responsibility', in V. Stoyanova en E. Karageorgiou (red.), The New Asylum and Transit Countries in Europe during and in the Aftermath of the 2015/2016 Crisis, Leiden: Brill Nijhoff 2019, 291; N. Koffeman en L. Hillary, 'Mensenrechtelijke zorgen bij de plannen voor herziening van het Gemeenschappelijk Europees Asielsysteem', NTM 43(1), 2018, 121; L. Leboeuf, Le droit européen de l'asile - Au défi de la confiance mutuelle, Limal: Anthemis 2016, 243.

228 EHRM 4 november 2014, nr. 29217/12, Tarakhel/Zwitserland, §122.

229 Ibidem.

23o Art. 3.2. lid 2: 'Indien het niet mogelijk is een verzoeker over te dragen aan de lidstaat die in de eerste plaats als verantwoordelijke lidstaat is aangewezen, omdat ernstig moet worden gevreesd dat de asielprocedure en de opvangvoorzieningen voor verzoekers in die lidstaat systeemfouten bevatten die resulteren in onmenselijke of vernederende behandelingen in de zin van artikel 4 van het Handvest van de grondrechten van de Europese Unie, blijft de lidstaat die met het bepalen van de verantwoordelijke lidstaat is belast de criteria van hoofdstuk III onderzoeken teneinde vast te stellen of een andere lidstaat als verantwoordelijke lidstaat kan worden aangewezen.'

231 HvJ 16 februari 2017, C-578/16, ECLI:EU:C:2017:127, C.K. e.a./Republika Slovenija, §91.

232 ECRE, Comments on the Commission Proposal for a Dublin IV Regulation (Com(2016) 270), oktober 2016, 6; N. Koffeman en L. Hillary, 'Mensenrechtelijke zorgen bij de plannen voor herziening van het Gemeenschappelijk Europees Asielsysteem', NTM 43(1), 2018, 122.

233 Europees Parlement, Verslag over het voorstel voor een verordening van het Europees Parlement en de Raad tot vaststelling van de criteria en instrumenten om te bepalen welke lidstaat verantwoordelijk is voor de behandeling van een verzoek om internationale bescherming dat door een onderdaan van een derde land of een staatloze bij een van de lidstaten wordt ingediend (herschikking), 6 november 2017, A8-0345/2017, amendement 50.

234 Europees Economisch en Sociaal Comité (EESC), Advies over het voorstel voor een verordening van het Europees Parlement en de Raad tot vaststelling van de criteria en instrumenten om te bepalen welke lidstaat verantwoordelijk is voor de behandeling van een verzoek om internationale bescherming dat door een onderdaan van een derde land of een staatloze bij een van de lidstaten wordt ingediend (herschikking), 2 februari 2017, C 34/144, 4.1.

235 Onder het voorstel wordt begrepen 'gezinslid of broer of zus', het huidige - overbodige - 'of broer of zus' werd geschrapt.

236 Art. 10.3 Dublin IV-voorstel.

237 K. Pollet, 'Grondrechtenbescherming in de Dublin III-verordening: de doodsteek voor het Dublinsysteem?', in D. Vanheule (red.), Migratie en migrantenrecht - ontwikkelingen inzake arbeidsdiscriminatie, detachering van werknemers,

kinderontvoering en de Dublinverordening, Brugge: Die Keure 2017, 146.

238 Art. 1 Uitvoeringsverordening, nr. 118/2014 van de Commissie van 30 januari 2014 tot wijziging van Verordening (EG) $\mathrm{nr}$. 1560/2003 houdende uitvoeringsbepalingen van Verordening (EG) nr. 343/2003 van de Raad tot vaststelling van de criteria en instrumenten om te bepalen welke lidstaat verantwoordelijk is voor de behandeling van een asielverzoek dat door een onderdaan van een derde land bij een van de lidstaten wordt ingediend.

239 K. Pollet, 'Grondrechtenbescherming in de Dublin III-verordening: de doodsteek voor het Dublinsysteem?', in D. Vanheule (red.), Migratie en migrantenrecht - ontwikkelingen inzake arbeidsdiscriminatie, detachering van werknemers,

kinderontvoering en de Dublinverordening, Brugge: Die Keure 2017, 146.

240 Ibidem.

241 Art. 8 lid 4 Dublin III-verordening.

242 Art. 10 lid 5 Dublin IV-voorstel.

243 FRA, Opinion of the European Union Agency for Fundamental Rights on the impact of the proposal for a revised Dublin Regulation (COM(2016)270 final; 2016/o133 COD), 23 november 2016, 49. 
244 Ibidem.

245 ECRE, Comments on the Commission Proposal for a Dublin IV Regulation (Com(2016) 270), oktober 2016, 2; Europees Comité van de Regio's (CvdR), Advies rond de hervorming van het gemeenschappelijk Europees asielstelsel, 7-8 december 2016, CIVEX-VI/o13, wijzigingsvoorstel 5; Meijers Committee, Note on the proposed reforms of the Dublin Regulation (COM(2016) 197), the Eurodac recast proposal (COM(2016) 272 final) and the proposal for an EU Asylum Agency (COM(2016) 271 final), 2016, 5 .

246 HvJ 6 juni 2013, C-648/11, ECLI:EU:C:2013:367, M.A. e.a./Secretary of State for the Home Department; ECRE, Comments on the Commission Proposal for a Dublin IV Regulation (Com(2016) 27o), oktober 2016, 6 (10); FRA, Opinion of the European Union Agency for Fundamental Rights on the impact of the proposal for a revised Dublin Regulation (COM(2016)270 final; 2016/o133 COD), 23 november 2016, 48; Meijers Committee, Note on the proposed reforms of the Dublin Regulation (COM(2016) 197), the Eurodac recast proposal (COM(2016) 272 final) and the proposal for an EU Asylum Agency (COM(2016) 271 final), 2016, 5; S. Peers, 'The Second Phase of the Common European Asylum System: A Brave New World - or Lipstick on a Pig?', Statewatch Analysis, 2013, 7.

247 'Aangezien niet-begeleide minderjarigen bijzonder kwetsbare personen zijn, komt het erop aan de procedure strekkende tot vaststelling van de verantwoordelijke lidstaat niet langer te laten duren dan strikt noodzakelijk, hetgeen impliceert dat zij in beginsel niet aan een andere lidstaat worden overgedragen.' Zie: HvJ 6 juni 2013, C-648/11, ECLI:EU:C:2013:367, M.A. e.a./Secretary of State for the Home Department, $§ 55$.

248 HvJ 6 juni 2013, C-648/11, ECLI:EU:C:2013:367, M.A. e.a./Secretary of State for the Home Department, §57; Meijers Committee, Note on the proposed reforms of the Dublin Regulation (COM(2016) 197), the Eurodac recast proposal (COM(2016) 272 final) and the proposal for an EU Asylum Agency (COM(2016) 271 final), 2016, 5.

249 HvJ 6 juni 2013, C-648/11, ECLI:EU:C:2013:367, M.A. e.a./Secretary of State for the Home Department, §6o-61; FRA, Opinion of the European Union Agency for Fundamental Rights on the impact of the proposal for a revised Dublin Regulation (COM(2016)27o final; 2016/o133 COD), 23 november 2016, 49.

250 Europees Parlement, Verslag over het voorstel voor een verordening van het Europees Parlement en de Raad tot vaststelling van de criteria en instrumenten om te bepalen welke lidstaat verantwoordelijk is voor de behandeling van een verzoek om internationale bescherming dat door een onderdaan van een derde land of een staatloze bij een van de lidstaten wordt ingediend (herschikking), 6 november 2017, A8-0345/2017, amendement 10 en 110.

251 Ibidem, amendement 110.

252 Ibidem, amendement 173.

253 Art. 6 lid 2 Dublin III-verordening: 'De lidstaten zorgen ervoor dat de niet-begeleide minderjarige bij alle procedures waarin deze verordening voorziet, wordt vertegenwoordigd en/of bijgestaan door een vertegenwoordiger.'

254 Het Europees Parlement kiest voor de term 'voogd' in plaats van 'vertegenwoordiger'. Zie: art. 8 lid 2 Dublin IV-voorstel; Europees Parlement, Verslag over het voorstel voor een verordening van het Europees Parlement en de Raad tot vaststelling van de criteria en instrumenten om te bepalen welke lidstaat verantwoordelijk is voor de behandeling van een verzoek om internationale bescherming dat door een onderdaan van een derde land of een staatloze bij een van de lidstaten wordt ingediend (herschikking), 6 november 2017, A8-0345/2017, amendement 90.

255 Art. 8 lid 2 Dublin IV-voorstel; MYRIA, Migratie in cijfers en in rechten 2015, Myriadocs, 3 september 2015, https://www.myria.be/nl/publicaties/migratie-in-cijfers-en-in-rechten-2015, 92.

256 N. Koffeman en L. Hillary, 'Mensenrechtelijke zorgen bij de plannen voor herziening van het Gemeenschappelijk Europees Asielsysteem', NTM 43(1), 2018, 131.

257 ECRE, Comments on the Commission Proposal for a Dublin IV Regulation (Com(2016) 270), oktober 2016, 2; Europees Comité van de Regio's (CvdR), Advies rond de hervorming van het gemeenschappelijk Europees asielstelsel, 7-8 december 2016, CIVEX-VI/o13, wijzigingsvoorstel 4.

258 Europees Parlement, Verslag over het voorstel voor een verordening van het Europees Parlement en de Raad tot vaststelling van de criteria en instrumenten om te bepalen welke lidstaat verantwoordelijk is voor de behandeling van een verzoek om internationale bescherming dat door een onderdaan van een derde land of een staatloze bij een van de lidstaten wordt ingediend (herschikking), 6 november 2017, A8-0345/2017, amendement 90.

259 FRA, Opinion of the European Union Agency for Fundamental Rights on the impact of the proposal for a revised Dublin Regulation (COM(2016)27o final; 2016/o133 COD), 23 november 2016, 49.

260 Ibidem, 49.

261 Europees Economisch en Sociaal Comité (EESC), Advies over het voorstel voor een verordening van het Europees Parlement en de Raad tot vaststelling van de criteria en instrumenten om te bepalen welke lidstaat verantwoordelijk is voor de behandeling van een verzoek om internationale bescherming dat door een onderdaan van een derde land of een staatloze bij een van de lidstaten wordt ingediend (herschikking), 2 februari 2017, C 34/144, 4.1.

262 EHRM 4 november 2014, nr. 29217/12, Tarakhel/Zwitserland, §104; Europees Economisch en Sociaal Comité (EESC), Advies over het voorstel voor een verordening van het Europees Parlement en de Raad tot vaststelling van de criteria en instrumenten om te bepalen welke lidstaat verantwoordelijk is voor de behandeling van een verzoek om internationale bescherming dat door een onderdaan van een derde land of een staatloze bij een van de lidstaten wordt ingediend (herschikking), 2 februari 2017, C 34/144, 4.1. 
263 Europees Parlement, Verslag over het voorstel voor een verordening van het Europees Parlement en de Raad tot vaststelling van de criteria en instrumenten om te bepalen welke lidstaat verantwoordelijk is voor de behandeling van een verzoek om internationale bescherming dat door een onderdaan van een derde land of een staatloze bij een van de lidstaten wordt ingediend (herschikking), 6 november 2017, A8-0345/2017, amendement 50.

264 Europees Comité van de Regio's (CvdR), Advies rond de hervorming van het gemeenschappelijk Europees asielstelsel, 7-8 december 2016, CIVEX-VI/o13, wijzigingsvoorstel 5; Meijers Committee, Note on the proposed reforms of the Dublin Regulation (COM(2016) 197), the Eurodac recast proposal (COM(2016) 272 final) and the proposal for an EU Asylum Agency (COM(2016) 271 final), 2016, 5 .

265 Europees Parlement, Verslag over het voorstel voor een verordening van het Europees Parlement en de Raad tot vaststelling van de criteria en instrumenten om te bepalen welke lidstaat verantwoordelijk is voor de behandeling van een verzoek om internationale bescherming dat door een onderdaan van een derde land of een staatloze bij een van de lidstaten wordt ingediend (herschikking), 6 november 2017, A8-0345/2017, amendement 90.

266 N. Koffeman en L. Hillary, 'Mensenrechtelijke zorgen bij de plannen voor herziening van het Gemeenschappelijk Europees Asielsysteem', NTM 43(1), 2018, 122.

267 Art. 37 lid d Kinderrechtenverdrag.

268 Art. 9 lid 3 en 4 Voorstel Opvangrichtlijn.

269 Art. 4 lid 2 onderdeel f Voorstel Procedureverordening.

270 Art. 9 lid 4 Voorstel Opvangrichtlijn; C. Smyth, 'Is the right of the child to liberty safeguarded in the common European Asylum System?', European Journal of Migration and Law 15, 2013, 135.

271 Het EHRM interpreteert 'gearresteerd' als 'gearresteerd of gedetineerd'. Zie: EHRM 21 februari 1990, nr. 11509/85, Van Der Leer/Nederland, §27-28.

272 EHRM 30 augustus 1990, nrs. 12244/86, 12245/86, 12383/86, Fox, Campbell en Hartley/Verenigd Koninkrijk, §40; EHRM 11 oktober 2007, nr. 656/o6, Nasrulloyev/Rusland, §77; EHRM 22 september 2009, nr. 30471/o8, Abdolkhani en Karimnia/Turkije, §136; EHRM 23 juli 2013, nr. 41872/10, M.A./Cyprus, §229; EHRM 24 maart 2016, nr. 28026/o5, Sharma/Letland, §87; EHRM 15 december 2016, nr. 16483/12, Khlaifia e.a./Italië, §115; E. Bleichrodt, 'Right to Liberty and Security', in P. van Dijk, F. van Hoof, A. van Rijn en L. Zwaak (red.), Theory and Practice of the European Convention on Human Rights, Antwerpen: Intersentia 2018, 470; C. Smyth, 'Is the right of the child to liberty safeguarded in the common European Asylum System?', European Journal of Migration and Law 15, 2013, 125.

273 EHRM 8 november 2012, nr. 28973/11, Z.H./Hongarije, §41; D. Harris, M. O’Boyle, E. Bates en C. Buckley, Law of the European Convention on Human Rights, Oxford: Oxford University Press 2014, 335.

274 Art. 9 lid 4 Voorstel Opvangrichtlijn.

275 C. Smyth, 'Is the right of the child to liberty safeguarded in the common European Asylum System?', European Journal of Migration and Law 15, 2013, 125.

276 Zo was bijvoorbeeld de NBMV in Rahimi ongeletterd. Zie: EHRM 5 april 2011, nr. 8687/o8, Rahimi/Griekenland, §8.

277 EHRM 8 november 2012, nr. 28973/11, Z.H./Hongarije, §42-43.

278 Europees Parlement, Verslag over het voorstel voor een richtlijn van het Europees Parlement en de Raad tot vaststelling van normen voor de opvang van verzoekers om internationale bescherming (herschikking), 10 mei 2017, A8-0186/2017, amendementen $53-61$.

279 Art. 11 lid 3 Voorstel Opvangrichtlijn.

280 Europese Commissie, Voorstel voor een richtlijn van het Europees Parlement en de Raad, tot vaststelling van minimumnormen voor de opvang van asielzoekers in de lidstaten (herschikking), 3 december 2008, COM(2008) 815 final, 24 ; C. Smyth, 'Is the right of the child to liberty safeguarded in the common European Asylum System?', European Journal of Migration and Law 15, 2013, 132.

281 ECRE, Comments on the Commission Proposal to recast the Reception Conditions Directive (Com (2016) 465), oktober 2016, 14 .

282 EHRM 5 april 2011, nr. 8687/o8, Rahimi/Griekenland, §110; EHRM 19 april 2012, nr. 39472/o7, Popov/Frankrijk, §147; EHRM 11 december 2014, nr. 70586/11, Mohamad/Griekenland, §86; EHRM 12 juli 2016, nr. 11593/12, A.B. e.a./Frankrijk, §110 (122); J. Bhabha, 'Arendt's children: do today's migrant children have a right to have rights?', Human Rights Quarterly 31, 2009, 430.

283 UN High Commissioner for Refugees (UNHCR), Guidelines on the Applicable Criteria and Standards relating to the Detention of Asylum Seekers and Alternatives to Detention, 2012, https://www.unhcr.org/publications/legal/505b10ee9/unhcrdetention-guidelines.html, 36.

$\mathbf{2 8 4}$ C. Smyth, 'Is the right of the child to liberty safeguarded in the common European Asylum System?', European Journal of Migration and Law 15, 2013, 133.

285 Art. 37 lid b Kinderrechtenverdrag. 
286 Art. 11 lid 3 Voorstel Opvangrichtlijn.

$\mathbf{2 8} 7$ Art. 37 lid c Kinderrechtenverdrag.

288 C. Smyth, 'Is the right of the child to liberty safeguarded in the common European Asylum System?', European Journal of Migration and Law 15, 2013, 133-134.

289 De Telegraaf, 'Vluchtelingenwerk: Opvangcentra raken vol', De Telegraaf, 2 november 2018,

https://www.telegraaf.nl/nieuws/2752905/vluchtelingen-werk-opvangcentra-raken-vol; B. Struys, 'Opvangcentra zitten overvol door grotere instroom: tenten voor azielzoekers weer in beeld', De Morgen, 16 november 2018,

https://www.demorgen.be/nieuws/opvangcentra-zitten-overvol-door-grotere-instroom-tenten-voor-asielzoekers-weer-in-beeldb14afd39/.

290 Art. 11 lid 2 Voorstel Opvangrichtijn.

291 EHRM 25 juni 1996, nr. 19776/92, Amuur/Frankrijk, §49; EHRM 24 januari 2008, nrs. 29787/o3 en 29810/o3, Riad en Idiab/België, §77; G. Cardol, Ontheemd, vreemd en minderjarig - Het recht op ontwikkeling van de alleenstaande minderjarige vreemdeling in (inter)nationale wet- en regelgeving, Nijmegen: Wolf Legal Publishers 2005, 185; G. Cornelisse, 'Mensenrechten begrensd: detentie in het vreemdelingenrecht', Justitiële Verkeningen 38(6), 2012, 61.

292 ECRE, Comments on the Commission Proposal to recast the Reception Conditions Directive (Com (2016) 465), oktober 2016, 13; Europees Economisch en Sociaal Comité (EESC), Advies over het voorstel voor een richtlijn van het Europees Parlement en de Raad tot vaststelling van normen voor de opvang van verzoekers om internationale bescherming (herschikking), 10 maart 2017, C 75/97, 1.1.6. en 1.4.7.

293 Europees Parlement, Verslag over het voorstel voor een richtlijn van het Europees Parlement en de Raad tot vaststelling van normen voor de opvang van verzoekers om internationale bescherming (herschikking), 10 mei 2017, A8-0186/2017, amendementen 64 en 67

294 Ibidem, amendement 70.

295 Zie bijvoorbeeld nieuwsberichten als: Knack, 'Plannen opsluiten migrantengezinnen: Francken verdedigt zich tegen Raad van Europa', Knack, 14 juni 2018, https://www.knack.be/nieuws/belgie/plannen-opsluiten-migrantengezinnen-franckenverdedigt-zich-tegen-raad-van-europa/article-normal-1160871.html.

296 AIDA Country Report Belgium: 2018 update, maart 2019, 97; AIDA Country Report France: 2018 update, maart 2019, 99; AIDA Country Report Greece: 2018 update, maart 2019, 158; AIDA Country Report Ireland: 2018 update, februari 2019, 76; AIDA Country Report Italy: 2017 update, maart 2018, 106; AIDA Country Report Netherlands: 2018 update, maart 2019, 73; AIDA Country Report Poland: 2018 update, maart 2019, 65; AIDA Country Report Portugal: 2017 update, maart 2018, 90.

297 Zie ook: Europese Commissie, Voorstel voor een richtlijn van het Europees Parlement en de Raad, tot vaststelling van minimumnormen voor de opvang van asielzoekers in de lidstaten (herschikking), 3 december 2008, COM(2008) 815 final, 24.

298 ECRE, Comments on the Commission Proposal to recast the Reception Conditions Directive (Com (2016) 465), oktober 2016, 13; Europees Economisch en Sociaal Comité (EESC), Advies over het voorstel voor een richtlijn van het Europees Parlement en de Raad tot vaststelling van normen voor de opvang van verzoekers om internationale bescherming (herschikking), 10 maart 2017, C 75/97, 1.1.6. en 1.4.7.

299 C. Smyth, 'Is the right of the child to liberty safeguarded in the common European Asylum System?', European Journal of Migration and Law 15, 2013, 135. 